\author{
UNIVERSIDADE DE SÃO PAULO \\ ESCOLA DE COMUNICAÇÕES E ARTES \\ DEPARTAMENTO DE COMUNICAÇÕES E ARTES
}

BIBLIÓFILOS AUDIOVISUAIS: OS MEDIA COMO FORMA DE APROXIMAR ESTUDANTES DOS LIVROS

ROGÉRIO PELIZZARI DE ANDRADE 


\author{
UNIVERSIDADE DE SÃO PAULO \\ ESCOLA DE COMUNICAÇÕES E ARTES \\ DEPARTAMENTO DE COMUNICAÇÕES E ARTES
}

\title{
BIBLIÓFILOS AUDIOVISUAIS: OS MEDIA COMO FORMA DE APROXIMAR ESTUDANTES DOS LIVROS
}

\author{
ROGÉRIO PELIZZARI DE ANDRADE
}

\begin{abstract}
Dissertação apresentada junto ao departamento de Comunicações e Artes da USP como requisito parcial para a obtenção do título de Mestre em Ciências da Comunicação, área de concentração Interfaces Sociais da Comunicação, linha de pesquisa Educomunicação.
\end{abstract}

Orientador: Prof. Dr. Adilson Odair Citelli

São Paulo, 2011 
A Sandra Regina 
BANCA EXAMINADORA - SÃO PAULO, 2011 


\section{AGRADECIMENTOS}

Ao professor Adilson pela paciência, por me reconduzir ao caminho da lucidez nos momentos de catarse, mas também por contribuir com os descaminhos; às professoras Neide e Sandra por terem aceitado participar da minha banca e pelas críticas que deram nova perspectiva a este trabalho; aos professores da Escola Celso Leite Ribeiro Filho, em especial à diretora Rosimeire, à assistente de direção Aparecida e ao professor de sala de leitura Eduardo, que não só me acolheram como também foram prestativos durante todo o percurso da pesquisa de campo; aos colegas de grupo de estudos em comunicação e educação Ana Luisa, Eliana, Helena, Lisa, Maria do Carmo, Michel e Sandra pelos textos trocados, pelas calorosas discussões e pelas palavras de apoio nos momentos de dificuldade; aos alunos da disciplina Teorias da Comunicação que ministro na FIAM e seus incontáveis questionamentos pertinentes, que, sem que eles soubessem, muitas vezes completavam capítulos que pareciam sem soluções; a Ana, que trabalhou muito na revisão da monografia, deu ótimas ideias e foi determinante na reta final deste percurso; a Humberto, companheiro das caminhadas aos domingos pela manhã com quem buscava pelo percurso teórico, epistemológico e metodológico perfeito; aos meus pais pelo apoio e pela compreensão diante das longas ausências e dos períodos em que fui econômico com as palavras; a Hanna pelas lambidas consoladoras; a Minduim por comer todos os meus sapatos e por me fazer esquecer momentaneamente da batalha; e especialmente a Sandra, que acompanhou todos e cada um destes momentos, com destaque aos períodos críticos (que não foram poucos), sem jamais deixar de me apoiar e a quem, sem dúvida, devo todas as palavras que fazem parte desta dissertação de mestrado. 


\section{RESUMO}

Os meios de comunicação eletrônicos são responsabilizados por supostos desvios das práticas leitoras. Influenciados pelas teorias críticas da comunicação, especialmente ligadas à Escola de Frankfurt, pesquisadores afirmam que os media representam o principal impedimento para que os jovens se aproximem dos livros. Os estímulos audiovisuais de suportes, como a televisão, o rádio, a internet e o videogame, em geral marcados pela superficialidade e pela tentativa de induzir as audiências ao consumo, minimizariam o contato com vivências mais complexas que se manifestam no contato com o texto impresso. Propondo uma inversão deste ponto de vista, uma pesquisa etnográfica foi realizada em sala de leitura de uma escola municipal de São Paulo. O objetivo era identificar relações entre as experiências vivenciadas com os produtos midiáticos e o possível interesse que eles podem despertar em relação aos livros. Alinhado com autores como MartínBarbero, Canclini e Orozco, que consideram a possibilidade de utilização dos meios de comunicação para contribuir com o processo de educação, o percurso teórico do estudo abrangeu ainda uma revisão das teorias críticas, ideias acerca da função e do conceito de leitura e a influência dos fatores culturais neste processo.

\section{PALAVRAS-CHAVE}

Comunicação; Educação; Livro; Leitura; Medias; Salas de Leitura 


\begin{abstract}
The electronic communication media are responsible for supposed challenges to reading practices. Influenced by critical communication theories, particularly those linked to the Frankfurt School, researchers affirm that the media represent the main barrier between youth and books. Audiovisual support stimuli, such as television, radio, the internet and videogames, marked in general by superficiality and attempts to induce audiences to consumption, would minimize contact with more complex experiences that are manifest in contact with the printed word. Proposing a reversal of this perspective, an ethnographic study was conducted in a reading room of a São Paulo municipal school. The purpose was to identify relationships between experiences with media products and the possible interest in books that they may stimulate. Aligned with authors such as Martín-Barbero, Canclini and Orozco, who consider the possible use of communication media to contribute to education, the theoretical route of the study also included a review of the critical theories, ideas about the function and concept of reading and the influence of cultural factors in this process.
\end{abstract}

\title{
KEY WORDS
}

Communication; Education; Book; Reading; Medias; Reading Rooms 


\section{Sumário}

1. INTRODUÇÃO ...................................................................................................9

2. PRIMEIRAS PALAVRAS ...........................................................................19

3. PROBLEMA E OBJETIVOS DE PESQUISA................................................25

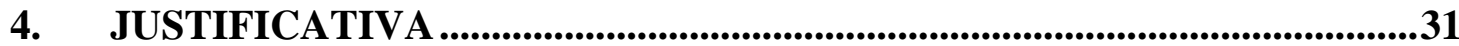

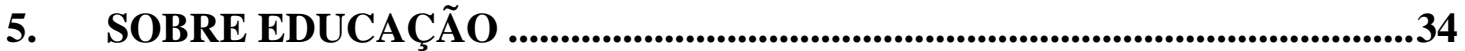

6. LEITURA E NOVAS LEITURAS.............................................................40

6.1 Leituras midiáticas ................................................................................................43

7. CORRENTES CRÍTICAS: MEIOS DE COMUNICAÇÃO E A

LEITURA DE LIVROS................................................................................48

7.1 Primeiras críticas..................................................................................................49

7.2 Críticas atuais ...............................................................................................58

8. MEIOS DE COMUNICAÇÃO E OPORTUNIDADES DE LEITURA........63

9. LIVROS AINDA? POR QUÊ? ......................................................................70

10. METODOLOGIA DE PESQUISA .................................................................78

10.1 Amostragem ....................................................................................................82

10.2 Técnicas de pesquisa .....................................................................................84

11. LEVANTAMENTO E ANÁLISE DE DADOS ..............................................88

11.1 Resgate histórico do Programa Sala de Leitura - Critérios e caminhos ..........................................................................................................................88

11.2 As salas de leitura e os media: um percurso de idas e vindas.....................89

11.3 Escola Municipal Celso Leite Ribeiro Filho - Olhar de Fora ......................96

11.4 Olhar de dentro ............................................................................................107

11.4.1 A Sala de Leitura da Escola Celso Leite Ribeiro Filho ............................111

11.5 Um trabalho de observação ...........................................................................118

11.5.1 Plano geral..................................................................................................121

11.5.2 Plano específico............................................................................................128

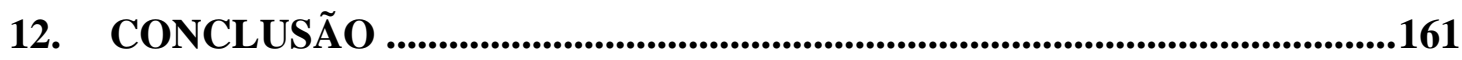

13. REFERÊNCIA BIBLIOGRÁFICA.............................................................168 


\section{INTRODUÇÃO}

É estranho pensar que introduzir é voltar ao começo e não efetivamente começar. Após um ponto final, que, no fundo, nem final é, revemos, repassamos e acabamos por fazer remissão a outros e muitos começos, na tentativa de organizar e ordenar fatos, ideias. E se introduzir vem depois do último ponto ou rigorosamente aceitamos que o derradeiro sinal ocorre ali, após as páginas iniciais, o que sugere pela estrutura formal do documento que ele (o ponto) está fora do lugar, temos a impressão de que há, em verdade, muitos fins, incontáveis começos e outros tantos meios.

A tentativa de estabelecer um encadeamento histórico, que dê sentido e que faça as vezes de percurso, parece-nos muito mais uma forma de colocar ordem no caos que é a sucessão (e paralelismo) de acontecimentos. Ou como sinaliza Foucault, trata-se de entender o passado para explicar o presente, preferencialmente a partir de uma arqueologia que abarca não apenas discursivamente o encadeamento de fatos, mas uma espécie de história das práticas.

Talvez seja por concordar com este posicionamento que 21 Gramas é um filme que me ${ }^{1}$ atrai tanto. Ao deturpar a ideia de linearidade, o diretor do filme, Alejandro Gonzáles Iñarritu, retrata as personagens vividas pelos atores Sean Penn, Benicio Del Toro e Naomi Watts, em suas vidas individuais, paralelas e conjuntas, sem qualquer tipo de organização temporal. Há sequência de imagens, mas ela não acompanha uma cronologia, ainda que seja parcial, nem obedece a outras lógicas de organização das cenas, como quando a história é contada de trás para frente.

O que prevalece são as práticas, a profusão de experiências, de dores, de sensações entrecortadas, suficientes para que o leitor organize, por si mesmo, a trajetória do trio: Paul (Penn) está na fila para o transplante do coração e recebe o órgão do marido de Cristina (Watts), morto em um atropelamento causado pelo ex-

\footnotetext{
1 Tendo em vista que a partir deste trecho faremos um pequeno relato de experiências pessoais, achamos (ou achei) conveniente pessoalizar a descrição.
} 
presidiário e convertido a cristão fervoroso Jack (Del Toro). Paul se apaixona por Cristina, que, incapaz de se recuperar da sua tragédia particular, quer que ele mate Jack, agora um cético, que abandonou a família para viver praticamente isolado do convívio social.

Ao pensar nos diferentes caminhos que me levaram a, em algum momento, escolher este tema para o projeto de mestrado e nos outros tantos que foram percorridos para desenvolvê-lo, aprimorá-lo e, por muitas vezes, desviá-lo de sua intenção original, sou tentado a estabelecer um encadeamento lógico de acontecimentos e vivências que pudessem dar um sentido à minha epopeia. Prefiro, entretanto, tentar elencar, à maneira bruta de Iñarritu, sem perder de vista o modo de entender a história proposto por Foucault, momentos e situações que, a meu ver, determinaram de forma significativa esta jornada, inclusive com mudanças substanciais de última hora, com abalos em antigos valores e crenças.

Lembro-me daquela que para mim poderia ser uma primeira experiência real com os livros. Voltava com minha mãe, aos três anos, de um passeio ao centro da cidade. No ônibus, no banco alto que toda criança gosta de andar, estava eu com a cara enfiada num livro sobre Krishna que minha mãe havia comprado de um adepto da religião. Eu não conhecia ainda os símbolos e significados do texto impresso e, como se ausentavam das páginas as clamadas figuras que os ávidos olhinhos procuravam, eles simplesmente percorriam as linhas incompreensíveis. E na repetição dos gestos dos adultos que eu observava no momento em que se dedicavam à leitura, de tempos em tempos, as páginas eram por mim viradas.

Uma moça, que acompanhava a cena atentamente, não se conteve diante do prodígio em potencial. “Esse menino já sabe ler?” Minha mãe, com a sinceridade que é só dela, acabou com todas as minhas esperanças de me passar por gênio. “Não, ele está só brincando.”

O garoto que sentia fascínio pelos livros e associava o acesso a eles a uma forma de se tornar inteligente descobriu mais de duas décadas depois que aquela tentativa já era leitura. A ânsia por descobrir o sentido daqueles sinais revelaria uma das múltiplas apropriações que este contato entre leitor e obra permite. 
Quatro dias antes de elaborar as linhas lidas neste momento, fugi por algumas horas do desgaste que marca a conclusão do trabalho monográfico para visitar uma exposição temporária no museu Lasar Segall. Intitulada Além da biblioteca, consistia em um conjunto de obras que utilizaram o livro como objeto. Evidenciadas a partir de dois aspectos (forma e conteúdo), as peças assumiam estruturas variadas. Coleções antigas, formas esculpidas no interior de um título, vários exemplares organizados de maneira a compor uma escultura, fotos de livros, livros que não podiam ser abertos por terem sido encadernados dos dois lados.

Na exposição, as possibilidades de leitura, que já são inúmeras, multiplicaram-se algumas vezes mais. A leitura do autor da obra literária, a leitura do leitor da obra literária, a leitura do artista plástico sobre a obra literária, a leitura do leitor da leitura do artista plástico sobre a obra literária.

Em um momento anterior desta trajetória, no primeiro semestre de 2008, depois de alguns dias arrecadando doações, enchi a caçamba de uma picape e segui para Pradínia, distrito da pequena cidade de Pirajuí, onde mora parte da minha família. Algo que realmente me surpreendeu nesta viagem foi o fato de que, mesmo vivendo em situação precária e com poucos recursos para comprar artigos básicos, como roupas, além das mínimas condições de moradia - doze pessoas ocupavam uma casa de aproximadamente cinquenta metros quadrados e sem reboco -, eles tinham acesso a aparatos tecnológicos de comunicação. Uma pequena TV e dois rádios, aparelhos celulares com acesso à internet e câmera, sem contar a visível familiaridade com as linguagens próprias deste universo.

Em dado momento, um dos meus primos, após vencer a timidez inicial do encontro, pediu que a irmã tirasse uma foto nossa e em seguida perguntou se o meu celular tinha tecnologia bluetooth. Diante da negativa, pediu meu e-mail. "Não tem problema. Quando você chegar em casa, consulte sua caixa de mensagem que vai estar lá.”

Meu primo tem vinte anos, estudou até a quarta série e foi obrigado a abandonar a escola para trabalhar. Tem visível dificuldade para ler um texto, por exemplo, mas revelou destreza para lidar com as linguagens midiáticas. 
Mais um salto no tempo e resgato dois momentos distintos em que tive a oportunidade de participar de grandes projetos ligados à área de educação. O primeiro deles, em 2004, na Fundação para o Desenvolvimento da Educação (FDE), ligada à Secretaria da Educação do Estado de São Paulo, e o segundo, em 2007, na Coordenadoria Geral dos Núcleos de Ação Educativa (CONAE).

Entre as incontáveis experiências vividas, uma das que mais me chamou a atenção naquele período foram os inúmeros casos de educadores desviados de suas funções originais. Professores com largo conhecimento e décadas de prática docente desestimulados com as políticas de ensino, com o plano de carreira, com as mudanças no perfil dos alunos, aguardavam o tempo que faltava para a aposentadoria trabalhando como secretários, auxiliares de escritório e contínuos.

Na segunda fase, já na CONAE, tive o primeiro contato com as salas de leitura. Conheci e conversei com professores, participei de treinamentos, acompanhei aulas e estive em algumas unidades escolares para observar os diferentes formatos e características destes espaços.

Fatos inicialmente desligados uns dos outros, assim relatados com a intenção de preservar o que há de descontinuidade entre eles, foram para mim, em períodos igualmente indeterminados, fundamentais para o direcionamento do projeto que desenvolvi nos últimos três anos, nos diversos ângulos: (1) o interesse particular pelos livros e pelas múltiplas possibilidades de leitura; (2) a percepção de que os meios de comunicação estão cada vez mais presentes na vida das pessoas, em todas as classes sociais, representam formas de interação e possuem uma linguagem particular; (3) a hipótese de que os media podem de alguma forma aproximar as pessoas dos livros; (4) a utilização das salas de leitura das escolas municipais da cidade de São Paulo como meio para verificar se a veracidade das suposições se confirmariam.

Os quatro elementos citados e a interação entre eles representam os pilares do trabalho ao qual as próximas páginas dão acesso. E tendo em vista a confessa dificuldade em precisar o tempo, além da intensidade com que estas e outras vivências pessoais se manifestaram, atribuo naturalmente aos desafios estabelecidos 
pela vida acadêmica, em geral, e à pesquisa científica, em particular, a possibilidade de sistematização destas ideias.

A experiência do mestrado, contudo, não representou somente o caminho da ordem e da racionalização. Em outro sentido, ela teve como consequência também a expansão de ideias e, no limite, a ampliação das intercorrências. As disciplinas, os contatos com os professores e colegas, além da descoberta de autores e textos, representaram, por um lado, o enriquecimento intelectual, a formulação, o aprimoramento e alinhamento com determinados conceitos. Por outro, a subversão de premissas, algumas delas determinantes no momento em que decidi estudar a possível relação entre meios de comunicação e leitura.

Muitos momentos, sobretudo durante a realização do trabalho de campo, foram marcados pela incerteza. Eu temia que pudesse estar abrindo mão da vigília mencionada por Bourdieu e frequentemente me perguntava sobre como meu projeto estava sendo conduzido: com que olhar realizo o trabalho de campo? Que critérios utilizo para selecionar autores, textos e trechos de obras? Que tipo de esclarecimento eu realmente obtive em relação a determinados conceitos? Tais ideias que utilizo em certas passagens realmente me convencem?

Em períodos específicos, se transformou em obsessão. Passei a procurar obras que de alguma forma pudessem responder a tais angústias. Em Esboço de auto-análise, de Bourdieu (2010), buscava, evidentemente guardadas as devidas proporções, encontrar similaridades em relação às incertezas, algo que pudesse representar uma espécie de terapia literária. Em O livro negro da psicanálise, organizado por Meyer (2011), investi na tentativa de encontrar algum dos desvios dos quais os inúmeros autores acusavam os teóricos da psicanálise.

Sem perder de vista tais indagações, investi em leituras menos conceituais, que não tivessem exatamente uma abordagem teórica. O livreiro do Alemão, de Junior (2011), representou a procura de casos reais em que os livros teriam transformado a vida das pessoas.

Recorri também às obras literárias: a loucura que tomou conta da personagem principal de Dom Quixote; a vergonha de Hanna, em O Leitor, que 
preferiu ser condenada por crimes de guerra que não cometeu a admitir ser analfabeta; O falecido Mattia Pascal, de Pirandelo (2010), cujo herói, em sua experiência como bibliotecário, constata que só os ratos literalmente devoravam o acervo disponível.

Realizei ainda incursões por filmes de alguma forma ligados ao tema. Por influência de Coli, que na orelha de um livro de Todorov (2010), mencionou Fahrenheit 451, de Truffault ${ }^{2}$, e os bombeiros cuja função era prender as pessoas que se dedicavam ao crime da leitura e incendiar os acervos existentes. No blockbuster O livro de Eli, de Albert Hughes e Allen Hughes, conhecer o mundo depois do fim do mundo, onde quase ninguém sabe ler e, por conta disso, as pessoas teriam a capacidade imaginativa reduzida por ignorarem elementos como a metáfora.

O contato com $O$ livro de Eli e o fim da imaginação me fez resgatar e, portanto, fazer uma releitura de Willian Ospina (2002), que, em seu La decadencia de los dragones, sugere um marco do passado em que teria havido a aniquilação da fantasia, do universo imaginário e intuitivo frente à ascensão da objetividade científica e à valorização do dado concreto. Até Miguel de Cervantes e seu Dom Quixote, convivíamos com dragões, a magia, a mitologia fantástica e a imortalidade. Poderíamos ser vistos montados em cavalos alados, lançando bolas de fogo contra inimigos das trevas e atravessando pântanos assombrados atrás da chama da vida eterna.

Dom Quixote teria colocado fim aos nossos devaneios de criança. Por culpa dele, crescemos. Fomos informados de que os gigantes na verdade não passam de moinhos de vento, de que escudeiros são simples lavradores, de que a princesa é uma "mera” camponesa e de que nunca existiram cavaleiros, apenas fidalgos amalucados. A grande fogueira teria nos ajudado a esclarecer as coisas. Sobrinha, padre-cura e barbeiro. Aprendemos a evitar os sonhos quando estamos na companhia dos acordados. Olhos bem abertos.

\footnotetext{
${ }^{2}$ Aliás, vejo momentos como estes como alguns dos melhores que a leitura pode proporcionar. Ao ler um autor (Todorov), descubro que outro (Coli) cita um terceiro (Truffault), que elaborou um filme (Fahrenheit 451). Pelo menos, três leituras em uma.
} 
Envolvi, por fim, neste movimento entre diferentes abordagens relacionadas ao tema, que trafegava da ficção à teoria e da teoria à ficção, um terceiro elementos. Tratei de levantar pesquisas científicas que de alguma forma pudessem contribuir com os interesses desta dissertação.

Descobri um trabalho realizado por Michèle Petit (2009), no início dos anos 1990, quando ela teria iniciado estudos que envolvem a escrita, a leitura e o lugar do leitor. Partindo de experiências pessoais, principalmente diálogos constantes com leitores, mediadores de leitura, bibliotecários, professores, psicanalistas, escritores e animadores culturais de várias partes do mundo, ela revela vivências de leituras compartilhadas, desenvolvidas em regiões afetadas por conflitos armados, desequilíbrio social, migrações populacionais forçadas ou acentuada deterioração das condições de vida.

Tive acesso a uma série de outros autores que, de alguma forma, influenciaram o desenrolar do presente trabalho. Questões como propostas metodológicas de aperfeiçoamento da aprendizagem da leitura em Almeida (1987) e Tiosso (1990); as relações estabelecidas entre os alunos e a biblioteca escolar em Magalhães (1992); o desenvolvimento de habilidades de leitura e escrita presentes em Toschi (1989); como se manifestam os interesses dos alunos pela leitura em Oliveira (1972); a leitura oral na escola em Souza (1991); a associação entre atividades lúdicas e o interesse pelos livros em Rosamilha (1978); e a prática da leitura criativa e crítica na escola em Hussein (1982).

Durante a pesquisa foram recuperados dois estudos que tratam especificamente da Sala de Leitura. Em realidade, foram os únicos identificados ao longo do levantamento que abordavam estritamente o projeto desenvolvido pela Prefeitura do Município de São Paulo. O primeiro deles, de autoria de Piovesan (1999), revela o entendimento de que, não raro, os professores orientadores das salas de leitura não compreendem a extensão nem as características de suas funções no que diz respeito à relação do aluno com o livro. Neste contexto, a autora desenvolveu um trabalho que envolve a recuperação e análise da legislação que trata sobre o tema e acompanhou as atividades realizadas durante estas aulas. 
Mendes (2006), por sua vez, ainda que tenha partido de uma perspectiva mais ou menos parecida, defendeu a tese de que o projeto Sala de Leitura é uma inovação que se mantém apesar da descontinuidade política. A partir de um minucioso resgate da história do programa, a autora analisou toda a trajetória, ao longo de três décadas, com o objetivo de validar a hipótese que passa pela relação entre escola e cultura.

Percorridos os caminhos expostos acima, os doze capítulos que compõem esta monografia certamente são uma das infinitas possibilidades de organização desta profusão de fatos, momentos, oportunidades, reflexões e contatos. Ao retomálos, observo como estes acontecimentos permitiram que o indeterminado se transformasse em palavras, linhas e parágrafos, mas também posso visualizar, como se a dissertação fosse uma espécie de caleidoscópio, alguns dos outros tantos formatos que não foram, embora pudessem ter sido.

O Capítulo II aborda a leitura de livros no Brasil a partir de uma perspectiva histórica e apresenta também estudos desenvolvidos recentemente acerca da prática leitora, sobretudo entre os jovens, bem como as associações promovidas entre esta e os meios de comunicação.

Os Capítulos III, IV e V tratam da delimitação dos objetivos e dos fatores que motivaram a realização da pesquisa. Eles se voltam para a especificação do objeto, qual seja o tipo de leitura que inspirou o trabalho, a inter-relação entre meios de comunicação, educação e leitura e o que justificaria compreender essa interação.

O Capítulo VI apresenta conceitos de leitura e as transformações que os media provocaram nesta prática. As chamadas leituras híbridas, que envolvem diferentes linguagens, como aquelas que são próprias ao rádio, à televisão e ao livro.

O Capítulo VII retoma estudiosos contrários aos meios de comunicação, com destaque para a Escola de Frankfurt, e aponta alguns dos trabalhos produzidos recentemente que seguem o mesmo princípio. 
Em sentido inverso, o Capítulo VIII está focado não apenas na exposição de ideias elaboradas pelos entusiastas das novas tecnologias. Ele também é dedicado às reflexões que dão conta do papel e da importância das experiências individuais e das identidades na constituição do comportamento social. Neste sentido, são retratados os estudos culturais e os pensadores de origem latino-americana que estabelecem relação entre comunicação e educação.

A proposta do Capítulo IX é apresentar argumentos para a manutenção e a valorização da leitura de livros como meio de aquisição de conhecimento, desenvolvimento da capacidade intelectual e estímulo à imaginação. Ele explora o entendimento de que as novas demandas sociais não representam incompatibilidade com a cultura letrada.

Os Capítulos X, XI e XII retratam, respectivamente, a metodologia aplicada na pesquisa de campo, a captação e análise dos dados e as conclusões obtidas por meio desta atividade reflexiva. Tendo em vista as necessidades apresentadas pelo estudo, a etnografia foi escolhida como forma de responder ao problema e aos objetivos de pesquisa. Para tanto, a observação participante foi eleita como principal instrumento de levantamento de informações e foi aplicada junto a alunos do $9^{\circ}$ ano do ensino fundamental que frequentavam a sala de leitura da escola municipal Celso Leite Ribeiro Filho.

Relendo os sete parágrafos que antecedem a este e que têm a missão de explicar o que virá daqui por diante, sinto que esta maneira organizada de apresentação poderia sugerir certa aproximação com aquela noção de cronologia mencionada nos primeiros parágrafos. Como se a forma de exposição fosse o reflexo de uma caminhada homogênea, segura, sem desencontros. Ou como se em algum momento, em virtude dos possíveis esclarecimentos e da melhor estruturação de conceitos e reflexões, tal racionalização pudesse ter sido alcançada.

Ao contrário, percebi, a certa altura deste (des)caminho, que as descobertas e os encontros diários com os potenciais apaziguadores das minhas aflições geravam outras e múltiplas formas de incertezas. Agora mesmo, entre rascunhos e páginas impressas, livros abertos, anotações, estou acompanhado da insegurança e 
dos temores que me cercavam em 2008, quando sentei pela primeira vez na tentativa de transformar algumas ideias soltas em um projeto de pesquisa.

Sigo errante como o cavaleiro. Com um punhado de livros na cabeça, no trote constante do cavalo Rocinante, ando por caminhos incertos, com o auxílio providencial das estrelas. 


\section{PRIMEIRAS PALAVRAS}

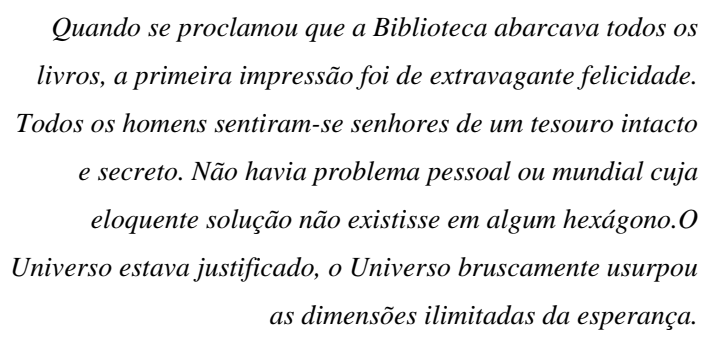

(A Biblioteca de Babel, Jorge Luís Borges)

O presente projeto de pesquisa tem por objetivo verificar se os meios de comunicação, especialmente os audiovisuais, podem contribuir para aproximar os jovens dos livros. Partindo de visão contrária às correntes críticas, especialmente identificadas com a Escola de Frankfurt, que responsabiliza a cultura de massa pelo desinteresse pelas práticas leitoras, buscamos encontrar possíveis pontos de convergência entre as obras impressas e os media.

As origens da falta de interesse e de investimento em educação no país remetem ao período colonial. Em Raízes do Brasil, Sérgio Buarque de Holanda (1997) estabelece uma estreita relação entre o menosprezo dos portugueses pela formação cultural do anexo deste lado do Atlântico e nossa evolução social. Ao traçar um paralelo entre a "Vida Intelectual na América Espanhola e no Brasil", o autor demonstra o quão distantes eram as realidades dos dois países. Entre 1775 e 1821, 720 brasileiros se graduaram e, assim mesmo, na Universidade de Coimbra. No México, que no mesmo período já contava com escolas de ensino superior, havia quase 8 mil bacharéis e pouco menos de 500 doutores licenciados.

A identificação tardia de que a consolidação de um sistema de ensino nacional deveria estar entre as prioridades do país resultou naquilo que poderíamos classificar como uma espécie de “queima de etapa”. É possível que esta seja uma das razões para que países como o Brasil, conforme observam autores como Citelli, tenham passado diretamente de uma sociedade oral para audiovisual. 
“Forjados na dinâmica da expansão colonial e vivendo o estatuto da periferia, muitos países latino-americanos apresentaram uma particularidade quanto à sua história cultural: passaram rapidamente do plano discursivo-verbal para os dos meios audiovisuais. O livro, a escrita e a alfabetização - no sentido estrito do letramento - como sinônimo de todo o saber e traço distintivo nas relações sociais não tiveram tempo de assentar-se $e$ democratizar-se antes da entrada massiva das tecnologias das imagens e da retransmissão sonora." (CITELLI, 2004:148)

Em outras partes do mundo, sobretudo na Europa, a cultura letrada se disseminou graças à revolução industrial. Apesar de calcada em uma visão pragmática da educação, por intermédio da qual aquilo que seria ensinado deveria necessariamente ter uma finalidade instrumental e servir a um ofício, as sociedades se alfabetizaram rapidamente e, muito antes que a primeira película fosse projetada na sala escura e que ocorressem as transmissões radiofônicas inaugurais, os jornais populares já eram consumidos pela maioria daquelas sociedades.

O próprio surgimento do romance-folhetim, na década de 1830, contribuiu para a aceleração deste processo. Nascido na França, na esteira do ideal burguês, ele tinha o propósito de democratizar o jornal, torná-lo mais barato e acessível à população (MEYER, 1996). Ao abordar assuntos considerados mais “leves”, com as histórias de rodapé, rapidamente ganhou adeptos entre as camadas economicamente menos favorecidas.

O Brasil não acompanhou este fenômeno de alfabetização ${ }^{3}$, que se estendeu por todo o continente Europeu, América do Norte e alguns países da América Espanhola. Em parte pela distância do epicentro do mundo à época, em parte pelos resquícios da colonização do tipo exploratória e em parte pelas atividades econômicas do país, a maioria delas oferecendo oportunidades de trabalho manual e

\footnotetext{
${ }^{3}$ Cabe salientar que o conceito utilizado aqui está ligado diretamente à cultura letrada. Ou seja, refere-se à “alfabetização” por intermédio da qual se desenvolve-se a capacidade de ler o texto impresso, a palavra escrita.
} 
que não exigiam habilidades específicas, o fato é que as primeiras discussões acerca da instituição de um sistema de ensino universal começou a ser feita apenas no decorrer do século XX.

“A dominação das mídias eletrônicas, sem terem sido experimentados os fenômenos de escolarização coletiva,organização do público leitor e divulgação da leitura” (ZILBERMAN, 1988:9), associada aos problemas econômicos que historicamente perseguem o país e em conjunto com o desinteresse de sucessivos governos pela educação desde o período colonial, tiveram como consequência déficits que ainda hoje influenciam as estatísticas oficiais.

Instituto Nacional de Alfabetização Funcional (INAF) ${ }^{4}$, com medição anual, é uma das referências mais atualizadas no assunto. Dirigido à população com idade entre 15 e 64 anos, mede as habilidades e práticas de leitura e escrita e, em síntese, estabelece quatro categorias classificatórias. O último levantamento publicado, referente a 2009, sinaliza a seguinte distribuição: 7\% dos brasileiros são analfabetos; 30\% alfabetizados em nível rudimentar, 37\% alfabetizados no nível básico e outros 26\% têm domínio pleno da habilidade de leitura.

Outra pesquisa realizada regularmente, mas que envolve diferentes países, é o Programa Internacional de Avaliação do Estudante (PISA) ${ }^{5}$. Coordenado pela Organização para a Cooperação e Desenvolvimento Econômico (OCDE), é um levantamento por amostragem que mede, entre outras coisas, a habilidade e a proficiência em leitura. Um dos 34 membros oficiais da OCDE, o Brasil participou das quatro edições do levantamento, que teve início em 2001. Ao longo deste período - e apesar das flutuações -, o indicador do país apontou melhoras, saltando de 396, na primeira medição, para 412 pontos em 2009.

Atualmente ocupamos a $53^{\mathrm{a}}$ posição no ranking do instituição, que reúne um total de 64 avaliados. Estamos atrás de países como Chile, Bulgária, Colômbia, México, Romênia, Tailândia e Uruguai.

\footnotetext{
${ }^{4}$ Acessado em http://www.ipm.org.br/ipmb_pagina.php?mpg=4.02.02.00.00\&ver=por no dia 3 de julho de 2011.

${ }^{5}$ Acessado em http://www.pisa.oecd.org/pages/0,2987,en_32252351_32235731_1_1_1_1_1,00.html no dia 3 de julho de 2011.
} 
Em âmbito nacional, um amplo trabalho, que deu origem ao livro Retratos da Leitura no Brasil, também promoveu pesquisas em dois momentos distintos (2000 e 2006), mas a partir de bases e referências diferentes, o que impossibilita comparações. Como sinaliza o organizador da obra, Galeno Amorim, a última edição do estudo tinha como finalidade “diagnosticar e medir o comportamento leitor da população, especialmente em relação aos livros, mas sem deixar de analisar outros suportes, como os jornais, revistas, histórias em quadrinhos, livros digitais, audiolivros” (2008:36), entre outros.

Os resultados da pesquisa revelam que os brasileiros leem em média 4,7 livros por ano, mas destes apenas 1,3 é lido fora da escola. Em faixas etárias como dos 11 aos 13 anos, esse número alcança 8,5 livros, com apenas 1,4 não relacionados às necessidades e indicações do sistema de educação.

Alguns elementos identificados no trabalho interessam diretamente à nossa pesquisa e podem representar indícios de que, de fato, o comportamento leitor das novas gerações é influenciado pela cultura dos media. Por exemplo, mais da metade dos entrevistados (55\%) diz que costuma ler apenas trechos ou capítulos de livro, praticando uma espécie de zapping leitor. Um quarto das crianças entre 5 e 13 anos gosta de ler com a televisão ligada. As pessoas que têm acesso à internet dedicam mais horas lendo textos publicados nesta plataforma (2h24min) do que aos livros (1h56min) e 25\% dos entrevistados afirmam que publicidade e críticas ou resenhas influenciam no processo de escolha de um livro.

Instituições privadas também têm divulgado estudos, séries de reportagens e equivalentes, mas a partir de uma visão otimista sobre o assunto. A capa da edição de 18 de maio de 2011 da revista Veja traz um longo título sobre o crescimento da quantidade de leitores no Brasil. A tônica da matéria, além dos velhos clichês sobre a importância de se desenvolver o hábito, as oportunidades de emprego decorrentes, etc., era o sucesso da literatura voltada para o público jovem, que, segundo os números das editoras, seriam os grandes impulsionadores das vendas. O surgimento de blogs sobre títulos e séries, que aglutinam leitores e pautam novos lançamentos, seria apenas uma das razões para as vendas de livros como Harry Potter e Crepúsculo, que atingem a casa dos 3 milhões e 5,5 milhões respectivamente. (MEIER, 2011:102) 
O jornal Meio \& Mensagem de 23 de maio de 2011 revela que o faturamento do mercado de livro, será, no mesmo ano, da ordem dos $\mathrm{R} \$ 7,1$ bilhões, em um total de 340 milhões de exemplares vendidos. O crescimento, segundo a publicação, só será possível graças à expansão dos gastos com livros na última década nas classes $\mathrm{D}$ e $\mathrm{E}$, que tiveram um incremento de 4,97 vezes. (CASTELLÓN e RIBEIRO, 2011:23)

Ademais, observa-se que boa parte das tecnologias de comunicação utilizadas atualmente foi desenvolvida de maneira a estimular maior interatividade com a palavra escrita: os serviços disponibilizados na internet, como os sítios, os blogs, o Facebook, o Orkut, o Twitter e até mesmo os chats; os complexos jogos de viodeogame, em que os participantes tem de acompanhar pistas e, não raro, consultar verdadeiros manuais para poder superar os obstáculos; e até mesmo as mensagens nos aparelhos celulares.

Aliar as múltiplas formas existentes de interação com tais aparatos, favorecem a aproximação dos usuários com a palavra escrita, seria um dos possíveis caminhos para o desenvolvimento do comportamento leitor. Em outras palavras, seria conveniente/proveitoso verificar formas de utilização dos media a fim de potencializar a aproximação e o interesse pelo livro.

O presente projeto busca se aproximar das pesquisas em comunicação iniciadas a partir dos estudos culturais e, de certa maneira, aprofundadas com o advento das teorias da mediação, com o propósito de encontrar caminhos para enfrentar os desafios da educação, de forma mais específica no âmbito da leitura. Trabalhos que invertem, em certa medida, as tendências do pensamento crítico e apontam para uma relação dialógica/polifônica entre as parte envolvidas no processo de comunicação; propostas que se apoiam no entendimento de que "o essencial da cidadania é o fato de ela estar associada ao 'reconhecimento recíproco'", isto é, "ao direito de existir/contar social" (MARTÍN-BARBERO, 2008:35); e que, apesar de reconhecerem o que os meios de comunicação têm de negativo, sugerem que eles também podem ser utilizados de forma benéfica, como meio útil para se educar e - por que não? - ensinar/estimular a leitura. 
Neste contexto, a pesquisa tem a finalidade de contribuir com os estudos desenvolvidos no decorrer dos últimos anos, no campo da Educomunicação. A ideia é voltar-se especificamente ao tema da leitura de livros e sua inter-relação com os meios de comunicação. A hipótese é de que, em face às novas configurações e demandas sociais, os media poderiam contribuir para realizar tal aproximação, mais diretamente no que diz respeito aos jovens. Em outras palavras, o objetivo é, por intermédio de linguagens que lhes são familiares, buscar elementos nos produtos veiculados pelos meios de comunicação que criem a possibilidade de mediação entre o cotidiano destes jovens e a cultura letrada. 


\section{PROBLEMA E OBJETIVOS DE PESQUISA}

Cabe pontuar ao menos dois pontos que são prioritários para a condução desta pesquisa. Em primeiro lugar, a que tipo de livros nos referimos, qual leitura será objeto do estudo. Em segundo lugar, em quais termos nos basearemos para estabelecer (ou tentar estabelecer) a inter-relação entre meios de comunicação, educação e leitura.

Quanto à primeira variável, é oportuno lembrar que se trata de um termo amplo, passível de generalizações. Mesmo se restrito à esfera da palavra escrita, o vocábulo tende a suscitar uma grande quantidade de possibilidades. Em nosso caso, procuramos preservar inicialmente esta amplitude, utilizando-nos da concepção mais abrangente do livro: ficção, poesia, romance, conto, crônica, técnico, acadêmico, de línguas, enciclopédia. Dito de maneira mais clara, independentemente do gênero, da temática e da função, o tipo de leitura que nos interessa é aquela que se pode realizar por meio de qualquer livro, da palavra impressa.

Já estabelecido o objeto da pesquisa, direcionamos o foco ao que podemos chamar de leitura espontânea. Aquela, portanto, que é destituída de qualquer forma de obrigatoriedade, exigência ou necessidade; que se faz única e exclusivamente por interesse, curiosidade, por vontade própria. Neste sentido, toda e qualquer leitura realizada por razão de prova, exame, teste, avaliação ou equivalente foge, neste momento, ao nosso interesse.

Partimos do pressuposto de que a leitura deve ser uma prática autônoma. Ainda que iniciada, praticada e orientada no universo escolar, tem de estar além dele, como parte do cotidiano, integrada aos hábitos e ao comportamento das pessoas. Ressaltamos a importância desta prática como meio de aquisição de conhecimento, de desenvolvimento de habilidades intelectuais específicas, como o aprimoramento da memória, o estímulo ao raciocínio complexo e de diferentes compreensões do mundo. 
A pesquisa Retratos da Leitura no Brasil indica que os estudantes leem 7,2 livros por ano contra 3,4 lidos pelos não estudantes. Vale destacar que no universo de leituras realizadas pelos primeiros, 5,5 são obras indicadas pela escola.

Sob o ponto de vista da motivação da leitura, como afirma Failla (2009), a perspectiva é de que ocorra uma descontinuidade desta prática tão logo os jovens encerrem seu ciclo na educação formal. Embora a faixa etária entre 5 e 17 leia quatro vezes mais livros por semana se comparada com a população como um todo, deduz-se que o comportamento está associado à obrigatoriedade.

"Mas o fato de estar lendo mais do que a população em geral pode nos indicar que continuará lendo após sair da escola? Se avaliarmos a motivação para a leitura, percebemos que ainda não foram seduzidos para essa prática: entre esses jovens 45\% informam que lê por obrigação, enquanto somente 26\% o fazem por prazer. Esse resultado não nos deixa com muita esperança.” (CITELLI, 2004:148)

A contribuição dos meios de comunicação neste processo se daria no estabelecimento de conexões entre o universo dos jovens e o mundo que eles podem encontrar nas páginas dos livros. A potencialização destas formas de constituição de sentido - se elas existem de fato - seria uma maneira de atingir a mencionada autonomia do leitor, que não mais os procuraria apenas por imposição do currículo escolar ou exigência acadêmica. Assim, o prazer, a vontade de saber, a curiosidade que move tais jovens a procurarem plataformas que utilizam outras linguagens, como o rádio, a televisão, o videogame e a internet, poderiam ser ampliados ou igualmente realizados em relação ao livro, seja ele didático ou de literatura.

Nesta perspectiva, não está entre os objetivos deste trabalho a preocupação em definir livro literário. Definições como alta literatura, paraliteratura e subliteratura não têm relevância para a pesquisa. Utilizamos como referência a argumentação de Abreu, para quem as classificações devem ser observadas com 
cautela, pois abarcar uma quantidade maior de gêneros, bem como de qualidades, "pode favorecer o encontro com a alteridade (alteridade de temas, alteridade de modos de se expressar, alteridade de critérios de avaliação).” (2006:111)

Não se trata de ignorar os cânones ou a cultura erudita, mas sim de despertar o interesse dos leitores tomando-se como referência obras que façam parte da sua realidade e que estejam mais alinhadas aos seus anseios e curiosidades.

Justamente por nos interessarmos de forma particular por esta leitura que denominamos desobrigada, escolhemos como ambiente para a aplicação da pesquisa as salas de leitura da Secretaria Municipal de Educação. Elas são configuradas de maneira a oferecer aulas mais flexíveis e os alunos têm autonomia para escolher aquilo que querem ler.

Nestes ambientes, os estudantes têm maior mobilidade, não precisam estar o tempo todo sentados em suas carteiras, não precisam fazer anotações, não têm de desenvolver análises literárias nem serão avaliados. Simplesmente estão ali para ler, pegar livros emprestados e participar de discussões sobre o tema. Em última instância, as salas de leitura devem estimular uma leitura mais direcionada para os interesses individuais.

Com relação ao papel dos meios de comunicação neste contexto, a finalidade é analisar em que medida colaboram com a possibilidade de aproximar os jovens dos livros por intermédio de leituras que poderíamos classificar como transversais, intersígnicas e híbridas, isto é, que são promovidas a partir da transitoriedade entre diferentes medias e suas linguagens distintas.

O livro O Senhor dos Anéis é um bom exemplo para contextualizar esta ideia. Reorganizado para outros formatos, como o cinema e o videogame, e até mesmo fonte inspiradora de bandas de rock, como Led Zeppelin, ele permite a realização de tais leituras, que perpassam por uma variedade de plataformas.

Vale lembrar que, ao entrar em contato com estes aparatos, os jovens convivem com uma série de temas e assuntos que convergem com suas expectativas. O vídeo no YouTube, que bonito!!! o rap e o rock no rádio, o último lançamento no cinema, o programa de variedades na TV, um jogo sobre a Segunda 
Guerra Mundial no videogame. Cada um destes elementos, por si só, já poderia ser referência para provocar o interesse pelas obras disponíveis no acervo das salas de leitura.

Neste sentido, a presente pesquisa pretende verificar o quanto tais oportunidades são aproveitadas com o propósito de promover a mencionada aproximação. Observar se é possível estabelecer uma correlação entre o nível de interesse dos alunos por determinadas obras e os temas recorrentes nos media. Verificar, de maneira complementar, se os professores procuram estabelecer esta conexão, resgatando temas presentes no cotidiano dos estudantes, que dizem respeito à sua realidade e à vivência comum, se estimulam estas possibilidades diversas de leitura. Em síntese, o estudo tem o foco principal e se direciona, sobretudo, para o aluno, mas, uma vez que o docente é parte integrante deste processo, busca também identificar se eles trabalham nas salas de leitura os temas que frequentam os meios de comunicação tendo em vista o objetivo de aproximar os educandos dos livros.

Canclini (2008) menciona as novas experiências de leitura. O livro aberto, enquanto a música toca no Ipod, a televisão ligada e um amigo virtual chamando pelo Messenger. Leitura feita aos pulos. Atividades paralelas e concomitantes. Entre um parágrafo e outro, entrelinhas, entre palavras. Trata-se de uma experiência leitora bastante diferente daquela verificada 15 ou 20 anos atrás.

Gómez Orozco (2008) fala sobre audiências participativas, em que os leitores não só absorvem, mas também são autores. Consomem, editam, modificam, adaptam as obras. Por intermédio das telas, apropriam-se e redefinem, atribuindo aspectos de suas vivências pessoais ao título original.

Referenciando-nos em tais conceitos, podemos considerar esta leitura transversal ou leitura híbrida, que passa por múltiplas plataformas. Uma leitura que pode ter início, por exemplo, no cinema, ser retomada no videogame e revista no livro. Uma leitura que, por ser dinâmica, talvez contribua para que os jovens se sintam atraídos pelos livros. 
Corroborando a ideia de que a prática leitora tende a se formar de maneira efetiva quando associada a uma prática prazerosa e que os meios de comunicação permitem esta forma lúdica de interatividade, entendemos que este contato, quando intermediado pelos professores, tende a repercutir de maneira positiva.

De forma integrada a este objetivo maior, buscamos, por um lado, observar que tipo de interação se dá na sala de leitura, isto é, se os discursos oriundos da relação com o meio circulam neste ambiente. E, por outro, verificar também como o docente se posiciona em relação à questão. Se há tal tráfego, se o educador faz uso ou não do potencial comunicativo para estimular a leitura de livros.

Com base no que foi exposto até aqui, o problema para o qual se dirigiram os esforços empregados na elaboração deste trabalho cabe no seguinte enunciado: os meios de comunicação, sobretudo os audiovisuais, como a televisão, o rádio, a internet, o cinema e o videogame, podem contribuir para aproximar os jovens dos livros de literatura?

De maneira complementar, outros dois problemas integram o trabalho por se ligarem diretamente a ele:

a) Na sala de leitura, os alunos são estimulados a vivenciarem uma experiência com os livros a partir dos meios de comunicação? Dito de outra forma, os docentes utilizam de alguma maneira o rádio, a televisão, a Internet e o videogame como ferramentas para aproximar os alunos dos livros e promover leituras transversais?

b) A sala de leitura é um ambiente onde "circula o discurso audiovisual"? Durante as aulas, tanto alunos como professores fazem referências a experiências vivenciadas com os meios de comunicação?

Convém ressaltar que o interesse desta pesquisa não é verificar se o rádio ou a televisão, por exemplo, são capazes de formar leitores. Não pretendemos estudar o desenvolvimento desta prática por influência da eventual mediação do videogame, do cinema ou da internet, entre outros. 
Nosso propósito é observar a possível contribuição dos meios de comunicação para despertar o interesse e motivar os jovens a se aproximarem dos livros por meio destas leituras híbridas, valendo-se de suportes e de linguagens os mais variados, com o robustecimento do espírito crítico e a partir da providencial e necessária mediação dos professores. 


\section{JUSTIFICATIVA}

Em suma, tanto naquelas leituras se enfrascou, que passava as noites de claro em claro e os dias de escuro em escuro, $e$ assim, do pouco dormir e do muito ler, se lhe secou o cérebro, de maneira que chegou a perder o juízo.

(Dom Quixote, Miguel de Cervantes)

Os meios de comunicação, especialmente os eletrônicos, tiveram papel determinante na transformação do processo de leitura e nas formas de aprendizagem. Por um lado, a construção de um modo de interação e percepção imagético, soma de som, cor, imagem, cortes rápidos e tempos mínimos. Por outro lado, os próprios meios de comunicação, em sua capacidade de adaptar os diferentes conteúdos à sua linguagem, criando novas formas de transmissão/absorção de conhecimento. Dos programas educativos ao noticiário, passando pelas novas formas de produção e armazenamento de dados, com a criação de verdadeiras bibliotecas virtuais.

Pensamos que, a TV, a internet, o rádio, o aparelho celular e o videogame podem contribuir com o processo de educação. Alguns destes aparatos cobrem praticamente todo o país e são manipulados com bastante destreza por jovens e adultos.

Dispomos atualmente de uma rara situação de convergência. Apesar das precárias condições de infraestrutura e das dificuldades de lidar com questões básicas, como saneamento e mortalidade infantil, o Brasil conta com uma capacidade instalada de comunicação comparável a de países ricos. Existe um número crescente de pessoas conectadas à internet, contabiliza-se uma média de um celular por habitante, quase 100\% dos domicílios dispõem de aparelhos de televisão e rádio, há uma enxurrada de games piratas comercializados nos grandes centros e - o que parece mais importante - uma habilidade aparentemente incomum no trato com as novas tecnologias.

A pirâmide demográfica do país aponta uma população com média de idade bastante baixa, dotada de grande facilidade para se inserir em mundos virtuais. Filhos da era da informação, lidam com controle remoto, teclado e monitor melhor do que 
com o livro, têm mais intimidade com os aparatos tecnológicos e se reconhecem em tais plataformas.

Esta proximidade observada entre os media e a sociedade, bem como os potenciais benefícios que a relação poderia representar para o desenvolvimento intelectual, profissional e humano, despertaram o interesse de grupos de pesquisadores, que passaram a desenvolver trabalhos a partir do encontro entre as áreas da comunicação e da educação. Com o objetivo de buscar caminhos alternativos para suprir deficiências seculares, acabam por confrontar teorias já estabelecidas, teorias estas que criticam os chamados meios de comunicação de massa.

Neste contexto, o presente trabalho se justifica como tentativa de contribuir com a educomunicação, seja reafirmando certos conceitos e perspectivas, seja, na medida do possível, sugerindo caminhos para pesquisas futuras. Busca-se colaborar com o objetivo comum de fortalecer e consolidar uma área ainda emergente, a partir do estudo da possível relação entre a formação das práticas de leitura e os meios de comunicação.

A leitura de livros é considerada importante para o desenvolvimento de certas habilidades cognitivas. Ela é exaltada como meio para o aprimoramento da escrita e de organização diferenciada do pensamento. Quem lê com mais frequência tem a possibilidade de entrar em contato com um nível de informação e conhecimento mais complexo, de maior profundidade e pode adquirir um repertório de dados amplo.

Silva acredita que o leitor tem um diferencial em relação ao não-leitor, uma vez que "ler se constitui num instrumento de luta contra a dominação.” (2001:49). Para a autora, o primeiro seria mais intelectualizado, mais bem "preparado para o mundo” que o segundo.

Se por um lado há o entendimento mais pragmático e instrumentalizado dos benefícios da leitura de livros, isto é, de que eles representam um caminho para o aprendizado, um meio para a absorção de conhecimento, por outro, cabe destacar sua capacidade de estimular a imaginação. A possibilidade de transposição dos limites do pensamento, o potencial de nos colocar no lugar do outro, como salienta Jouve, de 
viver esta vida que não é nossa, sem necessariamente presenciar e experimentar a realidade descrita.

Ao tratar o tema, pensamos na prática leitora como meio de auxiliar na busca e conquista da autonomia do indivíduo. A palavra escrita como caminho para a expansão do ser consciente, do amadurecimento pessoal, do caráter humanista. Identificar soluções que apontam a televisão, por exemplo, como forma de resgatar o livro, a ficção, a fábula, o romance, como componente do comportamento social, representaria, da mesma forma, um caminho para a redução da desigualdade e de aprimoramento do pensamento crítico no sentido benjaminiano, que o define como meio para "libertar o futuro de sua forma presente e desfigurada". (BOLLE, 1997:11)

Nesta perspectiva, julgamos oportuno, em primeiro lugar, verificar se não seria precipitada a simples condenação destes aparatos, acusados de serem manipuladores, alienantes, meros produtos do entretenimento, que afastam as pessoas dos livros. Em segundo lugar, detectar eventuais mecanismos de apropriação destes recursos justamente para fazer o oposto: contribuir para a formação de leitores. Isto porque, à medida que um cenário igualitário se configura, elevam-se as possibilidades de se conquistar a almejada condição de menor desigualdade e de universalização da educação.

Reiteramos que não pertence ao escopo deste trabalho de pesquisa discutir ou analisar a qualidade e o conteúdo daquilo que é lido, se e como ocorre o desenvolvimento da prática leitora. Entretanto, compartilhamos da concepção de Rezende, que chama a atenção para a necessidade de haver um estímulo à interação mais ampla dos estudantes com os livros, que não se limite a um modelo de ficção midiática considerado mais digerível, mas admita o universo de outras possibilidades. "É preciso que se leia literatura na escola, em todas as suas formas, para que se criem leitores autônomos e críticos de verdade.” (2009:302) 


\section{SOBRE EDUCAÇÃO}

A educação é um dos elementos centrais do presente trabalho. Como afirmamos no capítulo destinado ao problema e aos objetivos da pesquisa, nossos anseios estão diretamente relacionados à possível interação existente entre ela, os meios de comunicação e a prática leitora.

Tendo em vista a importância do tema, acreditamos que seria conveniente fazer algumas considerações antes de nos aprofundarmos nas reflexões acerca do papel dos media nas sociedades contemporâneas, nas discussões sobre a importância dos livros na atualidade e na apresentação dos resultados do trabalho de campo.

Um primeiro ponto a ser considerado diz respeito aos debates promovidos em torno dos desafios da educação, que deveria ser revista em tempos marcados pela intensa influência dos meios de comunicação nas relações humanas e sinalizaria para a necessidade de um novo modelo educacional. Amplamente discutido por estudiosos, pedagogos e, de certa forma, pela própria sociedade, este novo modelo se basearia em alternativas mais democráticas de ensino, onde prevaleceria a participação maior dos alunos, o estímulo e ampliação do diálogo e a proximidade entre educadores e estudantes. Também seria valorizada a utilização de novos recursos, como os aparatos tecnológicos, e de novas linguagens, sobretudo aquelas que representam as vivências e experiências individuais e coletivas dos aprendizes.

O ponto de partida desta discussão guarda relação com um tema caro a Adorno (2006) e seu entendimento acerca do ensino formal. Constituído na antítese do que considera propostas cerceadoras de formação intelectual, que minam a capacidade de pensar dos estudantes e que os direcionam a um meio de conhecimento instrumentalizado, voltado estritamente à capacitação profissional e às expectativas do mercado, o pensamento do filósofo alemão se baseia na premissa de que a educação é, em primeiro lugar, um ato de emancipação. Neste sentido, ela deveria estar voltada ao desenvolvimento da autonomia dos indivíduos. As aptidões intelectuais estimuladas não como forma de atingir a disciplina, a retidão e a 
obediência, mas com o objetivo de exercitar a criatividade, de lapidação do espírito crítico e de exaltação das individualidades.

As propostas pedagógicas que vigoram desde a Revolução Francesa e que pouco teriam se aperfeiçoado desde então, no entendimento de Adorno, em nada se aproximam deste ideal libertário. Muito pelo contrário, parecem valorizar justamente características que tendem a limitá-lo, como a ordem e a disciplina.

A análise da obra Educação, autoridade, responsabilidade - reflexões para uma ética pedagógica, escrita por Ernest Linchtenseteinm, municia esta posição refratária em relação à escola convencional e seu caráter senil. Defensor de um modelo calcado na autoridade e na ordem, ele entendia como ameaça ou manifestação da decadência toda e qualquer expressão ou comportamento que estivesse à margem do sentido de obediência. E dentre as expressões que melhor se ajustariam à imagem ideal das instituições de ensino estariam o respeito, a ordem $e$ o compromisso.

A crítica de Adorno ao pensamento de Linchtenseteinm se direciona justamente ao que o último considera o aspecto primordial. A disciplina, as regras e os ditames impingidos pela instituição representam para o primeiro uma forma de aprisionamento, uma vez que a finalidade da escola deveria ser exatamente oposta.

"Mas, no lugar de emancipação, encontramos um conceito guarnecido nos termos de uma ontologia existencial de autoridade, de compromisso, ou outras abominações que sabotam o conceito de emancipação atuando assim não só de modo implícito, mas explicitamente contra os pressupostos de uma democracia." (ADORNO, 2006:172)

Outro ponto que merece destaque refere-se ao que poderíamos chamar de uma concepção clássica da educação, moldada a partir do ideal de formação de Aristóteles, e os abalos que ela teria sofrido especialmente no decorrer do último século. 
O pensador grego considerava que o homem, ao nascer, é uma espécie de página em branco que, ao longo da vida, vai sendo preenchida. Portanto, em nossa trajetória pessoal, temos a oportunidade de aprimorar, exercitar e desenvolver nossas habilidades a partir do acúmulo de conhecimento, que dá acesso a novos e mais complexos degraus da escala evolutiva.

A princípio, a educação formal, a que temos acesso por meio da escola, foi fundada com base neste parâmetro. A divisão em séries, a criação de ciclos, o sistema de avaliação e a sistematização e organização dos conteúdos dão conta desta relação. Cabe nesta reflexão a menção à amplitude do termo disciplina, que, com o passar do tempo, abarcou a organização dos assuntos a serem ensinados, suas formas demarcatórias e os limites estabelecidos entre eles. Embora originalmente estivesse vinculado, conforme as palavras de Chervel, à ideia de "vigilância dos estabelecimentos, à repressão das condutas prejudiciais à sua boa ordem e àquela parte da educação dos alunos que contribui para isso” (1990:178) o termo passou a ser admitido também para estabelecer a divisão entre matérias: matemática, língua portuguesa, história, geografia...

Não totalmente desvinculado de sua primeira acepção, o termo disciplina foi aprimorado a partir de um modelo pedagógico que se desenvolveu depois da segunda metade do século XIX, e que se caracteriza pela "estreita ligação com a renovação das finalidades do ensino secundário e do ensino primário". Neste sentido, haverá uma aproximação com o que se convencionou chamar de "ginástica intelectual.” (1990:179)

Por um lado, a possibilidade de especialização dos docentes e o aproveitamento das aulas de acordo com assuntos específicos. Por outro, o aumento do grau de complexidade à medida que os estudantes adquirem novas habilidades e as desenvolvem.

Ainda neste contexto, a metáfora de que o homem é uma pedra bruta a ser esculpida é apropriada para se referir às estratégias definidas nos programas curriculares e aplicadas em sala de aula. Os estudantes entram em contato com um universo de teorias, conceitos, normas, símbolos, índices, fórmulas e teoremas que se acumularam ao longo do tempo e que proporcionam a passagem entre o estágio 
abstrato, sem delimitações claras, para o concreto e bem definido. Nas palavras de Rocha, "a formação é, portanto, passagem do mais indeterminado ao mais determinado.” (2006:269)

No entanto, novas demandas sociais foram surgindo e, profundamente influenciadas pelos meios de comunicação, tiveram como consequência mudanças em relação às possibilidades de aquisição do conhecimento. Com isso, a chamada educação informal, proporcionada por interações com agentes externos à educação formal e do qual fazem parte os media, ganhou espaço na sociedade.

Por outro lado, tendo em vista as características dos produtos midiáticos, que não foram criados para educar e sim para entreter, seus objetivos levam em consideração a veiculação da maior quantidade de informação possível, ou seja, salvo algumas exceções, não há preocupações em relação à qualidade - há uma preferência pela fragmentação e por produtos descartáveis.

Verifica-se, em função deste cenário, uma tensão entre a educação formal e a informal. A escola, que requer um tempo diferente daquele vivenciado fora dela e valoriza a construção de um conhecimento pautado em programas, estruturas curriculares e, portanto, no ideal de formação, entra em conflito com estes outros meios de aquisição do conhecimento, que são mais vinculados à mobilidade e à transformação.

Neste contexto, o ponto de vista que prevaleceu por mais de dois mil anos, que dá conta de verdades universais e do homem como uma pedra bruta a ser lapidada, dá espaço ao argumento oposto, que se distancia da perspectiva aristotélica e se aproxima de Nietzsche, que, num sentido radical da percepção acerca da aquisição do conhecimento, valoriza mais o processo de transformação. Ao homem cabe anarquizar o tradicional, reinventá-lo, opor-se a ele. Neste caso, é a metáfora da água a ser usada. Líquida, incapaz de ser contida, de se fixar, trilha diferentes caminhos, sem direção certa, além de poder assumir momentaneamente outros estados (líquido e gasoso).

Rocha (2006) desenvolve esta reflexão, que contrapõe as ideias de Aristóteles às de Nietzsche sob a ótica da educação, no artigo Tornar-se quem se é: 
educação como formação, educação como transformação. Ao mencionar as trajetórias do conhecimento, ela pondera a possibilidade de se desenvolver projetos pedagógicos em uma época em que predominam as formas intangíveis, voláteis e incertas de se efetivar a aprendizagem.

A concepção nietzschiana revelada pela autora se alinha ao entendimento de que o sujeito não é forjado a partir de um determinado ponto inicial e disforme para um fim específico. O indivíduo se constitui a cada nova experiência, que tem como resultado a apropriação do saber e, partindo deste princípio, o processo distancia-se dos conceitos de consolidação, acúmulo ou estatismo do conhecimento. “ $A$ possibilidade de constantemente se reinterpretar, se reinventar, diferir de si mesmo" (2006:271) é quase uma negação do que foi, do que era, uma ação de desligamento da memória, a "permanente disponibilidade de romper com aquilo mesmo que se reconhece como 'eu'”. (2006:272)

A volatilidade dos nossos dias é abordada também por Bauman (2009), mas a partir de uma concepção especialmente voltada para a sociedade de consumo. O sociólogo polonês, que ficou conhecido por cunhar expressões como sociedade líquida, modernidade líquida e amor líquido, faz um diagnóstico pouco otimista das condições da cultura atual. A ausência de um mundo palpável, ou melhor, a substituição de uma realidade tangível, sólida, possível de se apreender, por outra que se caracteriza pela inconsistência, pela imprevisibilidade, onde o que vale é o descartável, o substituível, o imediato e o efêmero; em um tempo em que "caminhar é melhor que ficar sentado, correr é melhor que caminhar e surfar é melhor que correr" (2009:661), ele afirma que existe uma priorização pela mobilidade em detrimento do estático. Comprometimento é quase sinônimo de inflexibilidade, um fardo que pode significar estagnação e desatualização. Em síntese, viver no século XXI é estar atento para o novo de todos os dias, que nasce quase velho e, não raro, morre antes de amadurecer.

“No mundo líquido moderno, de fato, a solidez das coisas, tanto quanto a solidez das relações humanas, vem sendo interpretada como uma ameaça: qualquer juramento de fidelidade, compromissos a longo prazo, prenunciam um futuro sobrecarregado de vínculos 
que limitam a liberdade de movimento e reduzem a capacidade de agarrar no vôo as novas e ainda desconhecidas oportunidades.” (2009:662)

Da concretude para a liquidez, vivemos dias nos quais o que antes era palpável hoje escorre pelas mãos. Parece haver um desafio aí, no sentido de encontrar alternativas que levem em consideração essa ideia de transitoriedade. Também se apropriando da metáfora da água, Lévy associa o ciberespaço a um rio, que permite a universalização da informação, mas que, por conta da falta de controle, sofre com problemas permanentes de enchente. "Não contente de correr sempre, o rio de Heráclito agora transbordou.” (2008:151) 


\section{LEITURA E NOVAS LEITURAS}

Este capítulo tem o objetivo de apresentar conceitos a respeito da leitura e, de maneira mais específica, da leitura de livros, tendo em vista o papel de centralidade que ela ocupa na presente pesquisa. Buscaremos resgatar elementoschave neste processo que envolve, entre outras coisas, a obra e o leitor, a relação de tensão que se dá entre eles, a partir daquela que nos parece a questão elementar neste processo: o que é ler?

Sempre a partir de uma perspectiva que toma o livro como referência, podemos inicialmente nos apoiar em ideias como as de Solé, que considera este processo interativo e afirma que, para realizá-lo de maneira efetiva, o leitor precisa “dominar habilidades de decodificação” (2008:23). Ele depende de conhecimentos sobre a língua, entender o significado das palavras e as regras gramaticais, entre outros.

A autora afirma que não se trata de um contato aleatório. A leitura é guiada por algum motivo, por uma busca por satisfação, seja ela de qualquer espécie. Há, portanto, uma expectativa envolvida nesta interação, ou seja, o leitor tem papel ativo ao processar e refletir sobre o texto, que indica a possibilidade de diferentes interpretações, independentemente da intenção original do autor.

Com base neste ponto de vista, o processo de leitura pode ser entendido como a combinação daquilo que se espera dela, naturalmente influenciado pelo conhecimento prévio e pelas experiências individuais, com o nível da habilidade escrita. “Assim, o leitor utiliza simultaneamente seu conhecimento do mundo e seu conhecimento do texto para construir uma interpretação sobre aquele.” (2008:24)

Outros autores, como Smith (1989), desenvolveram trabalhos voltados aos aspectos cognoscitivos envolvidos no ato de leitura. Ele é resultado, ao mesmo tempo, de uma informação visual, que é dada pela obra, na palavra impressa e organizada sob determinados critérios e codificações, e de uma informação não visual. Esta última é do próprio leitor, que resgata seu conhecimento prévio (cultural e linguístico) tanto em relação ao mundo que o cerca quanto no que diz respeito ao assunto daquele texto com o qual estabelece contato. 
Ainda que por caminho distinto, Smith se aproxima de Solé ao sinalizar que a leitura é, em primeiro lugar, constituição de sentido. O leitor ativo se posiciona e constrói significado com base nesta relação entre informação visual e não visual, que é independente dos objetivos de quem efetivamente escreveu o texto. Aliás, ela vai além ao considerar que ler é mais do que a simples compreensão do sentido original da obra, uma vez que para que isso aconteça é necessário que exista um alinhamento de expectativas, objetivos e intenções entre autor e leitor.

Jolibert também partilha da ideia e considera que a razão de existir da leitura é justamente essa apropriação feita por quem lê. Não basta uma razoável competência para interpretação dos signos, mas também este movimento de construção, desconstrução e reconstrução. Para a autora, ler "é atribuir diretamente um sentido a algo escrito, (...) é questionar algo escrito como tal a partir de uma expectativa real (necessidade de prazer) numa verdadeira situação de vida.” $(1984: 15)$

Ao trazer tal abordagem para o universo do nosso interesse, ou seja, a escola, Lajolo amplia a reflexão com o entendimento de que o leitor é a razão de ser da leitura. Segundo ela, é importante considerar as formas de proximidade e observar de que maneira há interação social, por intermédio do texto, entre autor e leitor. Dela, muito mais do que tentativas de transmitir técnicas de interpretação e compreensão do texto, dependeria o sucesso das práticas leitoras.

"A leitura só se torna livre quando se respeita, ao menos em momentos iniciais do aprendizado, o prazer ou a aversão de cada leitor em relação a cada livro. (...)

Menos ou mais sofisticados, os exercícios, que sob o nome de interpretação, compreensão ou entendimento do texto costumam suceder-se à leitura são, quase sempre, exercícios que sugerem ao aluno que interpretar, compreender ou entender um texto (atividades que podem muito bem definir o ato de leitura) é repetir o que o texto diz. O que é absolutamente incorreto.” (2001:109) 
A leitura não é vista pela autora como ato de repetição e treinamento, reprodução de palavra, nem uma postura mecânica. Ela é um processo criativo, libertário, que valoriza a participação do estudante e que permite o desenvolvimento do espírito crítico.

Encontramos também em Bourdieu (2009) considerações que podem contribuir com as ideias tratadas até aqui, que admitem a leitura como uma prática aberta e dinâmica na qual o leitor deve ser reconhecido como condutor e, de certa maneira, co-autor da obra. O pensador francês critica o chamado modelo estrutural de leitura, que considera o texto constituído de uma verdade interna, uma forma definitiva, que sugere a existência de uma maneira correta de interpretá-lo, aceitá-lo e compreendê-lo.

Para o autor, embora a concepção seja relativamente recente, somos fortemente influenciados por ela. Não raro e, muitas vezes, sem nos darmos conta, aceitamos o texto como se ele fosse único e não houvesse nada além dele, outros estímulos, experiências, culturas. Seríamos tentados a tomar como certa esta leitura definitiva, quando na verdade deveríamos ser mais flexíveis, reconhecendo as múltiplas possibilidades de atribuição de significado.

"Pensamos que ler um texto é compreendê-lo, isto é, descobrir-lhe a chave. Quando de fato nem todos os textos são feitos para serem lidos nesse sentido. (...) Há toda espécie de texto que pode passar diretamente ao estado da prática, sem que haja necessariamente mediação de uma decifração no sentido em que a entendemos." (BOURDIEU, 2009:233)

Diante do exposto até aqui, concluímos que a leitura de livros depende de uma capacidade cognitiva e de habilidade de decodificação, isto é, um conhecimento da linguagem (e suas regras) utilizada para a elaboração do texto. O maior ou menor domínio sobre tais técnicas vai produzir efeitos na compreensão e interpretação, mas não será exclusivo na prática leitora. Isto porque tal processo é influenciado também (e principalmente) pelas expectativas do leitor, que tem 
objetivos individuais, de maneira que a interação entre o sujeito e o livro é influenciada por outros e diferentes estímulos, a depender do contexto e da realidade social em que ela ocorre.

Por reconhecermos, por um lado, as variadas formas de leitura e, por outro, a influência de fatores culturais neste processo, abordaremos também algumas reflexões sobre as leituras da atualidade. Levando em consideração um dos elementos-chave do nosso estudo, os meios de comunicação, trataremos a questão sob esta perspectiva, com apontamentos a respeito das possíveis mudanças ocorridas por influência dos media.

\subsection{Leituras midiáticas}

É fato que os meios de comunicação pertencem ao cotidiano dos alunos. Eles passam, por exemplo, boa parte do dia expostos à televisão, à internet, ao rádio e ao videogame. Frequentemente o resultado das vivências com estes aparatos estão presentes no comportamento, na expressão nova, na música, na forma de se vestir, na opinião sobre determinado tema.

E não só dos alunos. Este é o universo dos professores também. Ainda que moldados em gerações diferentes, tanto uns quanto outros pertencem ao ecossistema comunicativo. A expressão cunhada por Martín-Barbero remete a novos olhares sobre as formas de educar - e aqui, mais do que nunca, no plural -, abre espaço para se discutir a valorização de outras competências e habilidades, uma compreensão mais abrangente em relação ao significado do conceito de alfabetização.

"A escola, parte do ecossistema comunicativo e dos novos formadores do espaço público, dos quais os media formam o conjunto mais visível, está, ao mesmo tempo, determinada a dignificar a sua linguagem de base, construída, no fundamental, pela palavra, e desafiada a trabalhar com outras linguagens, lendoas, entendendo-as, incorporando-as, infletindo e refletindo sobre 
elas: vale dizer, considerando as múltiplas possibilidades de se produzir os sentidos e, com isto, ampliando o próprio conceito de alfabetização.”6 (CITELLI, 2006:165)

Pesquisadores como Canclini (2008) sugerem que é necessário relativizar considerações sobre a redução do hábito de leitura. Valendo-se de uma série de estudos realizados principalmente na América Latina, como os desenvolvidos pela Associação Mundial de Periódicos, pelo Sistema Nacional de Consumos Culturais da Argentina, pela Colômbia, além da Pesquisa Nacional da Juventude feita no México, o autor aponta uma série de dados aparentemente positivos: (1) aumento do número de leitores paralelo à distribuição de jornais gratuitos; (2) crescimento de 488 milhões para 1,4 bilhões de leitores de periódicos ao longo de cinco anos em todo o mundo; (3) tendência ascendente significativa do consumo de revistas, histórias em quadrinhos, passatempos, além de material veiculado na internet; (4) uso crescente, sobretudo entre os jovens, de computador, aparelho celular, agenda eletrônica, MP3 e videogame, que permitem formas de leitura que não necessariamente substituem, mas podem complementar as tradicionais.

Como salienta o pesquisador, com as novas configurações e comportamentos sociais, "lê-se de outras maneiras, por exemplo, escrevendo $e$ modificando." (CANCLINI, 2008:59) Best Sellers, não raro adaptados “para” ou “de” outras linguagens, como o cinema e os games. Os universitários formam livros montados a partir de fotocópia de capítulos de diferentes obras. Fragmentos. Textos curtos, twitter, mensagens de pagers e aparelhos celulares. Assim, como falar em prevalência de imagens quando “as telas do nosso século” foram feitas também para a palavra escrita?

Outros autores, como Eco e Carrière (2010), manifestam-se contrariamente aos que acreditam que os meios de comunicação reduzem as práticas leitoras. Mais do que isso, contestam as previsões mais radicais, que dão conta do fim do livro,

\footnotetext{
${ }^{6}$ Grifo do autor.
} 
sob o argumento de que os meios eletrônicos, como o computador e o livro, têm características e servem a funções e necessidades distintas.

O semiólogo italiano enfatiza, por exemplo, que em cinco séculos o desenho do objeto livro, a estrutura da organização das palavras, os formatos e padronizações, como as linhas, numeração e ordenação de páginas, etc., praticamente não mudaram. Para ele, ainda que seja possível modernizar seus componentes, tornando-o mais acessível, portátil, com maior capacidade de armazenamento, o livro perderá pouco das suas características originais.

"O livro é como a colher, o martelo, a roda ou a tesoura. Uma vez inventados, não podem ser aprimorados. Você não pode fazer uma colher melhor que uma colher. (...) O livro venceu seus desafios $e$ não vemos como, para o mesmo uso, poderíamos fazer algo melhor que o próprio livro. Talvez ele evolua em seus componentes, talvez as páginas não sejam mais de papel. Mas ele permanecerá o que é.” (ECO e CARRIÈRE, 2010:17)

Podemos acrescentar, como destaca Reimão, que, no decorrer dos séculos, o livro assumiu diferentes formatos e características físicas, assim como sofreu variações "nas práticas sociais de aproximação e de seu apossamento, produzindo usos e significações amplamente diferenciados.” (2004:97). Não seria de todo equivocado considerar a partir da constatação, que as novas formas e linguagens introduzidas pelos meios de comunicação poderão estimular novas apropriações, a partir de necessidades e demandas sociais.

Belo (2008) lembra que as previsões desfavoráveis ao livro são feitas há bastante tempo. No século XIX, com o barateamento e popularização do jornal, especialistas estipulavam apenas algumas décadas de vida para os livros, que, no prognóstico deles, em menos de cinquenta anos não seriam mais impressos, pois aos poucos os leitores perderiam o interesse nos últimos em favor do primeiro. Assim como os meios de comunicação eletrônicos hoje, os periódicos noticiosos e 
os folhetins eram vistos como prejudiciais à educação, à intelectualização e ao desenvolvimento do espírito crítico.

Ao traçar um paralelo entre as projeções antigas e atuais, o autor recomenda cautela. Reitera que, contrariando os pessimistas de ontem, o suporte (livro) se mantém até os dias hoje, e acredita que ainda pode contrariar os céticos da contemporaneidade, que responsabilizam, por exemplo, o computador e suas possibilidades pela extinção da palavra impressa.

Em sua opinião, os recursos oferecidos pelas ferramentas informatizadas tendem a valorizar e estimular as práticas leitoras e, por consequência, tais recursos garantirão que os livros sejam preservados. Belo aponta, entre os benefícios que os favoreceriam, as obras disponíveis gratuitamente e de fácil acesso na internet, o que permite o contato de um número muito maior de pessoas com um universo de textos, artigos científicos e obras literárias antes praticamente inacessíveis.

O pensador francês acredita que a postura antagônica é comum diante do desconhecido. Neste sentido, "se o futuro do livro é incerto, parece cada vez mais claro que anunciar sua morte é mais um sintoma de incapacidade para compreender bem as mudanças em curso do que um diagnóstico rigoroso do que está acontecendo.” (BELO, 2008:22)

A mesma opinião tem Murray (2003), para quem o computador, na verdade, "não é inimigo do livro". Originado da cultura impressa, se tomada como referência a prensa de Gutenberg como marco inicial, ele seria “o resultado de cinco séculos de investigação e invenções organizadas e coletivas que o texto impresso tornou possível.” (2003:23)

Lévy (2008) também tece considerações sobre a tecnologia e a multiplicidade de recursos especialmente oferecidos pelas plataformas virtuais. Ele destaca que a cibercultura se caracteriza pela liberdade, a interatividade e pela potencialização de um aspecto fortemente ligado à pratica leitora: a possibilidade de construção e de realização de uma leitura pessoal. Nela, "o texto dobra-se, redobra-se, divide-se e volta a colar-se pelas pontas e fragmentos: transmuta-se 
em hipertexto, e os hipertextos conectam-se para formar o plano hipertextual indefinidamente aberto e móvel da web.” (2008:149)

Canclini pondera ainda quanto às diferentes concepções de leitura, sobretudo quando ela parte de uma visão que poderíamos chamar tradicional, isto é, de alguém mais familiarizado com a cultura letrada, de um leitor que não se constituiu influenciado pelas ferramentas de comunicação contemporâneas, particularmente no ambiente virtual da internet, onde leitor e autor se confundem. “Quem lê sem separar aquilo que, nele, também é espectador e internauta, lê -e escreve - de uma maneira enviesada, incorreta para os adeptos da cidade letrada." (2008:59)

Entretanto, vale considerar a possibilidade de ser exatamente este o ponto de partida - ou de retomada. Mais do que pensar em como utilizar os meios de comunicação para desenvolver habilidades “desejáveis”, que se voltem estritamente à educação formal, seria o caso, como já foi dito, de refletir a respeito do que pode haver de complementaridade nesta relação. 


\section{CORRENTES CRÍTICAS: MEIOS DE COMUNICAÇÃO E A LEITURA DE LIVROS}

A consolidação dos meios de comunicação, a partir da impressão massiva de folhetins, depois com o cinema, seguido do rádio e assim por diante, é considerada por alguns estudos como responsável pelas transformações ocorridas no hábito de leitura. Trabalhos desenvolvidos desde meados do século XIX, quando tais media começaram a se popularizar, dão conta de uma visão temerosa em relação aos seus impactos no comportamento social.

Ora vistos como alienantes, responsáveis por desviar o leitor do que poderia ser considerada boa literatura, em contrapartida à má literatura, que seria promovida pela indústria do entretenimento, tida como culpada por privilegiar a otimização dos meios de produção, o lucro e os modelos pré-formatados e fragmentados; ora acusados de direcionar o hábito de leitura para outros meios, o que se traduziria, por exemplo, na substituição de algumas dezenas de páginas de livros pelo aparelho televisor, tal movimento teria provocado mudanças vistas como prejudiciais por algumas correntes de pensadores.

O capítulo em curso será dedicado à exposição destas ideias que confrontam os meios de comunicação. Embora a proposta do presente trabalho se alinhe a uma perspectiva diferente, que parte do princípio de que os meios de comunicação podem ser utilizados como aliados no processo de educação, entendemos que existe um encadeamento histórico, com sua indiscutível relevância e influência. Para além de representar apenas um ponto de vista, o posicionamento refratário em relação aos media revela o processo evolutivo das diferentes teorias, considerando-se a época, assim como as condições sociais e econômicas em que elas vieram à tona.

O objetivo, portanto, é apresentar e destacar aspectos pertinentes destas teorias, isto é, dar ênfase a ponderações que se mantêm atuais e que, por esta razão, não podem ser simplesmente ignoradas. Além disso, traçar um paralelo entre tais estudos e as ideias que permeiam o presente projeto de pesquisa, tendo em vista a intenção de melhor delimitar os caminhos que pretendemos trilhar. 


\title{
7.1 Primeiras críticas
}

Muito embora tal debate sobre os meios de comunicação de massa e seus potenciais malefícios tenha ganhado força a partir da Escola de Frankfurt - e por razões óbvias, afinal, eles começaram, de fato, a se robustecer principalmente após a primeira década do século XX -, outros pensadores já haviam dedicado atenção especial ao assunto. Sobretudo no que se refere aos hábitos da burguesia em ascensão, bem como ao comportamento da classe operária que se formou após a revolução industrial.

Em Ciência e Jornalismo - da Herança Positivista ao Diálogo dos Afetos, Cremilda Medina discorre acerca da insatisfação do filósofo Auguste Comte em relação ao contato que principalmente as classes sociais economicamente menos favorecidas mantinham com certos tipos de literatura, considerados menores, como os romances populares. O estrito racionalismo passou a ser visto como meio de superar os descaminhos sedutores aos quais conduzia a Indústria Cultural que, apesar de ainda estar em uma fase embrionária à época, já era considerada uma ameaça.

\begin{abstract}
"Curioso o pensador não estar muito distante do pensamento apocalíptico posterior, já na primeira metade do século $X X$, que condena pela alienação ou manipulação das consciências, os periódicos, as novelas e os dramas. O autor condena o desfrute dessa produção simbólica pelas classes inferiores, 'às quais nenhuma instrução regular preserva no contágio metafísico, só rechaçado por sua razão natural'. A educação positivista seria, então, o antídoto para o tríplice e desviante ensino que emana dos periódicos, ou seja, do jornalismo, das novelas e dos dramas da literatura folhetinesca do século XIX.” (2008:22)
\end{abstract}

Até parte dos próprios escritores mantinha posição crítica a respeito do tema. Alguns censuravam seus pares, companheiros no ofício, como Tolstói (NUNES, 2004:53-54), que não poupava críticas ao conterrâneo Dostoiévski. Em 
sua opinião, o autor de Crime e Castigo era responsável por uma literatura mal feita, de gosto duvidoso, sem a mínima preocupação estética, e, por esta razão, uma péssima influência para os ávidos consumidores de folhetins ${ }^{7}$. Outros se lançavam diretamente contra os próprios leitores. É o caso de Flaubert, que se voltava contra a burguesia, que, em sua opinião, não era capaz de contemplar a obra de arte da maneira devida.

Já nos primeiros anos do século passado, em paralelo ao desenvolvimento e consolidação de alguns meios como o jornal, o cinema e o rádio, que já atingiam um número bastante elevado de pessoas, os trabalhos científicos que tinham como abordagem a comunicação se tornaram cada vez mais numerosos. Nos Estados Unidos, a Escola de Chicago e os estudos sociológicos que envolviam as comunidades estrangeiras; a Mass Communication Research, o esquema linear de comunicação e a influência do behaviorismo; a Teoria da Informação, sua base matemática e a busca pela perfeição na transmissão da mensagem; e a Cibernética, com a introdução do conceito de feedback e a preocupação com o contexto em que dada mensagem circula são referências daquelas que ficaram conhecidas como teorias funcionalistas da comunicação. (MATTELART, 2010)

Paralelamente e de maneira mais direta a partir da década de 30, um grupo de pesquisadores de origem alemã inaugurou a corrente crítica das pesquisas de comunicação com a Escola de Frankfurt. No célebre texto A indústria cultural, Theodor Adorno, que está entre seus fundadores e é considerado um dos principais expoentes entre estes estudiosos, afirma que os meios de comunicação de massa e a Indústria Cultural transformaram cidadãos em consumidores, com prejuízos em diferentes aspectos da vida social. No campo das artes, por exemplo, os males teriam afetado o que o próprio autor classifica como "arte superior" e "arte inferior”.

\footnotetext{
${ }^{7}$ Neste aspecto é interessante verificar como Bakhtin reconhece neste aparente "discurso" de Dostoiévski uma marca que mostra a riqueza dos processos dialógicos. A prosa do autor russo se destaca pela polifonia de vozes que cruzam níveis e modalidades variadas da língua russa, originárias dos mais variados extratos sociais. BAKHTIN, Mikhail. Problemas da Poética de Dostoiévski. São Paulo: Forense Universitária, 5º ed., 2010.
} 
"A arte superior se vê frustrada de sua seriedade pela especulação sobre o efeito; a inferior perde, através de sua domesticação civilizadora, o elemento de natureza resistente e rude, que lhe era inerente enquanto o controle social não era total.” (1971:287-288)

$\mathrm{Na}$ concepção do teórico, com a revolução industrial e a ascensão do capitalismo, os integrantes das classes abastadas teriam encontrado, na cultura de massa, meios para dominar os menos favorecidos, especialmente o operariado. A condição de alienação, segundo este entendimento, se tornou uma das principais características sociais a partir daquele momento. As produções artísticas e as formas de entretenimento criadas pelos novos aparatos seriam utilizadas para manipular, para “domesticar” o grande contingente de miseráveis.

E, se por um lado, as características necessárias para o funcionamento do sistema capitalista, quais sejam a redução de custos, a repetição e produção em larga escala, a “coisificação” e a simplificação dos produtos, conduziram ao processo de alienação das massas, a chamada cultura superior também teria sido deturpada de seu sentido original. O caráter personificado da obra de arte se perdeu com a banalização e com o reducionismo. O erudito, com suas exigências básicas, como a necessidade de acumular conhecimento, do aprimoramento intelectual, teria igualmente sofrido revés sem precedentes.

Ao tratar dos reflexos desta "situação de degradação” na música, Adorno e Horkheimer abordaram as transformações pelas quais teria passado o gosto musical. Para ambos, perderam-se os critérios para a determinação do que é bom e do que é ruim, do reconhecimento do belo, da contemplação da produção genuinamente artística.

“Contudo, assim como não se pode qualificar de dionisíaca a consciência musical contemporânea das massas, da mesma forma pouco têm a ver com o gosto artístico em geral as mais recentes modificações desta consciência musical. O próprio conceito de gosto está ultrapassado. A arte responsável orienta-se por critérios que se 
aproximam muito dos do conhecimento: o lógico e o ilógico, o verdadeiro e o falso. De resto, já não há campo para escolha; nem sequer se coloca mais o problema, e ninguém exige que os cânones da convenção sejam subjetivamente justificados.” (1999:65-66)

No mesmo trecho, eles discorrem com maior profundidade a respeito da inexistência de escolhas; sobre a obrigatoriedade de aceitarmos o que recebemos e ponto final. O método impositivo capitalista passaria despercebido dos consumidores, que seriam alvejados o tempo todo por novos hits, novos sucessos, uma nova moda, sempre efêmeros e fragmentados. E nesta perspectiva, os parâmetros para a atribuição de valor e de reconhecimento da obra estariam diretamente ligados ao seu potencial de se popularizar. Ela seria melhor quanto mais difundida, famosa e mais massificada pudesse ser. "Em vez do valor da própria coisa, o critério de julgamento é o fato de a canção de sucesso ser conhecida de todos; gostar de um disco de sucesso é quase exatamente o mesmo que reconhecê-lo.” (1999:67)

A síntese das ideias até aqui apresentadas, direcionadas para o âmbito da questão da leitura de livros, levar-nos-ia a pelo menos três conclusões. Em primeiro lugar, os meios de comunicação teriam sido responsáveis pelo rebaixamento da qualidade das obras. Para caber em seus formatos mínimos e dar conta da necessidade de contínua renovação, os autores passaram a trabalhar por demanda e a plástica, a estética dos livros - e não apenas no que se refere ao conteúdo, mas também fisicamente falando -deu lugar ao fator tempo, ou seja, melhor será aquele que for entregue em tempo, para ser impresso e distribuído a fim de saciar o desejo dos consumidores.

Em segundo lugar, e como consequência da primeira conclusão, os leitores seriam os principais prejudicados. Ao consumirem uma literatura menor, eles teriam espaço reduzido para o desenvolvimento do espírito crítico, para a formação da consciência. O vocabulário mínimo, as histórias repetidas, a ausência de temas complexos, a fragmentação, a efemeridade e a cultura do descartável acabariam por incentivar a alienação. 
E em terceiro lugar, a concorrência de outros media, como o cinema, o rádio e a televisão, teria tornado a leitura da palavra impressa e mais especificamente do livro uma atividade cada vez menos atraente. Esta seria, inclusive, uma das explicações para a redução, década a década, do número de livros lidos por indivíduos.

Além disso, expandindo um pouco tal inferência, esta concorrência dos meios eletrônicos teria agido diretamente no sistema de ensino, que, como se sabe, foi constituído a partir da cultura letrada. Neste sentido, parece impossível à escola tentar tratar qualquer tipo de disputa. Diante da tela iluminada, o livro didático, a lousa e o giz seriam convites ao tédio, ao desestímulo e à impaciência para as atuais gerações.

Manifestações típicas deste entendimento podem ser encontradas no próprio arquivo da Secretaria Municipal de Educação da cidade de São Paulo. Um livro elaborado pelo próprio órgão, publicado em 1978, intitulado Programa Escola Biblioteca, oferece uma boa dimensão de como os meios de comunicação de massa eram vistos pelos gestores da área educacional. O documento fazia alusão às salas de leitura, cujo início da implantação se deu cerca de dez anos antes e basicamente consistia na formação de acervos próprios nas unidades escolares, a oferta de um bibliotecário e a capacitação de professores com o intuito de estimular o hábito de leitura nos alunos.

Logo na introdução da obra, o então secretário Municipal de Educação, Hilário Torloni, tratou das dificuldades verificadas à época quanto à formação de um público leitor. Para além do problema crônico do analfabetismo, ele mencionava os prejuízos causados pela rápida disseminação do cinema, do rádio e da televisão, que segundo ele seriam formas de entretenimento alienantes, desviantes, corruptoras e provocadoras do “atrofiamento da linguagem”. Segundo o titular da pasta, era difícil competir com esse novo tipo de entretenimento, que em fins daqueles idos de 70 representava um mal que atingia quase a totalidade da população, uma vez que naquele período as crianças já passavam mais tempo em contato com os media do que na escola. 
"Será uma consequência da multiplicação do número de rádioouvintes?

Especialistas em 'mídia' afirmam que o Rádio, hoje, alcança 90\% da população brasileira, sendo, por isso, o veículo de maior penetração nacional.

Será o efeito do império da televisão?

Segundo os mesmos especialistas, $90 \%$ da população urbana brasileira veem televisão.

É óbvio que quem ouve rádio ou vê televisão deixa, quase que insensivelmente, o hábito de ler.

E quanto às crianças e os jovens?

Rádio, televisão, cinema e histórias em quadrinhos serão os “vilões” responsáveis pela acentuada redução do número dos que leem?

A criança e o jovem, entre nós, permanecem na escola, no máximo, durante quatro horas, enquanto assistem TV, ouvem Rádio ou frequentam cinema numa proporção que oscila de oito até dez horas diárias!

Os veículos de comunicação, pela sua natureza, induzem o ouvinte, o telespectador ou o cine-espectador a 'esquecer' o grupo familiar, os amigos ou parentes, quando reunidos, visto que as pessoas tendem a irritar-se com qualquer tipo de interrupção que lhes perturbe durante a recepção do que estão ouvindo ou vendo.

É o fenômeno do isolamento em grupo, quer a pessoa esteja dentro de sua casa, em um clube, num estádio ou numa sala de cinema, cuja consequência visível é o atrofiamento da linguagem, algo paradoxal nesta era da multiplicidade dos meios de comunicação.

O fato é que os sumários informativos transmitidos pelos meios eletrônicos parecem satisfazer à maioria, reduzindo ainda mais a vontade de ler.

Se os adultos não querem ler e se os jovens seguem a mesma tendência de desamor à leitura, quais as providências para alterar esta situação? 
Urge, evidentemente, a adoção de medidas capazes, ainda que lentamente, de modificar esse entristecedor panorama.” (1978:3-4)

Torloni se posicionava radicalmente contra os meios de comunicação eletrônicos. Além de considerá-los responsáveis diretos pela redução “da vontade de ler", via-os como estimulantes de um comportamento social individualista, caracterizado pelo isolamento das pessoas, que, por permanecerem muitas horas em frente ao aparelho de rádio e de televisão, acabavam por acumular um conhecimento superficial. Aliás, admitia apenas uma saída para este cenário catastrófico: que fossem tomadas atitudes emergenciais. Até onde podemos supor, tal transformação se daria por intermédio da criação de mecanismos que estimulassem as pessoas a lerem mais ao mesmo tempo em que as levariam a reduzir o contato com os media.

Não parece correto simplesmente aceitar como verdadeiras tais colocações. Passados mais de 30 anos desde a publicação das constatações do então secretário Municipal de Educação, a comunicação se tornou ainda mais abrangente e diversificada, com penetração maior no cotidiano social. Três décadas depois, não apenas temos aparelhos televisores em quase a totalidade dos domicílios brasileiros, mas também contamos com telefones que cabem na palma da mão, dispensam cabos, permitem a transmissão de arquivos e mensagens de texto e oferecem outros recursos como fotos e filmagem, além de acesso a uma rede que se convencionou chamar “de computadores”, por meio da qual podemos ler notícias, "baixar" músicas, localizar serviços, conversar, assistir a filmes, entre outras coisas. Ainda, o microcomputador, o Ipad, os livros eletrônicos e as câmeras portáteis ampliam o espectro de meios de comunicação audiovisuais possíveis.

A partir do raciocínio de Torloni, os novos aparatos multiplicariam as ameaças ao hábito de ler livros. Na trajetória estabelecida por ele, inclusive, tal prática já teria caído em desuso. Afinal, desde então, a proximidade com os meios de comunicação, especialmente se levarmos em conta a população jovem, só fez aumentar. Mas, de acordo com estudos realizados por autores como Barbero, Orozco e Canclini, entre outros, ao contrário do que se supôs esta interação tem 
permitido uma nova forma de aprendizado, em que o próprio usuário/audiência/ouvinte/internauta/leitor é receptor, mas também emissor de informações, adapta-se e desenvolve novas linguagens e adquire conhecimento se divertindo.

Os novos recursos de comunicação possibilitam também múltiplas leituras. Não seria absurdo afirmar que eles representam formas variadas de contato com a palavra escrita e, talvez, de uma maneira como nunca se viu antes. As mensagens de texto por celular, os sítios na internet, os tweets, os posts, os recursos dos aplicativos de mensagens instantâneas como os chats e o Messenger, os jogos eletrônicos e as pistas distribuídas em complexos cenários virtuais, com direito a charadas a serem resolvidas.

Naturalmente estas modalidades de leitura não substituem aquela que se realiza por meio dos livros. Esta requer maior dedicação ao universo construído em torno de uma obra e representa o potencial de experiências leitoras mais profundas e detalhadas. Não parece despropositado, contudo, considerar possível a passagem das primeiras (leitura dos meios de comunicação) para a última (leitura de livro, em especial o literário) por meio de estratégias que envolvem a escola e os educadores.

Em associação aos fatores cognitivos e às novas formas de leitura oferecidas por estas linguagens e aparatos, achamos oportuno mencionar o papel dos meios de comunicação no cotidiano social, nas vivências no interior das comunidades. Desde Gramsci, mas de maneira mais incisiva a partir de autores como Hoggart (2009), Williams (2000) e Hall (2006), os conceitos de cultura maior e cultura menor foram relativizados. Os autores citados estabeleceram uma concepção de cultura como atividade orgânica, cooperativa e colaboracionista, resultante das vivências cotidianas, no interior da qual se formam e consolidam os traços identitários. Segundo eles, os hábitos, o comportamento social e as experiências históricas permitem aos indivíduos se reconhecerem e, consequentemente, se inteirarem de um processo de aprendizagem que é mais efetivo por levar em consideração o significado daquilo que está sendo apreendido.

Em outras palavras, os livros, que representam o popular e, por exemplo, são sucessos de vendas - mas não necessariamente de crítica -, muitas vezes são 
adaptados para o cinema, ganham versão pirata na internet, abastecem hotsites, se reconfiguram em formatos para o videogame ou se transformam em notícia de rádio, televisão ou para o meio impresso e passam a representar elementos da cultura comum; nela, o leitor/audiência encontra um lugar. O ponto principal é que, por se tratar de ambiente onde o jovem se reconhece, pode também representar uma fonte potencial de aprendizagem.

Por esta abordagem, parece fundamental estimular a diversificação e o aprimoramento das práticas. O desenvolvimento do hábito de leitura de livros é contínuo e quanto menos estranhos à realidade do formando e mais prazerosos forem os meios de aquisição maiores serão as chances de se atingir os objetivos propostos.

Como salienta Gómez Orozco, está cada vez mais generalizada uma forma bastante popular de produzir, reproduzir e disseminar cultura por intermédio dos meios de comunicação, como a televisão e aparelhos celulares. "Habrá que agregar que las nuevas estéticas de las visualidades que se producen, intercambian y consumen las pantallas, además, conllevan elementos lúdicos.” (2004:16)

Somada ao fato de que se tratam de maneiras de produzir cultura e se manifestam em um ambiente lúdico, a ideia de que os meios de comunicação contam com um perigoso efeito narcotizante e manipulador não é única. Os leitores (e audiências) não são meramente passivos e nem absorvem sem imprimir sua própria individualidade às mensagens. Mais que isso, são editores, revisores e produtores.

O desafio é identificar em que medida estas leituras transversais entre meios de comunicação, que não são capazes de substituir umas às outras (CANCLINI, 2008:29), podem se completar. O interesse despertado por determinada mensagem ou conteúdo, a partir de uma plataforma específica, transferido para outra, que requer experiências cognitivas diferenciadas, ora sintetizando, ora aprofundando, de maneira a promover uma aprendizagem mais ampla e complexa. 


\subsection{Críticas atuais}

Mark Bauerlein (2008) está entre os críticos atuais da internet, do apelo à imagem e das transformações provocadas pela fragmentação. Em seu polêmico livro The Dumbest Generation - How the digital age Stupefies Young americans and jeopardizes our future, ele apresenta um prognóstico apocalíptico do futuro. Segundo ele, estaríamos todos “emburrecendo" e os jovens, por manterem uma relação de maior afinidade com as novas tecnologias, ou seja, jogarem videogame, acessarem internet e utilizarem seus recursos em sua potencialidade máxima, enfim, blogarem, twittarem, teclarem..., seriam os mais afetados. Eles estariam literalmente se tornando uma "geração de estúpidos” e a perspectiva seria a pior possível diante deste cenário.

Segundo Bauerlein, algumas características das novas linguagens, como a não linearidade, velocidade, privilégio aos sons e imagens em prejuízo do conteúdo escrito, estariam comprometendo algumas habilidades "essenciais”, por exemplo a concentração e o raciocínio em profundidade, e desestimulando a leitura de livros. O autor utiliza como referência estudos desenvolvidos pelo instituto Nielsen - as pesquisas apontam que os internautas são movidos pela curiosidade e, portanto, acessam diferentes páginas e transitam com bastante facilidade entre elas, são capazes de registrar imagens e cores, adaptam-se com facilidade aos diferentes leiautes e às estruturas das ferramentas disponibilizadas via web, entretanto, pouco absorvem do conteúdo visto.

Este fenômeno foi chamado pelo autor de escaneamento. A exemplo do que ocorre quando se utiliza um scanner, as pessoas que acessam sítios na internet gravam no cérebro apenas uma "imagem” do que viram e são incapazes de lembrar o que haviam lido instantes atrás. A partir desta concepção, não haveria uma leitura efetiva do conteúdo.

"Only 16 percent of the subjects read text on various pages linearly, word by word and sentence by sentence. The rest scanned the pages, 
'picking out individual word and sentences,' processing them out of sequence. The eyetracker showed users jumping around, fixating on pieces that interest them and passing over the rest." (BAUERLEIN, 2008:143)

Outro trabalho citado por Bauerlein trata especificamente do videogame. Desenvolvido pela Federation of American Scientists, o estudo analisou os jogos populares entre os adolescentes e revelou que alguns dos games complexos podem, de fato, ensinar ou contribuir para o desenvolvimento de habilidades específicas de raciocínio, como análise interpretativa, resolução de problemas, formulação e execução de planos e adaptação a rápidas mudanças. Entretanto, tais "virtudes" foram identificadas apenas em alguns dos aplicativos. Os resultados indicam que a maioria deles caminha justamente em direção oposta. Vale-se de um vocabulário pobre e não explora competências numéricas. Além disso, o pesquisador americano pondera que mesmo os melhores exemplos teriam alcance limitado e que as influências positivas impactariam em apenas parte dos aspectos da aprendizagem.

Umberto Eco também vê com cautela especialmente a internet, parte de seus recursos e a saturação de conteúdo a que somos submetidos em tempo real, 24 horas por dia. Em entrevista concedida a Cruz, originalmente publicada no El País e posteriormente reproduzida de forma parcial no caderno Mais! do jornal Folha de S. Paulo, o pensador italiano aponta a dificuldade de se distinguir o verdadeiro do falso e a perda da memória como duas das principais interferências negativas da versão online do mundo:

“(...) parece que tudo é certo, que você dispõe de toda a informação, mas não sabe qual é confiável e qual é equivocada. Essa velocidade vai provocar a perda de memória. E isso já acontece com as gerações jovens, que já não recordam nem quem foram Franco ou Mussolini! A abundância de informações sobre o presente não the permite refletir sobre o passado (...)." (CRUZ, 2008) 
Em artigo recente, publicado no The New York Times, Eco retorna ao assunto em uma análise do Wikipédia. Depois de apontar alguns dos aspectos positivos da ferramenta, que permite às pessoas que têm acesso a ela realizar um trabalho coletivo, que envolve milhões de mãos, corrigindo informações falsas ou fazendo complementações, ele pega o próprio exemplo para refletir sobre as deficiências do mecanismo. Cita algumas das distorções verificadas no seu perfil na enciclopédia virtual, obviamente editado por alguém que não o conhece. Só para ficar em duas delas, ele teria se casado com a filha de um ex-chefe e seria o mais velho de treze filhos.

Ao fazer tal abordagem, o pensador explica que um pesquisador experimentado dificilmente se deixará enganar por dados desencontrados. Esperase que ele consulte mais de uma fonte e faça comparações antes de fazer uso de dado conteúdo. Mas, se levado em consideração o fato de que a grande maioria dos usuários não se enquadra neste perfil e que muitos deles, inclusive, são jovens em idade escolar, em busca de material para elaborar seu trabalho, pode-se calcular as dimensões do problema.

Aí parece haver um nó difícil de desatar. Pelo menos em sua forma atual, a internet tende a ser um meio impossível de se administrar. O conteúdo abundante é, sem dúvida, o principal complicador. De resto, consideramos temeroso admitir esta possibilidade de controle, dado o risco de se descaracterizar um meio que teria nascido para ser aberto. Em todo o caso, o que fazer?

Não é demais salientar, entretanto, que os meios de comunicação não foram concebidos para educar e sim para entreter (GÓMEZ OROZCO, 2008). Sua apropriação com tal objetivo sempre exigirá um processo de adaptação. Intercorrências como as relatadas por Eco e Bauerlin não são episódicas, mas, ao contrário, representam ameaças, que podem anular o potencial já mencionado dos meios de comunicação.

Cabe atentar ao processo de recepção e fazer valer o papel de mediadores que têm condições de exercer tanto pais quanto professores. Saber aproveitar a facilidade que os jovens dispõem de se inteirar com tais aparatos, aprender com eles 
a utilizar tais linguagens e identificar caminhos que permitam a convergência entre novas e antigas formas de aprendizagem.

Ao mesmo tempo em que já é difícil imaginar um modelo unidirecional, calcado apenas em padrões tradicionais, no qual em uma ponta estão os mestres condutores e na outra os aprendizes, também não é razoável admitir que se trate de uma atividade solitária. Ao contrário, talvez a função intermediária dos educadores se torne cada vez mais importante, pois é provável que, com o barateamento dos suportes e tecnologias, um número cada vez maior de pessoas se insira no mundo das comunicações e cada vez mais precocemente.

Para que a aprendizagem ultrapasse os limites do superficial e não se transforme em uma espécie de conhecimento instável, efêmero e que pouco contribua para o desenvolvimento intelectual dos alunos, como explanado pelos autores citados, é fundamental estabelecer este cruzamento entre diferentes saberes. Aproveitar as potencialidades dos media, sem abrir mão de outros recursos, como o exercício de processos cognitivos que permitem a reflexão mais profunda.

"Con base en lo anterior es urgente replantear la recepción. Los programas televisivos no problematizan por sí mismos y la recepción solitaria refuerza un aprendizaje referencial, simple y superficial, lo cual redunda em las estructuras cognitivas de los niños. Es indispensable el apoyo de padres y maestros para pasar del realismo nominal a la simbolización como una forma de distanciamiento, em aras de colaborar em la construcción interna y externa del sujeto. Para superar el aprendizaj $\quad e$ bajo um mínimo esfuerzo mental deben ejercitarse algunos procesos cognitivos tales como identificar intertextualidades o tejer redes de significado, por ejemplo. Asimismo, es relevante trascender planteamientos dicotômicos, los cuales no propician um pensamiento crítico ni uma explicación compleja de la realidad.” (GONZÁLES, 2004:133-134) 
A Sala de Leitura, foco desta pesquisa, parece um ambiente propício para tais manifestações. Uma vez que nestas aulas os alunos têm maior liberdade para interagir com colegas e professores, assim como não há exatamente um conteúdo programático e sistema de notas, podem experimentar uma habilidade historicamente desfavorecida (é o caso da leitura) a partir de estímulos do cotidiano. Nesta perspectiva, o educador também tem maior liberdade para explorar temas recorrentes no dia-a-dia dos jovens e intermediar o contato entre os estudantes e as páginas que ainda estão por ser descobertas.

Mais do que abordar autores e obras muito comentados nos meios de comunicação, o professor poderia aproveitar o que pode existir de complementaridade nesta relação. Recorrer a romances que tratam da era medieval para fazer uma releitura do game de RPG que é mania entre os estudantes. Sugerir a leitura de determinados poetas que inspiram a banda de rock mais ouvida. Promover sessões de leitura de trechos de obras que tratam da questão do deficiente como forma de aproveitar um tema explorado nas telenovelas.

Não pretendemos assumir uma postura prescritiva com tais ponderações. Nossas contribuições buscam sugerir alternativas, instrumentos, recursos, meios de ampliar o debate e, em confluência com a ideia dos autores pesquisados, estabelecer conexões entre o ambiente educacional com o qual os estudantes mantêm um convívio diário e as práticas e experiências individuais. 


\section{MEIOS DE COMUNICAÇÃO E OPORTUNIDADES DE LEITURA}

Em meados da década de 70, Alan Swingewood lançou $O$ mito da cultura de massa, uma obra que se contrapunha à corrente crítica da comunicação, principalmente aos frankfurtianos. Na contramão dos principais teóricos de sua época, ele apresentou uma perspectiva otimista em relação aos meios de comunicação, relacionando benefícios e pretensas contribuições para o desenvolvimento social e econômico.

Àquela altura os media já estavam consolidados e haviam ampliado não apenas a abrangência como também a diversificação dos serviços: as antenas multiplicadas, lançamento dos primeiros satélites, a possibilidade cada vez maior de se captar ondas curtas e médias, imagem colorida, além da revolução da informática em curso.

Ao resgatar as ideias de diferentes estudiosos ao longo dos últimos dois séculos, além da vertente inspirada na crítica marxista, sobretudo materializada na Escola de Frankfurt, Swingewood, embora não compartilhasse da mesma compreensão, expôs o ideal defendido por aqueles que se guiavam pelas referências aristocráticas, visivelmente identificadas com uma posição saudosista, apoiada em uma leitura do mundo que elege certos ideais do passado como padrões a serem seguidos.

Entre os primeiros defensores deste entendimento estava Friedrich Nietzsche. Além de alimentar boas lembranças em relação ao "passado promissor”, com a valorização da nobreza e seus preceitos, ele não deixava de manifestar preocupação quanto ao rebaixamento ao qual se sujeitavam os verdadeiros merecedores do papel de condutores do desenvolvimento da humanidade. Rebaixamento, que, no seu entendimento, se traduzia em perigo iminente.

"Para Nietzsche, como para os críticos conservadores do século XIX, como T.S. Eliot e Ortega y Gasset, a ameaça à sociedade moderna vem "de baixo", do "homem comum", do "homem da 
massa”, que tem que ser ensinado para conhecer o seu lugar natural (...). Mas, para Nietzsche, o principal problema é que o homem comum, o medíocre, nem sempre se contenta com o status social que lhe é destinado.” (SWINGEWOOD, 1978:7-8)

Na opinião do pensador alemão, esta condição de vulnerabilidade permitia que o "homem comum" se tornasse "presa fácil" dos ideais socialistas. Principalmente o movimento sindical e o discurso de igualdade transformariam o operário, suscitariam novos desejos, teriam o poder de despertá-lo de sua existência menor, "que o torna invejoso, que lhe ensina a vingança." (1978:8)

Swingewood discorda tanto de marxistas quanto de aristocratas. Para ele, não se trata de um cenário catastrófico que se apresenta nos tempos modernos. Ao contrário, a introdução dos meios de comunicação de massa teria contribuído para que se alcançasse uma série de conquistas sociais sem precedentes na história da humanidade. Composta por uma "sociedade pluralista", nossa época seria marcada pelo maior equilíbrio entre as classes, sem o pleno domínio de uma em relação às demais, pela sustentação de hábitos mais democráticos, com uma quantidade cada vez maior de pessoas tendo acesso à educação e cultura, de maneira que não seria de todo absurdo afirmar que, nos dias de hoje, constata-se a universalização de certos privilégios antes restritos a uma pequena e abastada minoria.

“A sociedade é, então, uma estrutura complexa de controles e equilíbrios em que nenhum grupo galga a um poder dominante. (...) $\mathrm{Na}$ sociedade pluralista, portanto, a vida é fortalecida, e não empobrecida, pois a vasta massa da população, pela primeira vez na história humana, se integra numa cultura de massa democrática: no passado, uma população quase que de todo analfabeta nada lia e apenas uma pequena fração das classes superiores participava das atividades culturais.” (1978:19) 
O autor de O Mito da Cultura de Massa não é voz solitária em suas ideias controversas acerca dos benefícios da sociedade de massa, bem como no digladiar contra o discurso dominante sobre potenciais prejuízos e um futuro pessimista. Em A sociedade de Massa e sua Cultura, Edward Shils, ainda que de forma mais contida, aponta “facilidades” obtidas em período posterior à revolução industrial. Os principais favorecidos teriam sido os ocupantes das classes baixa e média.

Valendo-se de um trecho da obra de Shils, Waldenyr Caldas aborda exatamente esta perspectiva positiva desenvolvida pelos adeptos do "evolucionismo progressista”. O autor aponta que, ao longo do século XX, um número cada vez maior de pessoas, especialmente entre as classes menos favorecidas economicamente, passou a ter acesso à cultura, ao conhecimento e a novas oportunidades de emprego. Neste contexto, as camadas sociais antes relegadas à ignorância, sem possibilidades mínimas de entretenimento, graças à suposta democratização oferecida pelos meios de comunicação puderam se beneficiar de recursos e privilégios exclusivos dos ricos.

“Não é necessário andar muito para encontrar os motivos deste incremento. Os mais óbvios são: a maior disponibilidade, mais tempo livre, menos exigências físicas de trabalho, o melhoramento econômico das camadas que outrora trabalhavam muito duramente e durante muitas horas com um salário baixo, o maior alfabetismo, o reforço dos valores individuais e uma mais livre $e$ despreconceituada alegria de viver. Em tudo isto, as classes médias e baixas têm ganho mais do que as elites (incluindo nestas os intelectuais), qualquer que seja a sua distribuição profissional." (CALDAS, 2000:43)

Observa-se, a partir deste ponto de vista, que argumentar pura e simplesmente contra os meios de comunicação de massa e sua capacidade de transformar a sociedade, mencionando um possível caráter destruidor, "representa uma visão insensível e insensata do passado e uma gritante acusação da abordagem idealista literária da cultura.”(1978:27) 
À parte os excessos presentes na concepção de autores como Shils e Swingewood, a contraposição à opinião dos frankfurtianos e demais opositores aos meios de comunicação representa a minimização de uma perspectiva que prevaleceu por muitos anos, de que eles representam uma ameaça, comprometem o desenvolvimento intelectual, alienam e tornam as pessoas reféns de um comportamento consumista. Novos olhares, de pensadores que entendem os media como possíveis aliados em favor da educação, tomaram força e se corporificaram.

Em Comunicação e Educação - A Linguagem em Movimento, Adilson Citelli (2004) apresenta o resultado de uma pesquisa realizada entre 96 e 98 junto a professores dos ensinos fundamental e médio que pertenciam, em sua maioria, aos quadros de escolas públicas. Dentre as 36 questões aplicadas junto aos docentes, algumas buscavam identificar a opinião deles em relação aos meios de comunicação. Ainda que a amostragem não possa permitir generalizações, ao menos parece indicar certas perspectivas:

- $92,9 \%$ entendem que a escola deve interagir com as diferentes linguagens de comunicação;

- $81,4 \%$ acreditam que a escola não deve afastar do seu espaço de trabalho as linguagens de comunicação de massa;

- $91,8 \%$ sentem necessidade de receber apoio de materiais ou cursos para trabalhar com as linguagens dos meios de comunicação.

Esta concepção representa uma mudança do entendimento do educador acerca do assunto. Não é o caso de se descartar totalmente a concepção cautelosa acerca dos meios de comunicação. Ela é fundamentada em argumentos válidos, que têm seus méritos e fazem sentido. Não podemos ignorar os males e os fatores limitadores a eles associados de maneira justa.

Trata-se, então, de buscar caminhos que permitam educar com os meios, pelos meios e para os meios. Dito de outra forma, talvez possa ser uma das novas atribuições do educador contribuir para o desenvolvimento nos 
leitores/ouvintes/telespectadores/audiências de uma visão crítica frente às mensagens veiculadas no rádio, na televisão, na internet, no videogame, etc.

Em todo o caso, a ideia de um receptor frágil, fácil de manipular, indefeso, fantoche ao bel prazer dos donos das empresas de comunicação, que não reage diante de qualquer conteúdo, sempre condescendente, já não tem mais a força de antes. Sabe-se que o processo comunicativo é bem mais complexo do que esquemas unidirecionais, de ação sem reação. Aquele que recebe, transforma, "reflete e refrata”. Percebeu-se que a mensagem não é mais a mesma ao chegar ao destinatário. Ela muda. Pode, inclusive, ser rejeitada.

Sujeito autônomo, antes de assistir, ouvir e navegar, o homem pensa. Busca satisfação, quer interagir, reafirmar, dar a sua opinião. E com os novos aparatos tecnológicos, que permitem que tudo seja gravado, alterado, que novas ordens sejam estabelecidas, que seja refeito e editado, quem tende a não faltar é exatamente aquela que diziam estar ameaçada: a criatividade.

"De aquella comprensión de la audiencia como um ente pasivo, víctima masiva e ineviable de emisores voraces $e$ incisivos, a audiencias em plural, activas, buscadoras de gratificación, que luego devinieron hiperactivas, aunque no necesariamente críticas, ni capaces de resembantizar los mensajes según sus propias intenciones, al entendimiento de las audiencias que a su vez devienen en emisores, em eso justamente que nunca fueron - pero em lo que todavia sin mucha precisión empiezan a experimentarse -, hay todo um recorrido histórico donde la comunicación há sido a la vez causa y efecto de dominación y emancipación, y de implosiones y explosiones de la capacidad interactiva y creativa de las sociedades de la última centúria.” (OROZCO, 2008:10-11)

Steven Johnson (2005), um conhecido entusiasta da televisão, do videogame e da internet, explora algumas de suas ideias em defesa das novas tecnologias em Surpreendente! A Televisão e o Videogame nos Tornam Mais Inteligentes. Ele não 
se dedica a desconstruir os argumentos favoráveis aos meios tradicionais de aquisição de conhecimento, apoiados, sobretudo, nos livros e na leitura. Ao contrário, reconhece e reforça seus valores.

Sua proposta, na verdade, é mostrar quais habilidades os aparatos eletrônicos podem desenvolver e de que maneira ambas as formas de aprendizagem podem se complementar. Transcendendo os benefícios comumente vinculados a eles, como o raciocínio rápido, a destreza manual e a inteligência visual, Johnson cita a complexidade de determinados games e o exercício de raciocínio necessário para jogá-los, a possibilidade de simular realidades e de confrontá-las de antemão, antes de um contato físico e literal, além, é claro, do indiscutível exercício de cognição. Sobre a televisão, menciona os seriados cada vez mais complexos, com várias tramas acontecendo ao mesmo tempo, as incontáveis referências, o sem número de artifícios iconográficos, com cortes rápidos e associações aceleradas entre imagens e sons, a descontinuidade e não-linearidade, que exigem maior concentração do espectador.

Em dado momento, ao abordar o preconceito que ainda existe em relação aos meios de comunicação audiovisuais, ele propõe ao leitor uma inversão de ordem em relação às descobertas. Sugere que seja imaginado um mundo em que a cultura que prevalece é da imagem, da TV, do videogame, dos aparatos tecnológicos. Nele, as referências atuais para a aquisição de conhecimento seriam consideradas limitadoras do processo evolutivo.

Em seguida, ainda neste suposto mundo, Johnson propõe que se considere o surgimento do livro e que, de uma hora para outra, ele se tornasse mania e, sobretudo, entre os jovens. Diante deste cenário, o autor norte-americano fez uma divertida análise que poderia decorrer do fenômeno:

"Ler livros durante um longo período de tempo atrofia os sentidos. Ao contrário da antiga tradição de videogames - que envolve a criança em um mundo realista e tridimensional repleto de imagens animadas e trilhas sonoras, pilotadas e controladas por meio de movimentos musculares complexos - os livros são simplesmente uma sequência enfadonha de palavras em uma página. Apenas pequena 
parte do cérebro dedicada ao processamento da linguagem escrita é ativada durante a leitura, ao passo que os jogos envolvem uma variedade completa dos córtices sensoriais e motores.

Os livros também têm a capacidade trágica de isolar as pessoas. À medida que, durante muitos anos, os jogos engajaram os jovens em relações sociais complexas com seus pares, juntos construindo e explorando mundos, os livros forçam as crianças a se isolar em um espaço sossegado, excluídas da interação com outras crianças. Essas novas 'bibliotecas' que surgiram nos últimos anos para facilitar as atividades de leitura são uma visão aterrorizante: dúzias de crianças, em geral tão animadas e interativas socialmente, sentadas sozinhas em cubículos, lendo silenciosamente, esquecidas de seus pares." (2005:16-17)

Mais uma vez reforçamos a necessidade de reflexão sobre as amplas oportunidades existentes nos aparatos tecnológicos, aos quais poderíamos acrescentar o telefone fixo e o aparelho celular. A não ser que mudanças radicais aconteçam ao longo dos próximos anos, não é mais possível imaginar o mundo em que vivemos sem a forte presença de tais suportes. Eles vieram para ficar e são aceitos de forma massiva. Resta-nos encontrar meios de torná-los favoráveis a nós. Neste contexto, o professor pode e deve exercer papel fundamental. 


\section{LIVROS AINDA? POR QUÊ?}

\footnotetext{
“- Tão propenso anda o homem a dedicar-se ao que já de mais vulgar, com tanta facilidade se lhe embotam o espírito e os sentimentos para as impressões do belo e do perfeito, que por todos os meios deveríamos conservar em nós essa faculdade de sentir. Pois não há quem possa passar completamente sem um prazer como esse, e só a falta de costume de desfrutar algo de bom é a causa de muitos homens encontrarem prazer no frívolo e no insulso, contanto que seja novo. Deveríamos - dizia ele diariamente ouvir ao menos uma pequena canção, ler um belo poema, admirar um quadro magnífico e, se possível, pronunciar algumas palavras sensatas." (Goethe, Os anos de aprendizagem de Wilhelm Meister)
}

Sabe-se que a quantidade de obras literárias (romances, contos, poesias...) lidas no Brasil, sobretudo se consideradas as versões impressas, é pequena. É preciso reconhecer o quanto o livro é valorizado e cultuado. Com relativa frequência, ele se transforma em item decorativo, inclusive na condição de falso livro - nas estantes, os volumes -, e talvez não haja clichê maior - nas orelhas das capas de algumas publicações do que a foto básica do autor com a biblioteca pessoal ao fundo.

Uma pessoa com livro nas mãos é vista com admiração. Quem lê muito é tido pelos outros como inteligente. Às vezes é presenteado com alguns adjetivos menos lisonjeiros como cdf, nerd, caxias, mas nada que se compare a burro, estúpido, ignorante. Para o bem ou para o mal, o leitor inveterado é sempre tido como um “intelectual”.

A mãe zelosa não perde a oportunidade de se agastar com o filho que passa horas jogando videogame, assistindo à televisão ou na internet. Agora, tudo indica que seria improvável que as mesmas queixas se dirigissem ao filho que resolveu utilizar a mesma quantidade de horas lendo um livro. Na verdade, reclamações se transformariam em motivo de orgulho. "Esse meu filho vai longe!" 
Um primeiro aspecto que convém mencionar é que a leitura sempre esteve vinculada à ideia de aquisição do conhecimento. Como indica o trecho de Os anos de aprendizagem de Wilhelm Meister posto acima, no diálogo de Serlo com o protagonista daquele que é considerado o primeiro romance de formação ${ }^{8}$, o ator afirma que apreciar a arte, seja qual for sua manifestação, é maneira de trabalhar a sensibilidade, de conhecer a si mesmo e ao mundo, de manter o devido distanciamento da vulgaridade que é tão característica ao cotidiano.

Um segundo ponto que deve ser considerado guarda relação com a possibilidade que a leitura nos oferece de nos colocarmos no lugar do outro. Ela permite a ampliação de nossa visão sobre o mundo sem que tenhamos necessariamente de vivenciar tais experiências: viver dramas e angústias alheias, ser pirata ou milionário, frequentar grandes festas ou presenciar brigar homéricas. A leitura abre portas para realidades paralelas.

A capacidade de transcendência proporcionada pela leitura de livros é mencionada ou discutida na obra de autores como Jouve, que, ao retomar ideias de Jauss e sua "estética da recepção", reafirma o potencial transformador da obra literária.

"Para retornar os termos de Jauss, a leitura, como experiência estética, é, portanto sempre 'tanto libertação de alguma coisa quanto libertação para alguma coisa'. Por um lado, ela desprende o leitor das dificuldades e imposições da vida real; por outro, ao implicá-lo no universo do texto, renova sua percepção do mundo.” (JOUVE, 2004:108)

Inspirada nesta concepção, a Universidade Federal de São Paulo (Unifesp) desenvolveu um projeto que tinha o objetivo de despertar, a partir da leitura de livros, o olhar mais humanizado em alunos e funcionários acerca de sua profissão e de seu papel na sociedade. Matéria publicada no jornal O Estado de S. Paulo, de 25

\footnotetext{
${ }^{8}$ Aliás, o romance de formação talvez seja a expressão máxima desta ideia de função humanizadora da leitura.
} 
de outubro de 2009, descreve aspectos do trabalho, que consistiu na formação de uma roda de discussão em torno de obras literárias. Os participantes eram convidados a se interarem de títulos os mais variados, como O Senhor dos Anéis, Primeiras Estórias, O Apanhador no Campo de Centeio e Odisséia e, em seguida, participavam de um debate. A ideia de aguçar a sensibilidade dos profissionais de saúde e promover melhorias na qualidade da relação com os pacientes por intermédio do livro despertou o interesse de um número tão grande de pessoas que a instituição decidiu transformá-la em curso de pós-graduação.

Uma terceira questão que gostaríamos de introduzir no presente capítulo é o declínio sofrido pelo ideal humanista ao longo do século XX e seus impactos sociais. Associadas às transformações provocadas especialmente pelo surgimento dos meios de comunicação, críticas ao seu caráter elitista ganharam coro ao longo das últimas décadas. Como pondera Dussel (2009), sobretudo a "ação escolar" sofreu fortes abalos por excluir a cultura popular, a cultura contemporânea e os produtos da indústria cultural, além de ignorar o papel dos jovens e suas manifestações particulares.

No campo específico da literatura, ocorrem as classificações como alta literatura, erudita, paraliteratura, subliteratura, literatura marginal, literatura popular. Conceituações mais radicais dão conta de polarizações como nobre e lixo. O primeiro recomendado para qualquer um que queira elevar o espírito, realizar uma viagem de autoconhecimento em favor da intelectualização do indivíduo. O último seria material de segunda categoria, criado apenas para entreter, sem grandes aspirações para contribuir com o aprendizado.

Para Márcia Abreu, é preciso tomar tais considerações com parcimônia. A visão dos especialistas em crítica literária não deveria ser considerada como única e verdadeira. Os fatores culturais, as experiências individuais, o momento histórico são aspectos que devem ser incluídos nesta equação. Ainda que haja todo um trabalho de pesquisa desenvolvido, independe das produções científicas que indicam determinados caminhos e compreensões, cabe admitir tais produções como um ponto de vista entre inúmeros outros. Concepções distintas não podem ser ignoradas, pois também se baseiam em uma lógica (ainda que possam parecer 
ilógicas a partir de certos critérios, como os utilizados por um crítico literário) e fazem sentido no interior de seus próprios jogos particulares.

"Ao tratar de literatura e de valor estético, estamos em terreno movediço e variável e não em terras firmes e estáveis. O que se considera literatura hoje não é o que se considerava no século XVIII; o que se considera uma história bem narrada em uma tribo africana não é o que se considera bem narrado em Paris; o enredo que emociona uma jovem de 15 anos não é o que traz lágrimas aos olhos de um professor de 60 anos; o que um crítico literário carioca identifica como um uso sofisticado de linguagem não é compreendido por um nordestino analfabeto. O problema é que o parisiense, o professor, o crítico literário, o homem maduro têm mais prestígio social que o africano iletrado, a jovem, o lavrador. Por isso conseguiram que seu modo de ler, sua apreciação estética, sua forma de se emocionar, seus textos preferidos fossem vistos como o único (ou o correto) modo de ler e de sentir.” (2006:58)

A autora acredita, no entanto, que a transformação da literatura em disciplina escolar permitiu que a mencionada categorização se acentuasse. Mais do que isso, contribuiu para que se propagasse a ideia por intermédio da qual a chamada Grande Literatura deixou de ser vista como "algo particular $e$ historicamente determinado" e se tornou um patrimônio universal, que se mantém estável independentemente de qualquer barreira temporal, um bem capaz de ser interpretado por qualquer um da mesma forma, não obstante as condições em que se dê a recepção da obra universal.

Antonio Candido, em A Literatura e a Formação do Homem, acrescenta um novo ingrediente à discussão acerca do "papel humanizador” da literatura. Apesar de defensor dos livros como potencial transformador, como meio pelo qual podemos aprender e desenvolver nossas capacidades de lidar com o mundo, no entendimento do intelectual, ele [o livro] contaria com uma ligeira autonomia na 
pretensa (ou não pretensa) iniciativa de formar, o que, a princípio, entraria em conflito com a "pedagogia oficial”, pelo menos de maneira parcial.

Por retratar a vida nos contextos possíveis, a partir de suas diferentes faces, a obra literária se desloca do ideal fortemente atrelado à "tríade famosa - o Verdadeiro, o Bom e o Belo", que se faz presente no discurso escolar, para provocar uma experiência educativa de natureza diversa. "Daí as atitudes ambivalentes que suscita nos moralistas e nos educadores, ao mesmo tempo fascinados pela sua força humanizadora e temerosos de sua indiscriminada riqueza.” (1999:83)

Passados quase 40 anos, muito do que o texto discute ainda é atual. A própria repercussão do episódio em torno dos livros adquiridos pela Secretaria de Educação do Estado de São Paulo em 2009 parece ir ao encontro das reflexões de Candido. As reclamações acerca da existência de palavrões, gírias e palavras chulas em determinadas obras ou mesmo a contrariedade em relação aos temas abordados são bons exemplos neste sentido. Independentemente do mérito das queixas (de serem justas ou não), é fato que os títulos estão em conflito com os projetos pedagógicos e, mais que isso, nem sempre estão totalmente sintonizados com o próprio entendimento que a sociedade tem sobre o papel do livro no processo de educação.

"Paradoxos, portanto, de todo lado, mostrando o conflito entre a ideia convencional de uma literatura que eleva e edifica (segundo os padrões oficiais) e a sua poderosa força indiscriminada de iniciação na vida, com uma variada complexidade nem sempre desejada pelos educadores. Ela não corrompe nem edifica, portanto; mas, trazendo livremente em si o que chamamos o bem e o que chamamos o mal, humaniza em sentido profundo, porque faz viver.” (1999:88)

A relativização deste referencial humanista suscita alguns questionamentos. Seria correto afirmar que a leitura perde espaço e importância à medida que tais verdades universais têm seu sentido comprometido e não há condição de se eleger 
determinadas obras como indiscutíveis, inquestionáveis, inabaláveis? Em que o livro pode se diferenciar de outras formas de leitura a ponto de continuar a ser uma prática válida, distinta de outra mania qualquer dos colecionadores ávidos por coisas antigas? Não seria o mesmo que preferir a máquina de escrever ao computador? Ou o carburador à injeção eletrônica? Afinal, os recursos audiovisuais, a tecnologia, os meios de comunicação oferecem centenas de milhares de outros estímulos.

Aqui vale retomar Jouve (2004) e sua forma de se referir aos livros. A possibilidade de criar um livro novo, a oportunidade de se libertar de alguma coisa ou para alguma coisa, a “identificação 'espontânea'” com histórias e personagens, o estímulo à imaginação, a experiência enriquecedora obtida a partir do "autodistanciamento", a semelhança "entre o estado de leitura e o sono", o exercício da imaginação e o preenchimento dos “ “vazios’ do texto”.

Outro autor que explora com propriedade tais experiências, com especial interesse sobre os “vazios” preenchidos pelo leitor, é Jauss. Na obra A História da Literatura como Provocação à Teoria Literária, ele menciona o "saber prévio", antes mesmo de iniciar as primeiras linhas, as vivências pessoais, a história de vida, “com base no qual o novo que tomamos conhecimento faz-se experienciável”. Há “um horizonte de expectativa”, uma predisposição do público, que “desperta a lembrança do já lido”.

O livro não é a única maneira, mas uma delas e com uma forma toda particular, individual, libertária, de renovar a relação do leitor consigo mesmo. E se nem sempre este contato vai se converter em aquisição de conhecimento, no mínimo manterá permanentemente vivo o interesse de quem lê para com o que a página seguinte guarda de novo, de expectativa, de futuro.

“A experiência de leitura logra libertá-lo das opressões e dos dilemas de sua práxis de vida, na medida em que o obriga a uma nova percepção das coisas. O horizonte de expectativa da literatura distingue-se daquele da práxis histórica pelo fato de não apenas conservar as experiências vividas, mas também antecipar possibilidades não concretizadas, expandir o espaço limitado do 
comportamento social rumo a novos desejos, pretensões e objetivos, abrindo assim, novos caminhos para a experiência futura.” (JAUSS, 1994:52)

A esta altura, parece oportuno retomar a trajetória realizada a partir do quinto capítulo. Em Correntes críticas: meios de comunicação e leitura literária, procuramos expor as ideias e estudos contrários aos meios de comunicação, que os consideram uma ameaça e prejudiciais à leitura de livros. Em Meios de comunicação e as oportunidades de leitura, a intenção foi retomar conceitos e autores que propõem o caminho contrário, isto é, sugerem que os media sejam vistos como aliados no processo de educação.

E, finalmente, em Livros ainda? Por quê?, a proposta foi abordar teóricos que argumentam em favor da literatura, que apresentam razões para que o romance, o conto e a poesia, por exemplo, sejam frequentados com maior assiduidade e interesse. A intenção era apontar referências que pudessem mostrar se este tipo de leitura ainda poderia ser importante e necessário nos dias de hoje, um período marcado pelo privilégio ao movimento, ao som, à imagem, à fragmentação, ao digital, ao virtual.

Afinal, há espaço para os livros ainda? Jouve, Jauss, Dussel, Abreu e Candido, entre outros, não apenas demonstram que sim como também indicam que o espaço ocupado pela obra literária não pode ser substituído, da mesma forma que ela também não é capaz de preencher aquele que é próprio do rádio, da TV, da internet, do videogame. Esta relação, portanto, deve ser de complementaridade.

Mais uma vez, retomamos o conceito de leituras híbridas. A possibilidade de visitar diferentes linguagens e de experimentá-las dentro de suas particularidades, das sensações que elas nos oferecem. Enfim, o potencial de descoberta existente nesta variedade de plataformas, que nos permite estar em contato com um sem número de perspectivas e realizar esta diversidade de leituras por intermédio dos diferentes órgãos dos sentidos. 
Reafirmamos a consciência a respeito de nossas limitações e de nosso papel, bem como do alcance da presente pesquisa. Não somos especialistas da área de leitura e literatura e, também por este motivo, não pretendemos debater aqui questões e conceitos em torno do assunto. Associadas ao fato de nos faltar conhecimento suficiente para tal incursão, nossas pretensões estão direcionadas prioritariamente a localizar pontos de interseção entre medias e livros de forma que os primeiros possam facilitar o acesso aos últimos, sendo irrelevante para o escopo deste trabalho avaliar, classificar e distinguir os conteúdos.

O presente capítulo tinha o propósito de relacionar pontos que validam a leitura de livros como forma de aquisição do conhecimento e desenvolvimento da capacidade intelectual. O aprimoramento das sensibilidades, a oportunidade de se colocar no lugar do outro, de resgatar nossas próprias experiências, de ocupar os vazios, de desenvolver nossos caminhos, visões e perspectivas, de entrar em contato com outras culturas e conhecimento estão entre as possibilidades e permissões oferecidas por ela.

Somos favoráveis ao argumento que atribui ao livro e, por consequência, à leitura posição de protagonista no processo de letramento, que é a base da educação formal. E acreditamos que por intermédio da educação o homem conquista o desenvolvimento pessoal, amplia seu leque de oportunidades (de emprego, de relações sociais, de conhecimento...) e pode fazer valer sua condição de cidadão.

A miríade de ideias e conceitos aqui apresentados busca ratificar tal entendimento e, mais uma vez, ponderar que, quando associada às vivências e experiências pessoais, a prática leitora se reveste de sentido. O leitor que quer se espelhar, que deseja se colocar em condições de comparação, que busca se reconhecer, independentemente dos meios e das linguagens aos quais tem acesso (livro, televisão, rádio, internet, videogame, computador...) pode experimentar na palavra escrita, a exemplo do que ocorre com os meios audiovisuais aos quais ele não parece se opor, formas que reconhece, aceita e partilha de contato com o mundo. 


\title{
10. METODOLOGIA DE PESQUISA
}

\author{
"Que isso de método, sendo, como é, uma coisa \\ indispensável, todavia é melhor tê-lo sem gravata nem \\ suspensórios, mas um pouco à fresca e à solta, como quem \\ não se lhe dá da vizinha fronteira, nem do inspetor de \\ quarteirão.” \\ (Memórias Póstumas de Brás Cubas, Machado de \\ Assis)
}

Utilizamos a etnografia como metodologia de pesquisa do presente trabalho científico. Em função dos desafios estabelecidos pelo problema, assim como dos objetivos decorrentes, entendemos que os caminhos recomendados por esta abordagem seriam os mais adequados para atingir os propósitos que orientam nossa pesquisa. Visto que o interesse é verificar se os meios de comunicação audiovisuais, especialmente a televisão, o rádio, o videogame, a internet e o aparelho celular, entre outros, podem de alguma forma contribuir para aproximar os jovens dos livros, pareceu-nos que uma estratégia que se direcionasse, como afirma Chizzotti, à "descrição ou reconstrução de mundos culturais originais de pequenos grupos” (2010:71-72) atenderia às demandas e necessidades aqui definidas.

Nossas expectativas se direcionavam à escola. De maneira mais específica, aos alunos e ao professor de sala de leitura de uma unidade escolar. Buscávamos um instrumento para a realização da atividade de campo que nos permitisse ser o menos invasivos possível. Isto é, que preservasse ao máximo o comportamento da população que constitui a nossa amostragem e que, portanto, proporcionasse a desejada compreensão acerca da possível relação entre os media e o interesse pelos livros. O nosso entendimento era que determinadas abordagens, nas quais os 
participantes são incitados a responder ao pesquisador, resultariam na perda da espontaneidade.

Neste contexto, a constatação da circulação (ou não) do discurso comunicacional no ambiente escolar deveria ser verificada in loco, por meio da observação das idiossincrasias, das particularidades que são próprias daquele dado ambiente escolar. Realizar uma entrevista, aplicar um questionário ou promover uma discussão em grupo para verificar, por exemplo, se os alunos e/ou o professor conversam durante as aulas a respeito de determinado programa de televisão, se fazem reverberar a experiência em relação ao game novo para Playstation 3, se discutem a última rodada do Campeonato Paulista, se dialogam acerca de aplicativos para celulares ou computadores parecem estratégias pouco funcionais e infrutíferas para o escopo da nossa pesquisa.

Mais do que isso, tentar validar por intermédio destes recursos uma possível relação entre estes diálogos fundados na potencial circularidade comunicacional e a aproximação (ou interesse) dos estudantes por determinados títulos ou obras nos pareceu ainda menos efetivo. Em que bases se daria esta tentativa de captação? Através de questões abertas e/ou fechadas? E como seria possível concebê-las? Formular uma pergunta do gênero "de que maneira você seleciona os livros que você lê?”, ou ainda, “aquilo que você vê na televisão faz com que você escolha determinado título?”, por exemplo?

Procuramos nos afastar de propostas como estas pelo temor de abrir mão daquilo que Bourdieu chama de vigília epistemológica. Ainda que determinadas alternativas pudessem representar maneiras mais objetivas, mais rápidas e, talvez, até passíveis de generalizações, acreditamos que poderíamos cometer o equívoco que o autor francês crê ser comum em certas pesquisas "concebidas como prova lógica ou metodológica”, que, a exemplo daquilo que afirma Abraham Kaplan citado pelo referido autor, parece se aproximar da "conduta do ébrio que, tendo perdido a chave de casa, procura-a obstinadamente ao pé de um lampião sob o pretexto de que aí está mais claro”. (1999:18)

Ao resgatar nosso problema de pesquisa e o percurso teórico ao qual ele nos incitou, concluímos que o estudo etnográfico é, portanto, aquele que mais se ajusta 
aos nossos anseios, às nossas interrogações ou, ainda, nos oferece mais possibilidades de multiplicar as incertezas próprias da descoberta.

O levantamento de informações naturalmente se estruturou com base nas propriedades desta proposta metodológica, que entre outras coisas, como destaca Chizzotti, admite um pequeno grupo, para a realização de um estudo em profundidade, considerando hábitos, práticas e as especificidades, evitando, na medida do possível, os julgamentos prévios e as conclusões prematuras.

"O pesquisador permanece em campo envolvido, durante um período durável, na vida cotidiana dos membros de uma comunidade ou grupo homogêneo, geograficamente determinados, partilhando de suas práticas, hábitos, rituais e concepções, sem pré-julgamentos ou preconceitos pessoais para compreender a cultura dos grupos. Este contato próximo habilita o pesquisador para alcançar um conhecimento íntimo e amplo do grupo, apreendendo não só o que ocorre no local, mas também como é visto, construído e usado pelos membros do grupo nas atividades habituais do dia-a-dia.

O pesquisador introduz-se no grupo, ocupando um lugar usualmente inexistente, ou "acultura-se" ao grupo, participando dele como um membro natural.” (2010:71-72)

A natureza do estudo etnográfico também aponta para a condução da pesquisa ao que é amplamente conhecido como estudo de caso. Por conta disso, uma unidade escolar foi selecionada para integrar o corpus da pesquisa. A ideia de realizar um microestudo, em um grupo bem delimitado e específico, decorre da necessidade de atuar nas ações pertinentes ao campo, por meio da atualização bastante restrita, de um recorte mínimo, que se analisa em detalhe.

Não obstante e ainda influenciado pelo já citado espírito de vigilância, que não se dissipa de maneira nenhuma com a definição da estrutura metodológica que 
nos parece mais conveniente, não deixamos de refletir a respeito das limitações próprias desta composição. Como lembra Haguette, escolher o caminho da observação implica em pelo menos dois fatores limitadores. Por um lado, não será possível fazer generalizações a partir dos resultados, uma vez que ela "busca mais os sentidos do que as aparências das ações humanas” e, por esta razão, acaba por estabelecer "seus próprios limites”. Além disso, existe sempre o risco de, dada a relação constituída entre observador e observados, ocorrer a "obliteração da percepção do primeiro em consequência do seu envolvimento na situação pesquisada”. (2000:76)

A respeito do primeiro aspecto, cabe única e exclusivamente apegar-se à constatação de que abrimos mão da possibilidade de generalização, nem tão comum nas pesquisas oriundas das ciências humanas, que, com frequência, são influenciadas pelos métodos quantitativos, para ganharmos em profundidade.

Reconhecemos esta deficiência e não só pela impossibilidade que se manifesta já no momento de elaboração do enunciado do problema. Isto porque a incapacidade de generalizar é constatada quando a pesquisa nasce.

Quanto ao segundo aspecto, e especialmente por se tratar de uma pesquisa que se realiza na escola, recorremos aos estudos realizados neste campo, obviamente também influenciados pelo estudo etnográfico. O objetivo era colher técnicas, métodos e modelos que ajudaram tais pesquisadores na construção de suas pesquisas, os limites e resultados alcançados. Os já citados trabalhos de Piovesan (1999) e Mendes (2006) não apenas são apoiados em estudos de observação, como também são feitos em salas de leitura, local onde ocorreu o principal levantamento da presente dissertação.

Além disso, resgatamos a obra Etnografia da Prática Escolar, elaborada por André (1995), que, além de retratar experiências que aliam tais pesquisas ao ensino formal, estabelece diferenças básicas entre o que poderíamos chamar de etnografia clássica - base da antropologia - e o que a autora denomina estudos etnográficos na educação. Enquanto a primeira se dedica exclusivamente à descrição cultural, qual seja, as práticas, hábitos, crenças, valores, linguagens, significados, etc., de um dado grupo social, os pesquisadores da educação estariam preocupados com o processo educativo. 
“Existe, pois, uma diferença de enfoque nessas duas áreas, o que faz com que certos requisitos da etnografia não sejam nem necessitem ser - cumpridos pelos investigadores das questões educacionais. Requisitos sugeridos por Wolcott (1988), como, por exemplo, uma longa permanência do pesquisador em campo, o contato com outras culturas e o uso de amplas categorias sociais na análise de dados. O que se tem feito, pois, é uma adaptação da etnografia à educação, o que me leva a concluir que fazemos estudos do tipo etnográfico e não etnografia no seu sentido estrito." $(1995: 28)$

Baseado nesta visão mais direcionada dos estudos etnográficos, que assumem caráter específico quando apropriados pelos pesquisadores da educação, sem deixar de considerar ainda as intercorrências comunicacionais, três técnicas foram utilizadas na operacionalização do presente trabalho: observação participante, pesquisa documental e o que chamaríamos de entrevista informal.

\subsection{Amostragem}

A população da pesquisa são o professor e alunos que frequentam salas de leitura das escolas municipais da prefeitura de São Paulo. De maneira mais específica, professor e estudantes do $9^{\circ}$ ano do ensino fundamental, que segundo dados da Secretaria Municipal de Educação alcançam 59.171 matrículas.

Cabe salientar que este é o último ano em que as aulas com essa finalidade e em local específico são oferecidas nas unidades municipais. Iniciadas ainda na educação infantil, mas sem regularidade, elas se transformam em encontro semanal a partir do primeiro ano do ensino fundamental e atravessam quase uma década do período de formação dos alunos. Cabe salientar que este é o último ano em que as aulas com essa finalidade e em local específico são oferecidas nas unidades municipais, já que, no Ensino Médio, os encontros não acontecem mais. 
Optamos pelos estudantes de $9^{\circ}$ ano como critério de amostragem partindo do pressuposto de que ao longo deste período eles tiveram pelo menos a oportunidade de entrar em contato com um número maior de livros e possivelmente possuem maior familiaridade com eles. O mesmo critério vale com relação ao contato e à experiência em relação aos meios de comunicação. Nesta idade os jovens têm mais acesso a aparelhos celulares, videogames e internet, além de mais autonomia em relação à escolha de um canal de TV, de uma estação de rádio, etc.

Pressupomos, portanto, que ao alcançarem tal estágio de formação, os educandos já tiveram a oportunidade de ler um número considerável de livros, inteiraram-se a respeito deles, participaram de um volume significativo de aulas em salas de leitura, conversaram a respeito de títulos e, por conta disso, puderam desenvolver a prática leitora.

Outro aspecto que merece destaque é o método de aula empregado nas salas de leitura. Ao contrário do que se verifica em outras disciplinas, que são formatadas dentro de um modelo mais rígido, com programa específico e conteúdo prédeterminado que tem necessariamente de ser transmitido, com avaliação e todos os ritos envolvidos no sistema padrão, nesses encontros os alunos são dotados de um grau de liberdade maior.

As salas dispõem de um acervo mínimo, com mesas espalhadas, onde as pessoas, muitas vezes, se organizam em grupo. A aula pode ser conduzida por uma temática específica ou os estudantes são simplesmente liberados para selecionar alguma obra, ler no próprio local e, caso se interessem, pegá-la emprestada para concluir a leitura em casa.

Algo que nos parece interessante neste desenho é a oportunidade de interação entre os alunos. Mais adiante serão exploradas as técnicas de coleta de dados e a observação (etnografia) foi uma das ferramentas selecionadas. Considerando a probabilidade de maior diálogo se mantidas as condições normais de aula, partiu-se da perspectiva de que durante estes "encontros" a interação entre os jovens e os meios de comunicação pode se manifestar na circulação do discurso. Dito de maneira mais clara, o que será verificado é se eles falam entre si a respeito de coisas que viram na internet, ouviram no rádio, assistiram na TV ou no cinema, 
se relatam experiências vivenciadas durante uma partida de videogame. Temáticas que, de alguma forma, podem influenciar no interesse por livros disponíveis na sala de leitura.

Além dos alunos, os professores das salas de leitura, também fazem parte da população da pesquisa. Sabe-se, por exemplo, que para ministrar tal aula o docente não precisa de uma formação específica. Independentemente do curso de ensino superior, seja de língua portuguesa, matemática, química ou história, desde que tenha licenciatura, ele já está apto para conduzir as aulas. A Secretaria Municipal de Educação oferece material próprio, além de cursos e capacitações específicos para as atividades em salas de leitura, mas esta preparação também não é pré-requisito para que o docente se torne responsável pela disciplina.

Uma unidade educacional localizada na região central da cidade foi selecionada para integrar a pesquisa. Trata-se da escola municipal de ensino fundamental Celso Leite Ribeiro Filho, localizada na Rua Humaitá, 480.

Ao todo, ela conta com 1.166 alunos matriculados, 16 salas de aula, uma sala de leitura, uma sala de informática e 84 educadores. Especificamente do $\mathbf{9}^{\boldsymbol{o}}$ ano, são três turmas, 87 alunos, com média de atendimento por turma de quase 30 estudantes, todos cursando no horário matutino e um professor de sala de leitura.

\subsection{Técnicas de pesquisa}

Das três técnicas de pesquisa utilizadas para o desenvolvimento da presente pesquisa, a observação é seguramente a mais importante. Ainda que tenha havido um criterioso levantamento da legislação municipal acerca das Salas de Leitura, que, inclusive, nos permitiu compreender qual é o tratamento (ou o não tratamento) dado aos media pelas sucessivas gestões, podemos dizer que esta forma de captação, que exige a apuração especialmente da capacidade auditiva e visual, foi determinante para a condução dos trabalhos e por duas razões principais, que não são necessariamente independentes. 
A primeira delas é o fato de que todo o trabalho teórico conduzido entre a escolha do tema, passando pela revisão bibliográfica, a definição do problema e objetivos de pesquisa parecem de alguma forma ter sinalizado para a utilização deste instrumento. A observação foi, sem dúvida, o principal recurso utilizado para levar a cabo a tentativa de atender às demandas deste projeto. Não é à toa, por conseguinte, que o que se verá ao longo das próximas páginas é uma dedicação maior tanto ao esforço de levantamento quanto da análise das informações geradas por intermédio deste recurso.

Em segundo lugar, pode-se afirmar que as demais técnicas utilizadas serviram como uma espécie de satélite, de apoio, de complemento, por um lado, ao conteúdo obtido por meio da observação, e, por outro, dos dados que ela simplesmente não seria capaz de gerar.

Para alguns autores, como Haguette (2000) e André (1995), a proposta de observação utilizada pode ser chamada de observação participante. Durante dois meses e meio, entre os dias 22 de março e 8 de junho de 2011, participamos de um total de 30 aulas em Sala de Leitura, de três turmas do $8^{\circ}$ ano, da Escola Municipal de Ensino Fundamental Celso Leite Ribeiro Filho.

Fomos apresentados a cada uma das turmas no primeiro encontro como um pesquisador, que participaria das aulas daquela semana em diante e que estaria ali para "observar o comportamento dos alunos, ouvir o que eles falam sobre as mídias e fazer algumas anotações”. 9

Apesar de não desempenhar nem o papel de aluno, nem de professor, “ocupando um lugar usualmente inexistente” (2010:72), com certa rapidez fomos absorvidos como integrante "aculturado" do grupo, "participando dele como um membro natural.” (2010:72). Não demorou para que os estudantes se dirigissem a nós, solicitando auxílio na seleção ou pesquisa de um livro, por exemplo, e até o próprio professor, em algumas ocasiões, pediu ajuda na montagem de equipamentos eletrônicos, como datashow, entre outros.

\footnotetext{
${ }^{9}$ Anotação no diário de bordo. A frase foi repetida da mesma maneira, para as três diferentes turmas por ocasião da apresentação. Evitei prestar maiores esclarecimentos do meu papel, limitando-me a cumprimentar os alunos e agradecer as manifestações de boas vindas.
} 
Voltaremos ao tema no capítulo que trata especificamente da descrição e análise dos tópicos observados pela pesquisa. A introdução prévia ao assunto teve o propósito de demonstrar que, na perspectiva das pesquisas que envolvem observação participante, a integração à sociedade existente, com seus hábitos e comportamentos próprios, deu-se com naturalidade e mesmo não pertencendo às classes e atores que normalmente fazem parte do cenário, já no terceiro encontro o observador estava incorporado.

Dadas as características da técnica, que, como afirma André, permitem “documentar o não-documentado” e descrever as vivências “da prática escolar”, uma vez que possibilita que sejam reveladas “as ações e representações dos seus atores sociais, reconstruir sua linguagem, suas formas de comunicação e os significados que são criados e recriados no cotidiano do fazer pedagógico” (1995:41), registramos tais percepções, conforme sugere Winks, com o auxílio de um diário. Ele foi utilizado a partir de suas funções essenciais, como forma de estruturar o estudo em questão. Ora apresentando a face "catártica”, ao fazer valer seu papel de "contratransferência”, de "lugar do corpo-a-corpo (...), ante o mundo social estudado” (1999:138). Ora valorizando aquilo que carrega de empírico, com as anotações de tudo que nos chamou a atenção durante as sessões de observação.

Se, por um lado, comparado a outras técnicas, como o questionário e a entrevista em profundidade, “a observação participante pode ser considerada como a técnica de captação de dados menos estruturada (...)”, já que "não supõe nenhum instrumento específico para direcionar a observação” (2000:77), não deixamos de realizar este trabalho a partir de uma olhar "sistematizável”. Ao recorrer mais uma vez a Wink, tomamos o cuidado de “desenhar topograficamente o lugar”, de maneira que nos fosse permitido "visualizar o mapa das flutuações em termos de uso, em tipos de público, mas também em sonoridade, em luz, em polifonia.” (1999:134)

A soma das justificativas, apoiadas em distintas referências bibliográficas, busca embasar também as outras duas técnicas utilizadas no desenvolvimento desta pesquisa. São eles: 
a) Entrevistas informais - durante ou ao final de algumas aulas, julgamos oportuno realizar algumas abordagens, quase sempre direcionadas ao professor da Sala de Leitura - mas não apenas a ele. Evitamos transformar estes diálogos em entrevistas formais por duas razões: (1), não queríamos perder a espontaneidade, nem a riqueza de informações permitidas por uma conversa ocorrida ainda sob a influência, in loco, no transcorrer e durante a ocorrência de determinado fato; e (2) entendemos que o eventual caráter formal de uma entrevista poderia direcionar as respostas às expectativas do entrevistador.

b) Levantamento documental - tal captação de informação se dá em dois sentidos: (1) por um lado, ao retomar a história das Salas de Leitura por intermédio das legislações existentes, sempre levando em consideração a inserção dos media neste contexto; (2) como suporte aos fatos observados durante as aulas. Por exemplo, se alguns alunos comentavam a respeito de um vídeo que viram no Youtube, uma pesquisa era realizada com o propósito de resgatar este material.

Cabe destacar que para contextualizar a Escola de Ensino Fundamental Celso Leite Ribeiro e sua respectiva Sala de Leitura foi utilizado também o recurso da fotografia. Não houve um rigor específico ou determinados parâmetros para os registros imagéticos, exceto a intenção de elucidar melhor o entorno e caracterizar certas particularidades.

Maiores esclarecimentos a respeito das especificidades próprias e da utilização de cada uma das técnicas citadas serão feitas no decorrer das descrições/análises que se seguem. Isto porque nos pareceu mais oportuno fornecer maiores detalhes no transcorrer dos diálogos, tendo em vista a possibilidade de melhor elucidação e da maneira devida. 


\section{LEVANTAMENTO E ANÁLISE DE DADOS}

\subsection{Resgate histórico do Programa Sala de Leitura - Critérios e caminhos}

Para refazer o percurso do projeto Sala de Leitura, tomamos como referência o conjunto de leis, decretos, portarias e demais documentos que pudessem de alguma forma esclarecer como se deu esta trajetória. Em realidade, mais do que o resgate histórico, o que pretendemos é identificar se os media foram de alguma forma admitidos neste ambiente escolar, em que momento e de que maneira. Em outras palavras, buscamos verificar se foram introduzidas políticas educacionais ao longo do desenvolvimento do programa, que tinha como princípio a admissão do rádio, da televisão, do videogame e mais recentemente do aparelho celular e da internet como participantes do processo de leitura. Em outras palavras, buscamos verificar se foram introduzidas políticas educacionais ao longo do desenvolvimento do programa que tivessem como princípio a admissão do rádio, da televisão, do videogame e mais recentemente do aparelho celular e da internet como participantes do processo de leitura. Teria sido implantada, por exemplo, alguma ação de estímulo à leitura destes meios e plataformas? Foram criadas condições para a circulação do discurso veiculado por tais aparatos de comunicação? Considerou-se a possibilidade de utilizá-los como caminho para aproximar os alunos dos livros?

Para atingir tal objetivo, fizemos uma análise desta legislação, que cobre o período entre 1973 e 2008, tendo como referência os seguintes critérios:

a) Observar quais os objetivos e as finalidades para a introdução do programa Sala de Leitura nos diferentes governos que se sucederam;

b) Como se deu e que recursos foram utilizados no desenvolvimento do programa Sala de Leitura; 
c) Quais as definições e abrangência do termo leitura nas diferentes gestões que administraram o programa Sala de Leitura;

d) Verificar se esta legislação faz alusão a outras formas de leitura, que estão além da referência impressa, do texto escrito;

e) Identificar possíveis menções, diretas ou indiretas, aos meios de comunicação como recurso para atividades de Salas de Leitura;

Identificar possíveis menções, diretas ou indiretas, aos meios de comunicação como fonte de possíveis leituras.

\subsection{As salas de leitura e os media: um percurso de idas e vindas}

O início do programa Salas de Leitura está relacionado a um projeto-piloto chamado Biblioteca-Escola, que foi introduzida pela então Secretaria de Educação e Cultura. Estabelecida por meio da Portaria 2.032, de 13 de julho de 1972, ela determinava que os alunos de ensino fundamental da Escola Municipal Maria Antonieta D’Alkimin Basto realizassem uma visita semanal à Biblioteca Infantil Anne Frank, com o objetivo de aprimorar e estimular o gosto pela leitura.

As atividades pedagógicas eram realizadas em conjunto e envolviam tanto o bibliotecário quanto o professor, que realizavam trabalhos paralelos aos especificados pelo programa oficial da rede municipal de ensino. A idéia era despertar o interesse pelos livros de literatura, tendo como princípio trabalhar questões como a compreensão de textos, assim como melhorar o desempenho dos estudantes em comunicação e expressão oral.

Três anos depois, o benefício foi estendido para outras 12 escolas e 11 mil crianças graças a três medidas legislativas complementares. Entre as ações nelas previstas estavam a efetivação do projeto, a destinação de verba específica para a compra de livros e de mobiliário para o atendimento de suas demandas, formação de um grupo responsável pela gestão, bem como o estabelecimento de um 
programa pedagógico unificado, que pudesse se estender a todas as unidades escolares e bibliotecas participantes. ${ }^{10}$

O gradativo aumento do número de escolas agregadas ao projeto também culminou com a implantação de quantidade cada vez maior de salas com tais finalidades no interior das próprias escolas. Dito de outra maneira, estas aulas eram transferidas de seu local original (as bibliotecas públicas) para serem incorporadas pelas próprias unidades escolares.

Ainda que algumas destas medidas representassem a reorganização administrativa da Secretaria ${ }^{11}$ e, por extensão, do próprio programa, elas também indicavam determinações claras em relação ao crescimento desejado. Em 1978, por exemplo, a ampliação de 45 para 86 salas de leitura foi formalizada. ${ }^{12}$

Cabe destacar, entretanto, que a estruturação destes ambientes quase sempre ficava sob responsabilidade da própria unidade. A instalação era autorizada se dispusessem de espaço físico sobressalente e tivessem recursos próprios para financiar eventuais reformas e a aquisição de acervo. Uma ou outra unidade fugia à regra e foi contemplada com verba e doação de livros.

No início dos anos 80, o prefeito Antonio Salim Curiati publicou um decreto que estabelecia o incremento de 300 novas Salas de Leitura às 130 já existentes. ${ }^{13}$ O que chama a atenção é que o mandatário não determinava nem prazos, nem como, nem por meio de que fontes de financiamento tão ousada ampliação seria feita. Muito pelo contrário, flexibilizava o cronograma de implantação (ou simplesmente não o considerava) ao anunciar, no artigo $4^{\circ}$, que ficaria sob responsabilidade do titular da pasta de Educação a fixação de "normas para instalação de Sala de Leitura e designação dos respectivos encargos, de forma gradativa, atendendo às necessidades da rede escolar e às disponibilidades orçamentárias da pasta”.

O caráter gradativo manifesto na legislação foi tamanho que, cinco anos depois, quando o prefeito Jânio Quadros concluía a sua administração, havia apenas

\footnotetext{
${ }^{10}$ Decreto 10.541 de 29 de junho de 1973, Portaria 1.330 de 16 de setembro de 1973 e Portaria 5.697 de 30 de dezembro de 1975.

11 Lei 8.694 de 31 de março de 1978.

12 Decreto 15.002 de 31 de março de 1978.

${ }^{13}$ Decreto 18.576 de 3 de fevereiro de 1983.
} 
263 salas de leitura. Diga-se de passagem, nenhum decreto, portaria, lei ou similar que tratava o tema foi publicado durante este período.

A administração Luiza Erundina foi a que mais elaborou decretos, portarias e leis que de alguma forma abordavam as Salas de Leitura. ${ }^{14}$ Durante a gestão, o projeto recebeu uma regulamentação efetiva. Ela se transformou em espaço oficial de todas as unidades escolares, a ser introduzido de acordo com as condições físicas locais e os recursos disponibilizados pela gestão. Também foi o primeiro momento em que se estabeleceu uma política de compra e distribuição de livros com esta finalidade. Além disso, o professor responsável pelo ambiente passou a receber treinamento específico para auxiliar na condução das aulas.

As bases originais do projeto, que valorizavam maior flexibilidade e ausência de um currículo programático e de avaliação, foram preservadas. Entretanto, é possível notar que, naquele momento, ocorreu uma distinção mais clara entre as atividades próprias de uma biblioteca e aquelas que passaram a caracterizar as salas de leitura. Diga-se de passagem, foi a primeira vez que surgiu uma definição e se estabeleceu o papel destes espaços. Por meio do levantamento realizado no arquivo técnico da Secretaria Municipal de Educação, identificamos um documento de 1991, denominado Política de leitura das escolas municipais de São Paulo, que traz esta textualização original:

"Seu objetivo é promover a mediação da leitura através da coordenação do professor encarregado da Sala de Leitura e dos demais educadores. É um espaço cultural para a leitura crítica do mundo onde o aluno se insere, localizando-o no tempo e no espaço e instrumentalizando-o para elaborar o conhecimento e transformando-o para transformar a sociedade e a ele mesmo."

\footnotetext{
${ }^{14}$ Lei 11.434 de 12 de novembro de 1993; Decretos 28.603 de 20 de março de 1990, 28.713 de 25 de maio de 1990, 28.889 de 25 de julho de 1990 e 32.582 de 10 de novembro de 1992; Portarias 3.128 de 29 de maio de 1990, 4.007 de 10 de maio de 1990, 4.580 de 16 de agosto de 1990 e 12.780 de 8 de dezembro de 1992.
} 
Constata-se pelo registro que esta gestão foi a primeira também a admitir a atividade leitora como transcendente à relação que se constitui entre o leitor e o livro impresso, o texto escrito, registro em papel. A leitura do mundo é a leitura da realidade que nos cerca, das experiências vividas e, entre elas, nossas experimentações com os meios de comunicação.

O estabelecimento de um plano de capacitação continuada, a integração de suas atividades com o planejamento da escola e a definição das atribuições do professor responsável por estas aulas, particularmente registrados nas Portarias 3.128 e 4.580 de 1990, reforçam estas perspectivas. Torna-se finalidade das Salas de Leitura, a partir desta normatização, o desenvolvimento de "atividades culturais como: festivais de poesia e música, documentação da história do bairro, construção de jornais, álbuns de foto da região, etc.”

Não poderíamos deixar de destacar ainda um dispositivo presente na Portaria 12.780 de 1992, que representou uma das principais dissociações do papel do professor orientador de Sala de Leitura em relação a um bibliotecário. Até então, o primeiro era obrigado a promover a catalogação do acervo com base nos procedimentos adotados pelo último. Além disso, servia de orientador à realização de pesquisas bibliográficas tanto de alunos quanto dos demais professores da unidade escolar.

A partir da Portaria, a organização do material disponível se tornou mais flexível e as atribuições típicas do profissional de biblioteconomia foram retiradas do professor. A intenção não estava explícita no documento, mas arriscamos afirmar que tal medida tinha como propósito tornar as Salas de Leitura um ambiente menos formal, talvez mais lúdico, mais acessível, menos burocrático.

Achamos conveniente mencionar o fato porque, no ano seguinte, no primeiro semestre do mandato de Paulo Maluf, ela foi revogada pela Portaria 5.168 de 17 de junho de 1993. Nela, o então secretário de Educação, Mário Sergio Cortella, resgataria as funções anteriores do professor coordenador da Sala de 
Leitura, em um gesto que marcaria o conjunto de ações burocráticas dos quatro anos seguintes. $^{15}$

As providências tomadas se voltaram à criação de um grupo executivo, que tinha a finalidade de qualificar as equipes docentes, realizar palestras e solucionar pendências gerais. Além disso, reviam critérios de organização e horário e restringiam a possibilidade de se candidatar ao cargo de coordenador de Sala de Leitura apenas aos professores titulares da rede pública municipal, o que limitou consideravelmente o número de docentes aptos a disputar as vagas disponíveis, assim como obrigou uma quantidade significativa daqueles que já estavam no exercício das funções a deixá-las.

Por outro lado, se na gestão de Erundina podemos notar a ampliação do entendimento em relação ao papel da Sala de Leitura, pela primeira vez, no decorrer de toda a legislação publicada e que de alguma forma abordava o assunto, na gestão de Maluf o ato de ler passou a ser entendido como uma forma de satisfação e prazer. Já nas considerações iniciais do Decreto 35.072 de 1995, o texto menciona a importância de "garantir aos escolares o acesso às diferentes fontes de leitura e diversas formas de linguagem, e assim, favorecer o prazer de ler e a ampliação de conhecimentos”.

Embora a frase seja passível de múltiplas interpretações, é possível que as "diferentes fontes" e as "formas de linguagem" considerassem os meios de comunicação. Em todo caso, no levantamento realizado não foi possível identificar qualquer treinamento ou aquisição para o acervo que fizesse alguma alusão neste sentido. Mas a simples menção e a possibilidade de interpretação podem ser vistas como avanços se considerarmos o fato de que nada similar foi textualmente registrado nos decretos, portarias e leis anteriores.

Entre 1997 e 2000, período em que Celso Pitta foi Prefeito do município de São Paulo, encontramos três publicações que mencionam as Salas de Leitura. ${ }^{16}$

\footnotetext{
15 Além da já citada, as Portarias 8.351 de 17 de dezembro de 1993, 3.107 de 25 de maio de 1995 e 5.264 de 6 de novembro de 1996 e o Decreto 35.072 de 20 de abril de 1995.

16 Decreto 36.969 de 30 de julho de 1997, Portaria 4.810 de 8 de agosto de 1997 e Portaria 7.851 de 30 de dezembro de 1997.
} 
A primeira instituiu as Salas de Leitura também nas escolas municipais de ensino infantil. A segunda regularizava as práticas deste novo espaço e, ao contrário do que se observava nas unidades de ensino fundamental, a determinação era de que não houvesse um professor específico para estas aulas. Portanto, sob a orientação do coordenador pedagógico, os próprios docentes que promoviam outras atividades com os alunos teriam tais responsabilidades.

A terceira, uma portaria que regularizava o já citado Decreto 35.072, reiterava o sentido proposto de ampliação do conceito de leitura. Dentre os objetivos destacados no artigo $1^{\circ}$ da Portaria 7.851 de 1997 , o texto resgatou a ideia de “acesso às diferentes fontes de leitura e diversas formas de linguagem”, mas acrescenta o verbo oferecer como indicação clara de que é papel do poder público, em especial da Secretaria Municipal de Educação, por intermédio das Salas de Leitura, disponibilizar para os estudantes diferentes plataformas de leitura.

Durante toda a gestão da prefeita Marta Suplicy apenas um Decreto, publicado a três dias do término de seu mandato, o 45.654 de 27 de dezembro de 2004, abordou a questão. Ele dispõe a respeito da criação e organização da Sala de Leitura e no artigo $3^{\circ}$ faz menção mais específica às “atividades diversificadas” às quais elas devem se prestar, "envolvendo as múltiplas linguagens e favorecendo a memória das tradições e a geração da cultura”.

Nos dois artigos seguintes, o papel e a condição de espaço de convívio, também chamado de Espaço de Leitura, foram mais bem esclarecidos e, ao contrário da abordagem implícita verificada nas três administrações anteriores, o reconhecimento de outras leituras possíveis, inclusive de referências midiáticas, se tornou explícito. :

Art. $4^{\circ}$. O Espaço de Leitura é o recanto onde se aloca o conjunto de compêndios, livros, revistas, jornais e outros da espécie, disponibilizando referidos materiais para atendimento dos educandos em sala de aula, possibilitandolhes oportunidades de apropriação de informações com atividades diversificadas, envolvendo as múltiplas linguagens e favorecendo a memória das tradições e a geração da cultura. 
Art. $5^{\circ}$. As Salas de Leitura e os Espaços de Leitura terão sua atuação articulada e em consonância com os princípios educacionais do Laboratório de Informática Educativa, Sala de Vídeo, Laboratório Radiofônico (EDUCOM), Projeto Recreio nas Férias, Projeto Escola Aberta e demais recursos existentes, todos integrantes do Projeto Político Pedagógico das unidades educacionais.”

Neste contexto, as Salas de Leitura definitivamente seriam um espaço para as leituras. Reconhecendo a existência de outras formas, que transcendem o livro, a palavra impressa, o registro em preto na folha branca, considerava este processo como integrado, entre as vivências individuais e coletivas, que se faz de maneira conjunta.

Pouco mais de sete meses depois, quando José Serra já estava à frente da administração da capital paulista, um novo decreto, o 46.213 de 15 de agosto de 2005, anulou as prerrogativas midiáticas definidas pela gestão anterior. Curiosamente, o texto promoveu alterações específicas e justamente nos pontos que citavam a diversificação das atividades, as diferentes linguagens e que faziam menção à integração entre esse espaço e outros programas, que envolviam as aulas de informática, vídeo e rádio, entre outros. Com as alterações nos artigos, fica bem clara a intenção de recuperar uma primeira concepção da Sala de Leitura, que considerava o espaço como lugar de envolvimento com o texto impresso e com as obras literárias: “As Salas de Leitura são espaços onde os alunos devem aprender comportamentos de leitor, por meio de atividades de leitura de diversos gêneros textuais em suas diferentes funções.”

Inclusive, a Portaria 104 de 7 de janeiro de 2006, que regulamentou o Decreto, reiterava a pragmática ao mencionar que estes espaços "visam precipuamente à inserção dos alunos na cultura escrita”. E dentre seus objetivos específicos estabelecia que as Salas de Leitura deveriam “favorecer a aprendizagem dos diferentes procedimentos de leitura e uso dos diversos gêneros de circulação social”. 
O Decreto 49.731 de 10 de julho de 2008 e a Portaria 3.078 de 24 de julho de 2008, publicados já durante a administração Gilberto Kassab, apenas ratificavam tais premissas, sem ampliá-las, limitá-las ou alterá-las.

O que parece se evidenciar a partir da análise do conjunto de leis, decretos e portarias elaborados pelos sucessivos governos, desde o início do programa Salas de Leitura, originalmente conhecido como Biblioteca-Escola, é uma trajetória irregular. Se por um lado, entre os governos Erundina e Marta Suplicy, verifica-se a acentuada ampliação da ideia de leitura, com a introdução de ações que levam em consideração outras práticas culturais, outras linguagens e a influência das mídias, as gestões seguintes Serra e Kassab representam um retrocesso, do ponto de vista da incorporação de outras e novas formas de compreensão do mundo.

Aliás, ao recuperar tal percurso, observamos que nunca, até as últimas duas administrações, o papel da Sala de Leitura foi tão específico, tão voltado ao desenvolvimento de um “comportamento de leitor” nos estudantes. Tomando de empréstimo um dos termos presentes em uma das portarias, trata-se de um modelo que tem por objetivo precipuamente o desenvolvimento de atividades que explorem os “diversos gêneros textuais”.

Neste sentido, entendemos ser possível afirmar que, do ponto de vista da gestão, da proposta pedagógica, das políticas públicas, especialmente determinadas em leis, há pouco espaço para a circulação dos discursos presentes nos diversos meios de comunicação. Mais do isso, mesmo que este discurso esteja presente nas aulas em Sala de Leitura, não há um estímulo à sua utilização como forma de ampliação e colaboração com a prática leitora. A visão oficial, manifesta por intermédio da legislação, dá conta de um projeto que não considera os media ou, no limite, minimiza seu potencial revelador, seu papel na sociedade e na cultura contemporânea.

\subsection{Escola Municipal Celso Leite Ribeiro Filho - Olhar de Fora}


Mantida a ideia de que o estudo etnográfico se realiza em pequenos grupos, devidamente delimitados, a partir de um recorte específico, sem perder de vista as características socioculturais que permeiam estas micro-organizações, a opção foi por dar continuidade a este processo de determinação delimitação da população a ser estudada, com a descrição do tempo, do local e do entorno que representam e caracterizam a Sala de Leitura da Escola Municipal Celso Leite Ribeiro Filho. Assim, depois de um início em que o projeto foi tratado de maneira ampla, passamos pela desconstrução da unidade escolar, em seguida do local onde se realizam as aulas, para finalmente atingir os grupos nos quais a presente pesquisa é aplicada.

Dois instrumentos foram utilizados para compor esta fase do trabalho. A pesquisa documental, que foi realizada a partir da consulta a fontes oficiais de informação, como os portais na internet da Prefeitura do Município de São Paulo e da Secretaria Municipal de Educação. E a pesquisa fotográfica, constituída por um conjunto de fotos que retrata especialmente as ruas e os imóveis que cercam a escola e também o interior da instituição.

A Celso Leite Ribeiro Filho, localizada no bairro da Bela Vista, e a Escola Municipal Duque de Caxias, situada no Bairro da Sé, constituem as duas únicas unidades de ensino fundamental localizadas no centro da cidade. Para efeito de comparação, o portal da Secretaria Municipal de Educação ${ }^{17}$ indica que existem em todo o município 492 escolas que oferecem ensino do primeiro ao nono ano.

Segundo o censo ${ }^{18}$ de 2010, São Paulo conta com uma população de 11,2 milhões de habitantes. A Bela Vista, que faz parte da zona central, integra um conjunto de oito distritos municipais no qual estão também inseridos o Bom Retiro, o Cambuci, a Consolação, a Liberdade, a República, a Santa Cecília e a Sé. Soma no perímetro de sua unidade territorial 69,5 mil pessoas $(0,6 \%$ do total da

\footnotetext{
${ }^{17}$ A pesquisa foi realizada por intermédio do endereço http://portalsme.prefeitura.sp.gov.br/AnonimoSistema/BuscaEscola.aspx?source=/AnonimoSistema/ BuscaEscola.aspx em 17 de junho de 2011.

${ }^{18}$ Informações extraídas do endereço http://infocidade.prefeitura.sp.gov.br/htmls/7_populacao_recenseada_e_taxas_de_crescime_1980_7 02.html
} 
população de São Paulo) e destas apenas 8,9 mil ${ }^{19}$ têm idade para cursar regularmente o ensino fundamental (entre 6 e 14 anos).

Os dados indicam que a comunidade local representa um aglomerado pequeno se comparado com os de outras regiões. Os adultos são a grande maioria, com uma acentuada quantidade de solteiros $^{20}$ e um volume considerável de habitantes morando em situação precária e domicílios coletivos (1,8 mil famílias). ${ }^{21}$

O observador que caminha pelas ruas que compõem o seu entorno não apenas se depara com cortiços, prédios antigos, edificações abandonadas e casas deterioradas. Como revela o mosaico de fotos apresentado abaixo, ele também vai encontrar moradores de rua, lixo e sujeira, além de depredações.

\footnotetext{
${ }^{19}$ Informações extraídas do endereço http://infocidade.prefeitura.sp.gov.br/htmls/7_projecao_populacional_por_faixa_etaria_2010_565 . html

20 Informações extraídas do endereço http://infocidade.prefeitura.sp.gov.br/htmls/9_domicilios_segundo_numero_de_moradores_2000_45 $\underline{\text { 9.html }}$

${ }^{21}$ Informações extraídas do endereço http://infocidade.prefeitura.sp.gov.br/htmls/9_domicilios_segundo_tipo_de_ocupacao_2000_454.ht $\underline{\mathrm{ml}}$
} 


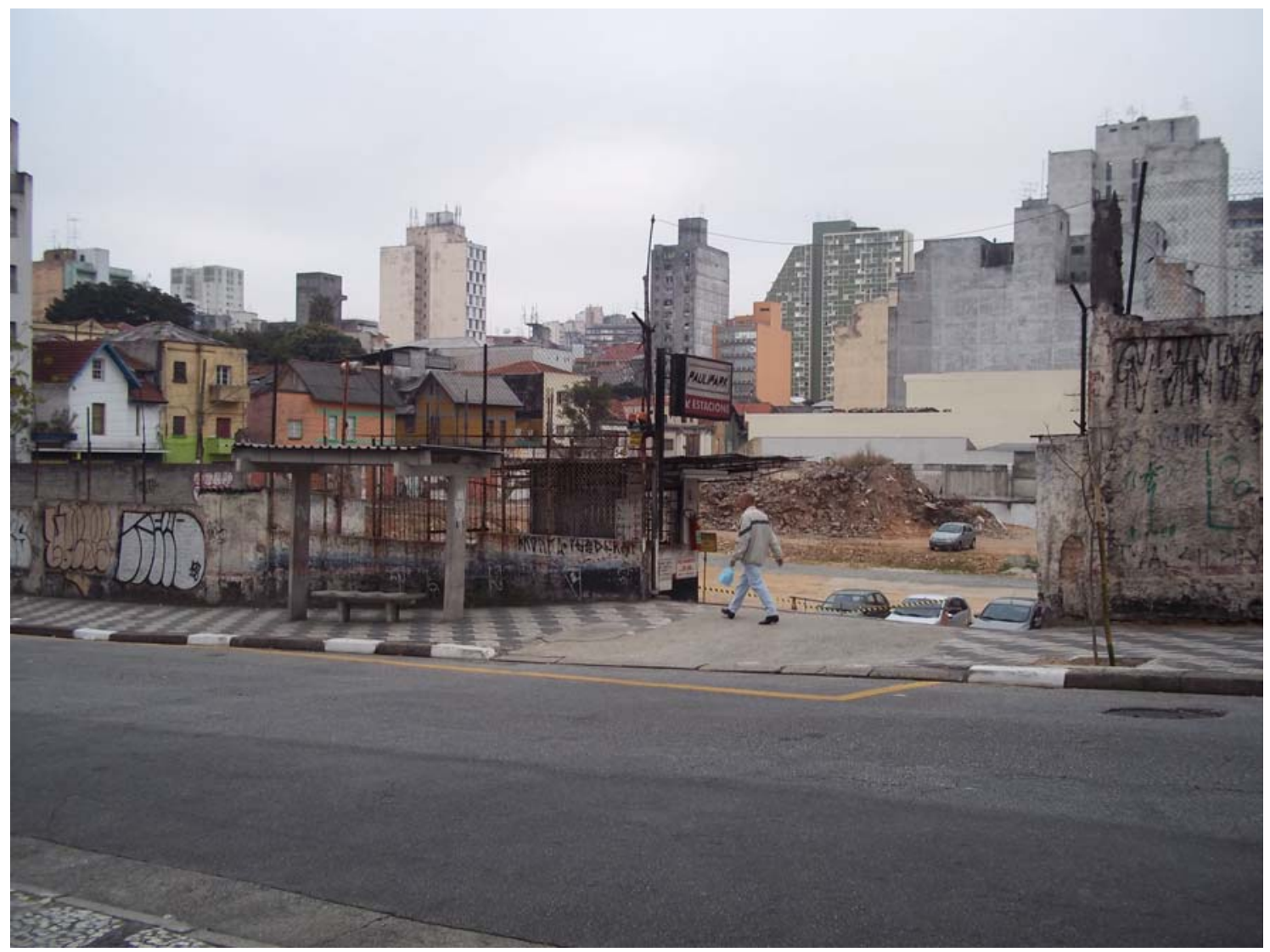

Figura 1 - Estacionamento improvisado em temeno abandonado há 20 anos 


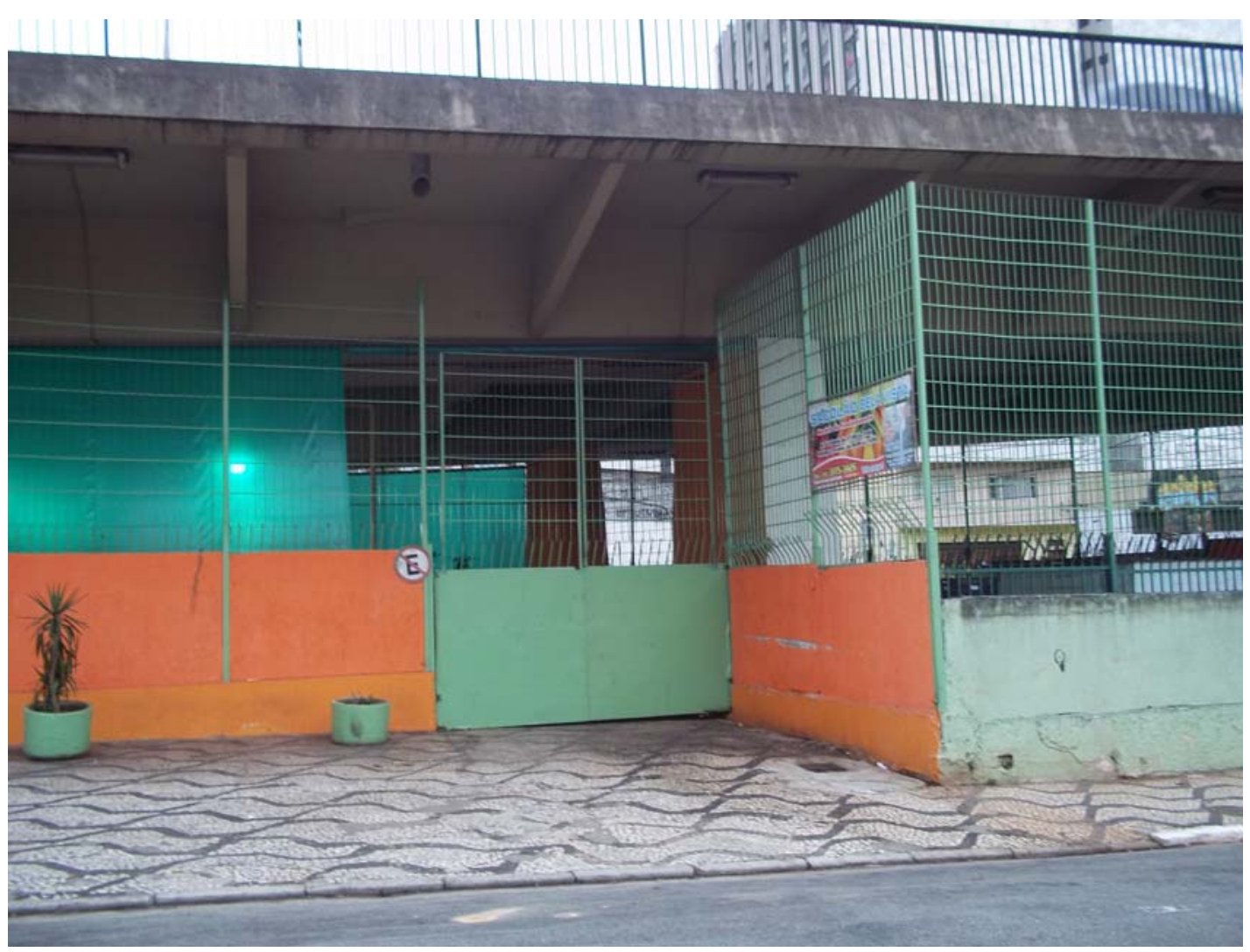

Figura 2 - Sacolão embaixo de viaduto visa minimizar ação de traficantes e moradias improvisadas 


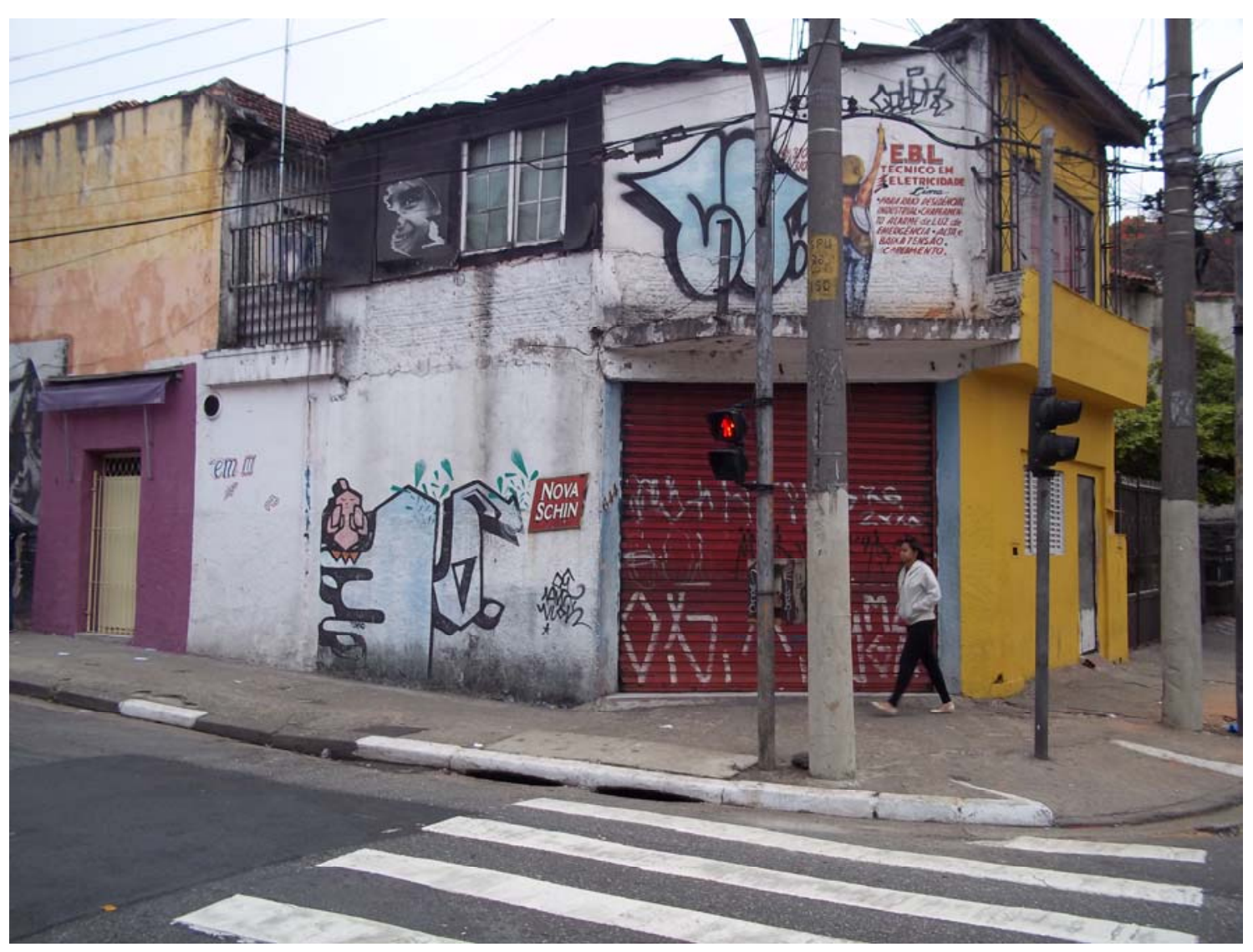

Figura 3 - Prédios comerc iais desoc upados a três metros da escola são alvo de pichadores 


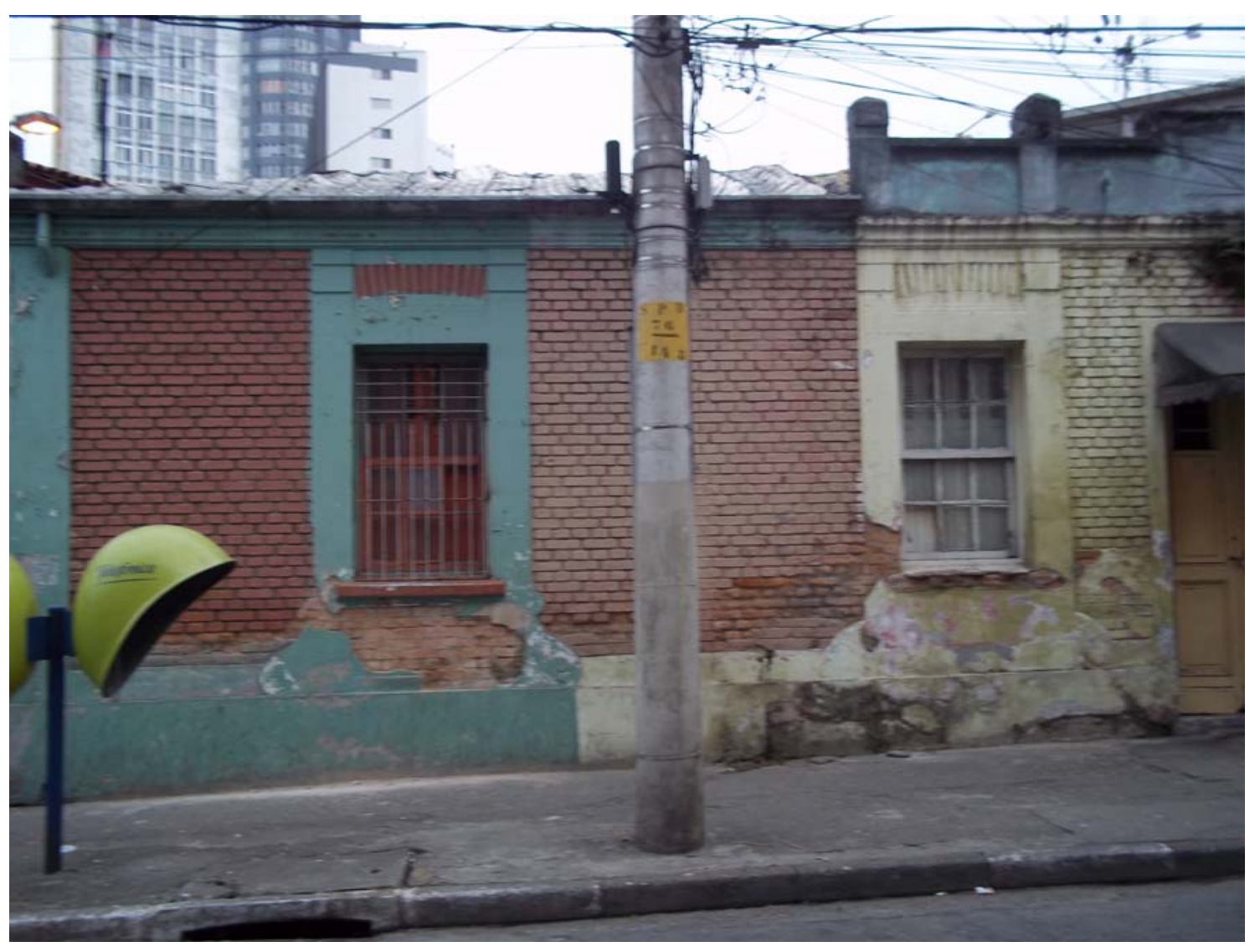

Figura 4 - Na quadra em que a unidade escolar está localizada há, pelo menos, oito cortiços 


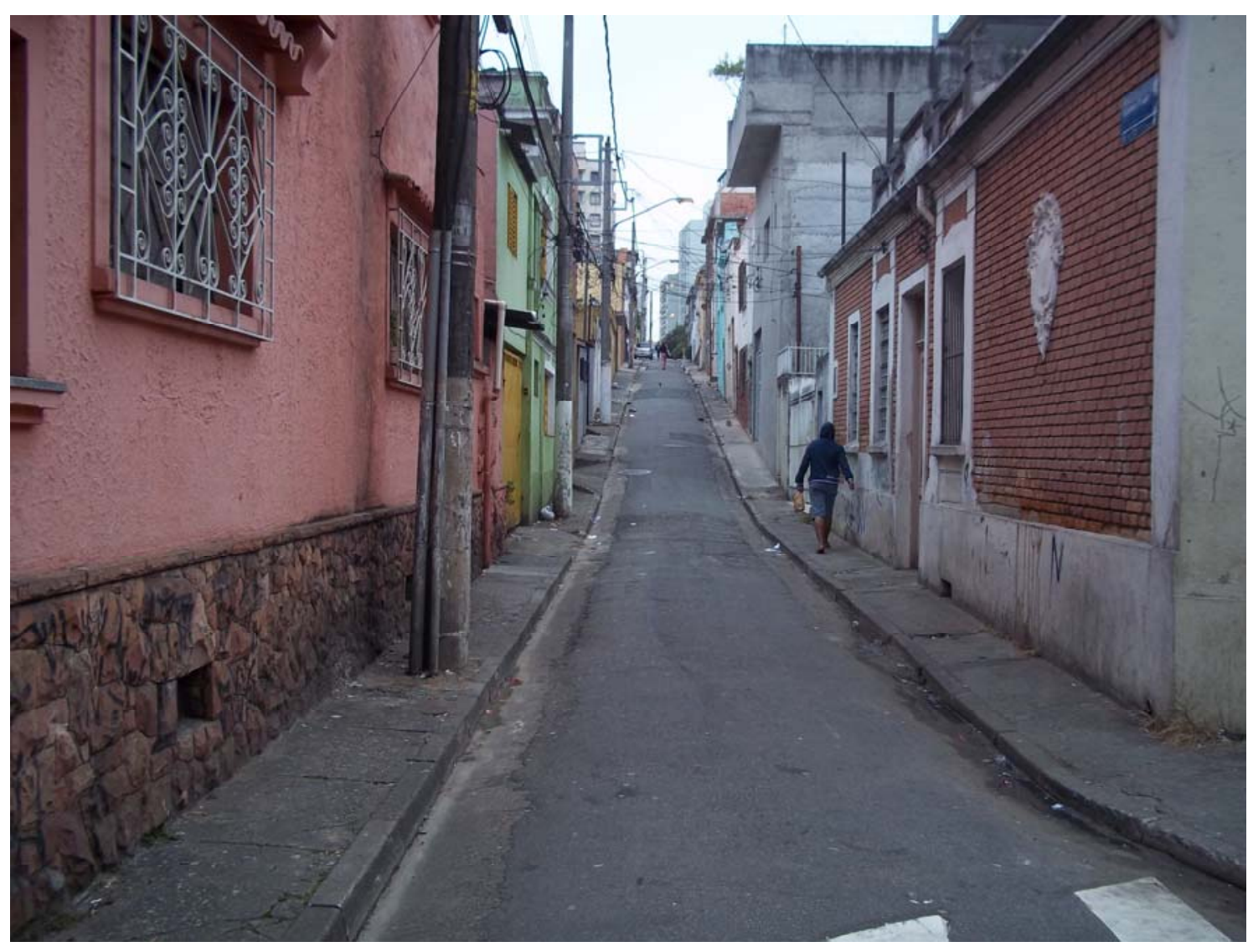

Figura 5 - Conjunto de casas localizado a menos de quinhentos metros da Celso Leite Ribeiro Filho 


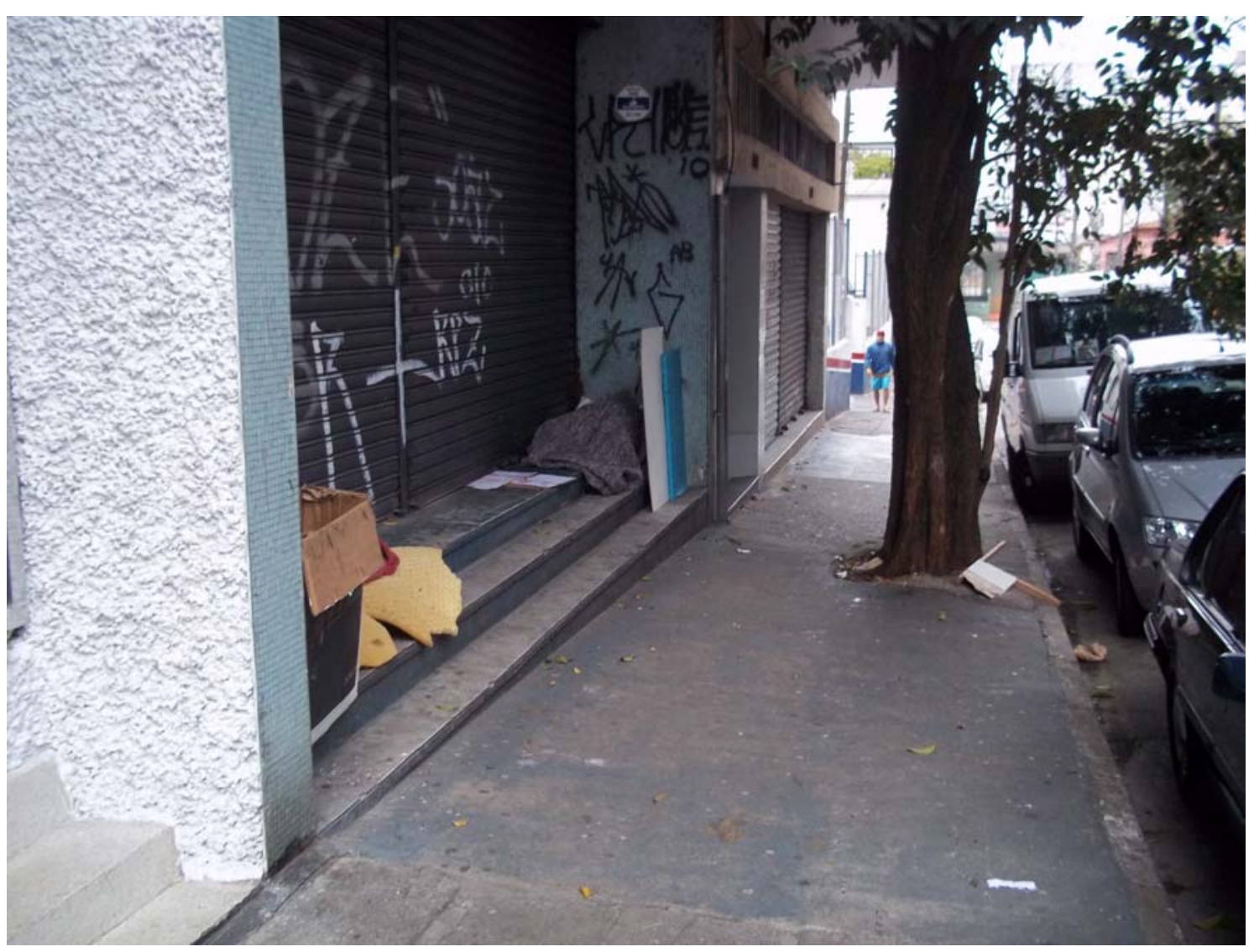

Figura 6 - Em uma manhã, antes do início das aulas, contamos 12 moradores de nua no entomo 


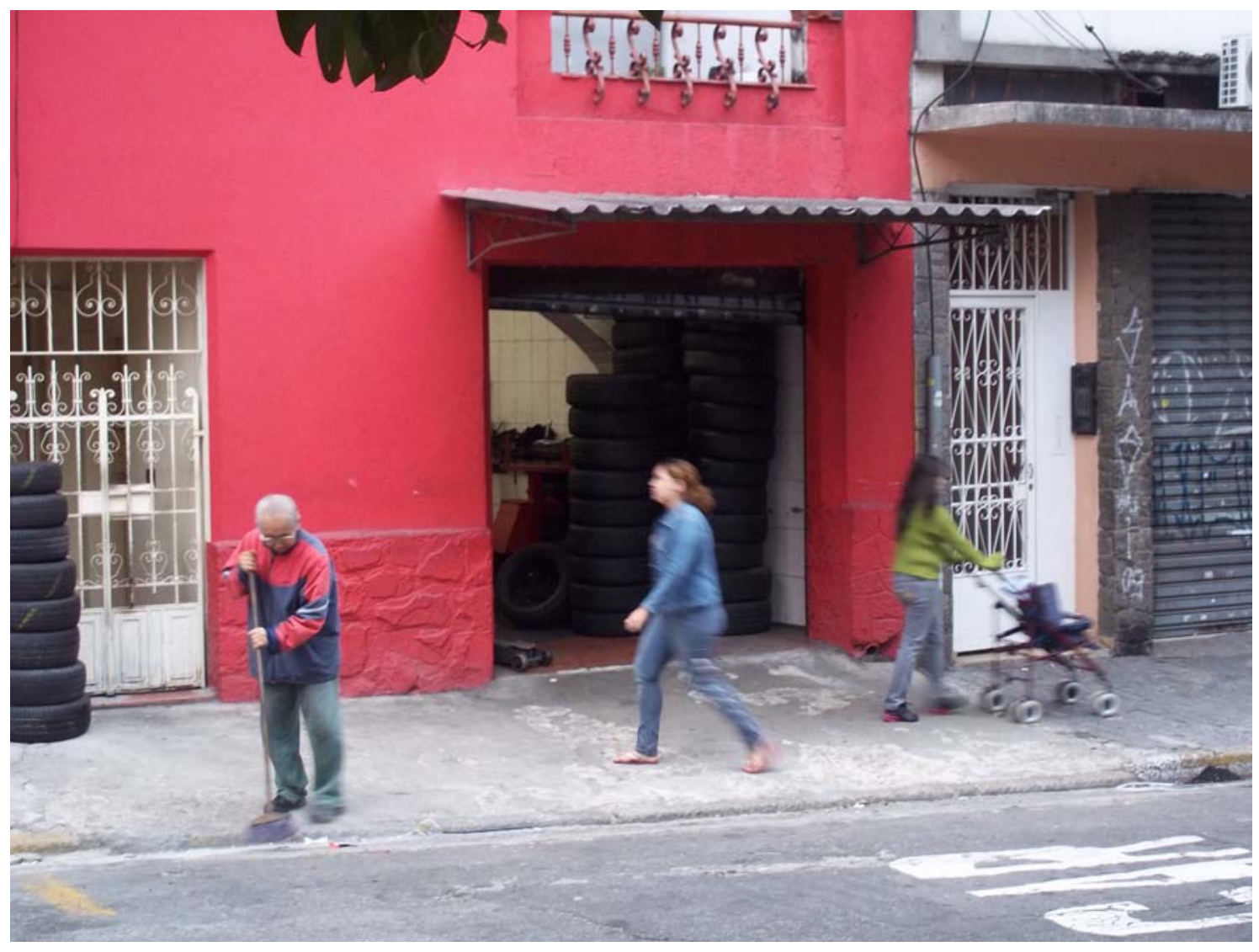

Figura 7 - Borrac haria, gráfica, costureira e empresa de segurança estão a cerca de cem metros da esc ola 


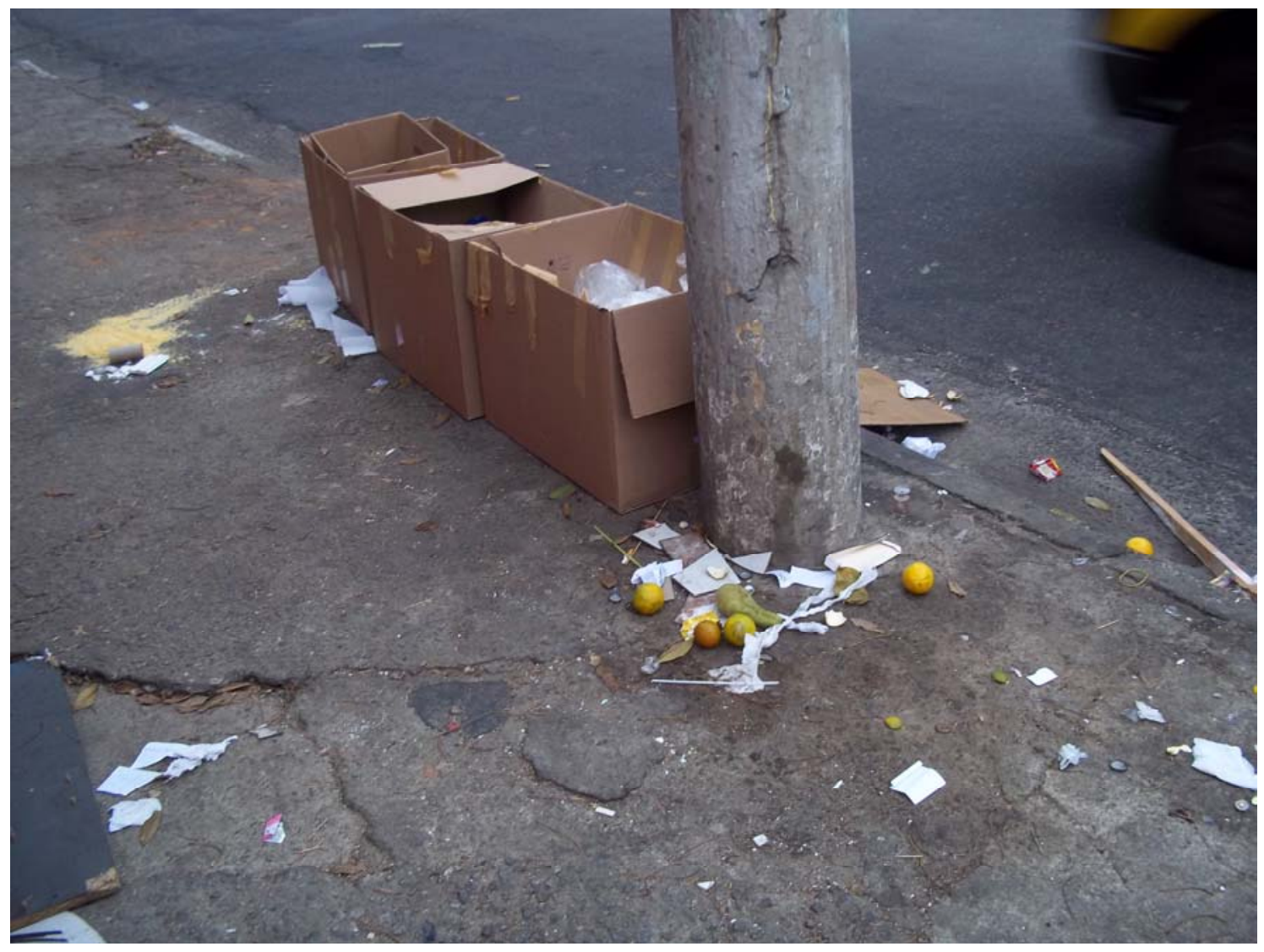

Figura 8 - Há lixo por toda parte, todos os dias, especialmente orgânico, como alimentos

A região é bastante carente em equipamentos culturais e esportivos, além de não contar com outros espaços de convivência e socialização. Não há parques nas proximidades e o bairro não dispõe sequer de uma biblioteca ${ }^{22}$. Vale destacar que a unidade mais próxima está localizada no Centro Cultural São Paulo, a cinco quilômetros de distância da escola. Além disso, à exceção da sala de informática que integra a EMEF e conta com 35 máquinas, existe apenas um Telecentro ${ }^{23}$, localizado na Rua Treze de Maio, em um raio de cinco quilômetros, com computadores e internet de acesso público.

\footnotetext{
22 Informações extraídas do endereço http://infocidade.prefeitura.sp.gov.br/htmls/6_disponibilidade_de_bibliotecas_publicas_2008_193. $\underline{\mathrm{html}}$

${ }^{23}$ Informações extraídas do endereço http://infocidade.prefeitura.sp.gov.br/htmls/6_telecentros_2009_528.html
} 
Nesta perspectiva, torna-se evidente que, de forma geral, a interação cultural e social dos alunos se dá (ou pode se dar) basicamente no ambiente educacional. É lá que ocorrem os debates, os diálogos e as manifestações possíveis por intermédio da leitura, do contato com os media, da dança, do teatro, das artes plásticas, das visitas programadas, das excursões, das práticas esportivas proporcionadas pela escola.

As ruas irregulares, acidentadas e íngremes, por onde circulam carros em alta velocidade; as ruas estreitas, sem iluminação adequada, sujas e desertas; as ruas das lacunas de teatro, cinema, parques e afins também não são espaços que favorecem a interatividade, o encontro coletivo. Fora da escola, ao que parece, os estudantes, não raro, só dispõem do refúgio do lar. É em casa que eles se reintegram ao mundo, por meio de seus aparelhos de rádio, de TV, seus celulares, seus computadores. Mas também é possível que nem ali haja essa imaginada, essa suposta e esperada relação com o outro e com eles mesmos. As condições precárias de moradia, os muitos habitantes de um mesmo cômodo, o banheiro que é de todos. Um mundo e um tempo que favorecem a solidão, reduzem algumas das características sociais próprias do ser humano e conduzem a uma consequente redução da capacidade e do potencial leitor.

\subsection{Olhar de dentro}

A Escola Municipal Celso Leite Ribeiro Filho fica ao lado de outros três equipamentos públicos: o Centro de Educação Infantil (CEI) Bela Vista, a EMEI (Escola Municipal de Educação Infantil) Ângelo Martino e o Centro de Especialização Odontológica Professor Alfredo Reis Viegas. Por esta razão, durante alguns períodos do dia, por exemplo, nos horários de entrada e de saída da aula, uma pequena multidão heterogênica, formada por pequenos e jovens estudantes, pais e responsáveis, servidores públicos de jaleco e pacientes, misturase em frente aos quatro portões coloridos que formam os conjuntos arquitetônicos.

Há um corredor e dois portões que separam a unidade escolar da rua. Essa espécie de antecâmara ao ar livre é larga, com aproximadamente dez metros de 
fachada. Para facilitar o trânsito de estudantes nos momentos de pico, a entrada principal conta com um sistema mecânico, que permite a suspensão da estrutura de metal. Já no interior da edificação, há uma quadra e um pátio, ambos descobertos, além de um corredor de acesso às áreas administrativas e às salas de aula.

Como é possível notar pelas fotos, há grades, portões e portas (algumas elétricas) por todos os lados, que acabam por transmitir a sensação de que se está entrando em uma unidade prisional. Ou, pelo menos, que existem limites e espaços aos quais os alunos têm evidente acesso restrito.

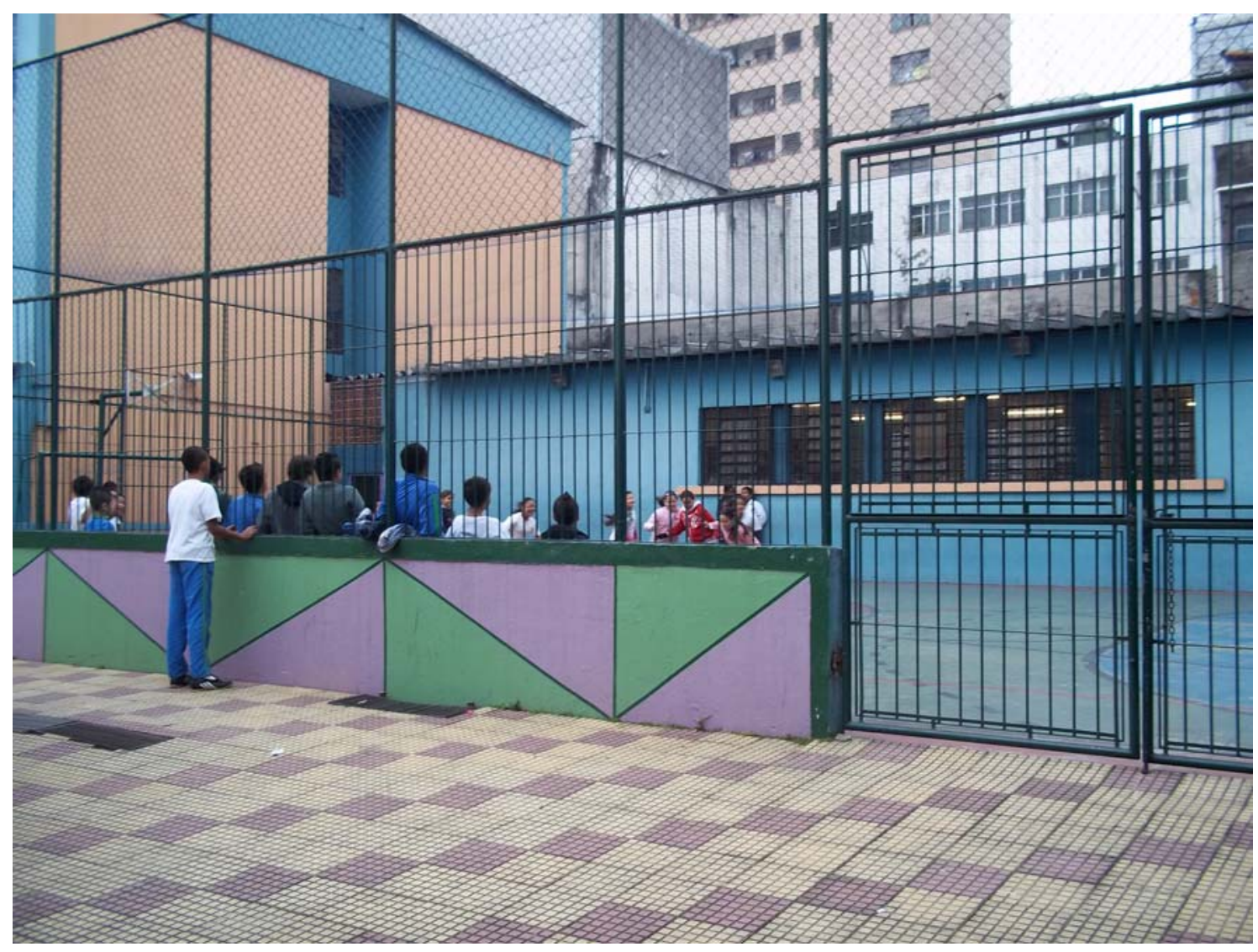

Figura 9 - Quadra cercada porgrades e ao fundo a sala de leitura 


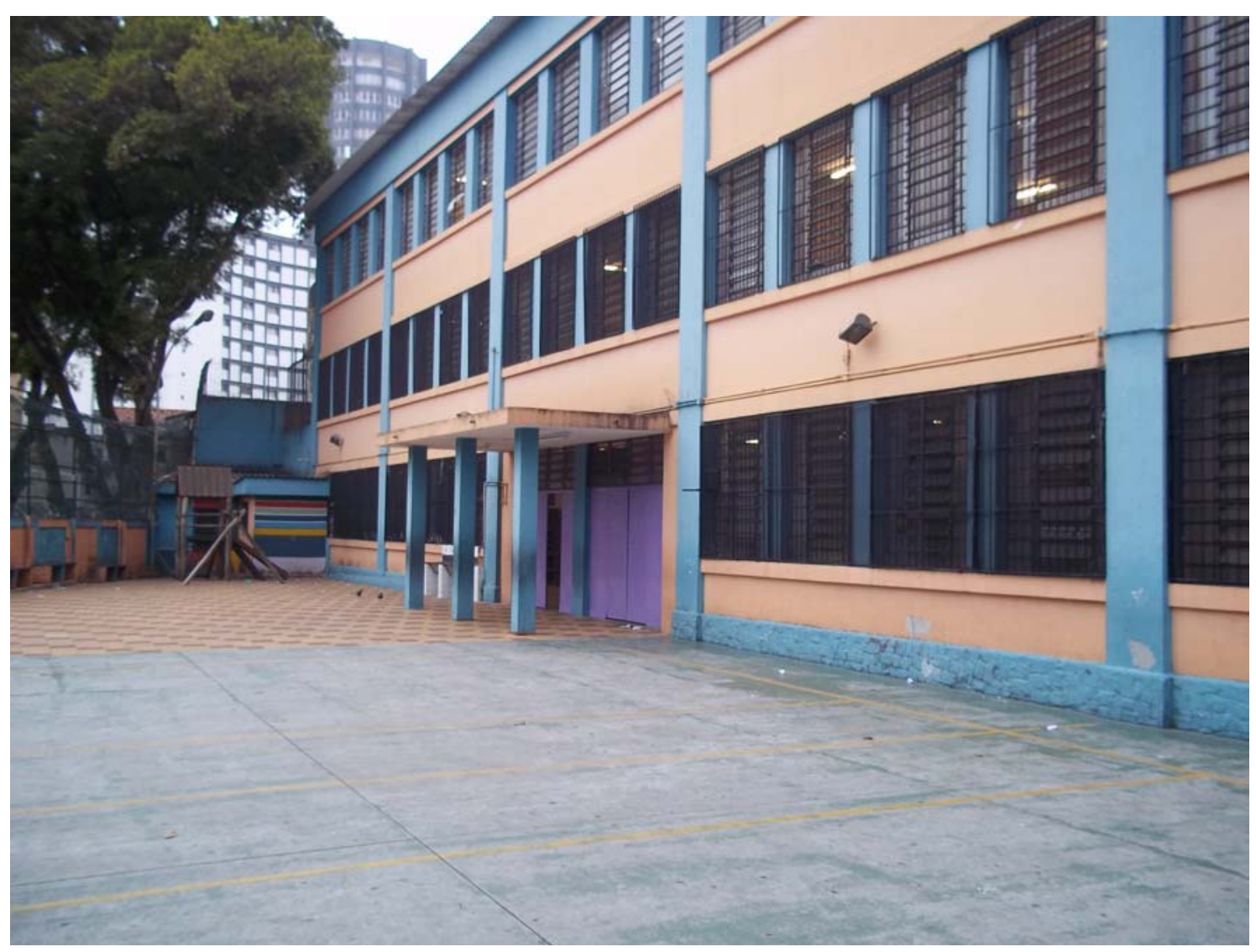

Figura 10 - Pátio extemo. No intervalo, o acesso é restrito a essa área, separada por grade da quadra 


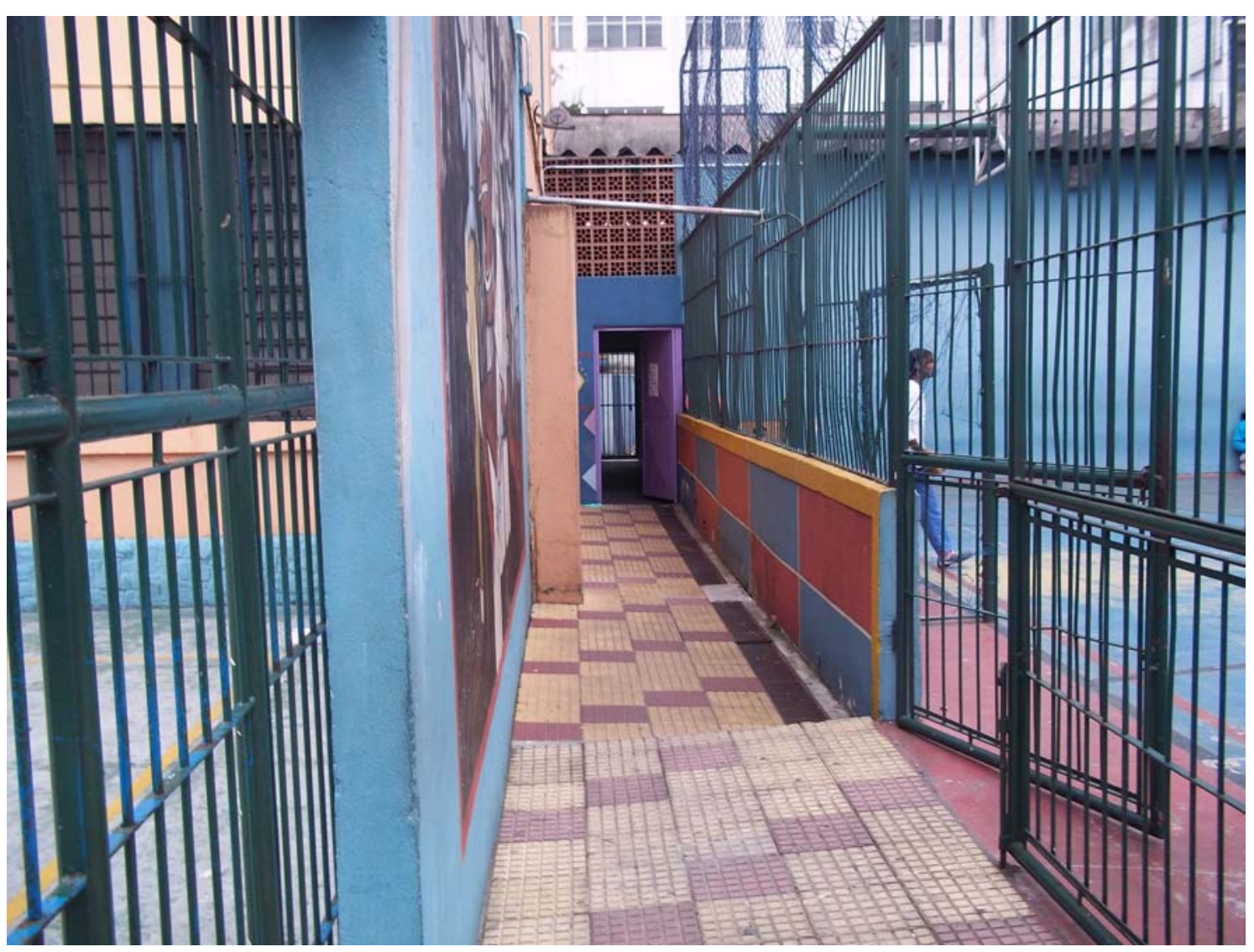

Figura 11 Comedor de acesso ao interior da escola: quadra à direita e pátio à esquerda

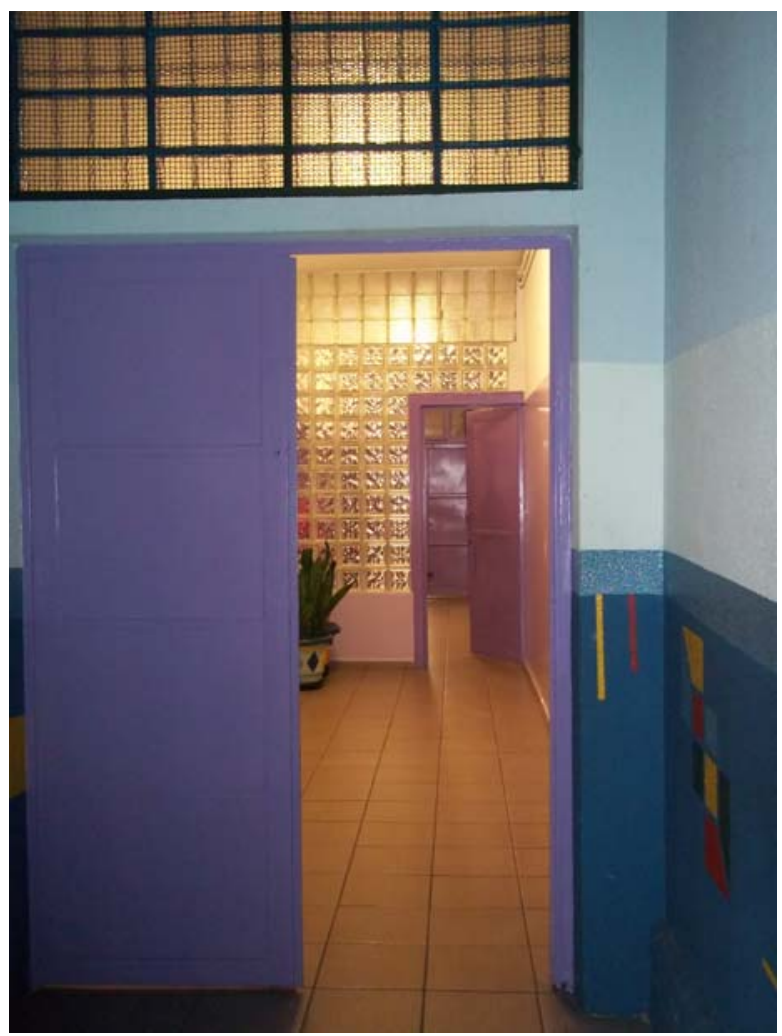




\section{Figura 12 - Três portas separam a recepção das salas de aula}

As 16 salas de aula da EMEF Celso Leite Ribeiro Filho fazem parte de um prédio único, de dois andares, com oito salas cada. ${ }^{24}$ Ao todo, 1166 alunos estão matriculados e 84 educadores fazem parte do corpo docente da instituição. São oferecidas aulas de ensino fundamental de primeiro a nono ano, além de educação de jovens e adultos de quinto a nono ano.

Além dos ambientes convencionais para a prática pedagógica e a já citada quadra externa, a escola conta ainda com um banheiro para deficientes (apesar de não possuir rampa de acesso aos andares superiores), uma sala de informática e uma sala de leitura.

Convém destacar ainda que a unidade escolar oferece 105 vagas para alunos do nono ano, divididas em três turmas, todas no período da manhã. Das vagas disponíveis, 87 foram preenchidas em 2011. Portanto, o universo desta pesquisa é constituído destes quase 90 alunos, organizados em grupos de cerca de 30, que semanalmente acompanham uma aula de 45 minutos. Tais encontros na Sala de Leitura acontecem às terças-feiras, para as turmas B e C, respectivamente nos horários das 7h55 às 8h40 e 8h40 às 9h25, e às quartas-feiras para a turma A, cujo horário é entre 7h10 e 7h55.

\subsubsection{A Sala de Leitura da Escola Celso Leite Ribeiro Filho}

Ao alcançarmos o plano onde a pesquisa se realizará de maneira efetiva, além dos registros fotográficos, os apontamentos no diário de bordo passam a ser utilizados com maior frequência. Parte das informações assinaladas a partir deste trecho do presente documento também é resultado dos diálogos mantidos com o professor, igualmente transcritos no diário de bordo.

\footnotetext{
24 Informações extraídas do endereço http://porta Isme.prefeitura.sp.gov.br/Escolas/094633/Defa ult.a spx
} 
A Sala de Leitura da Escola Celso Leite Ribeiro Filho consiste em um ambiente bem amplo e iluminado, abastecido tanto por luz artificial quanto natural. Com exatos 32 metros quadrados, ela é cercada por prateleiras de maneira com base de tijolos, com oito mesas redondas distribuídas aleatoriamente e seis cadeiras em cada uma. Uma de suas paredes separa o ambiente leitor de uma quadra poliesportiva de onde, inevitavelmente, em todos os períodos chegam ruídos consequentes das diferentes práticas propostas pelo professor de educação física.

A Sala de Leitura é um dos espaços mais seguros da escola. Para chegar até ela, é necessário passar por duas portas metálicas e dois portões, com direito a trinco e dois cadeados cada, além de um corredor estreito que separa os dois conjuntos de barreiras. As janelas também recebem o reforço de grades de proteção e uma espécie de tela de aço, que protegem os vitrôs.

O acervo de impressos, controlado por intermédio de livros de carga, registravam, em 20 de abril de 2011, 5280 títulos que teriam chegado ao longo dos últimos seis anos: 231 em 2005, 264 em 2006, 660 em 2007, 2112 em 2008, 1485 em 2009 e 528 em 2010. Metade deste material é constituída de livros didáticos, direcionados às áreas do conhecimento que fazem parte do plano pedagógico, tais quais matemática, geografia, história, etc., além de coleções voltadas ao aperfeiçoamento dos próprios docentes, com referências à pedagogia e à crítica literária, por exemplo.

A outra metade, composta por livros literários, é fortemente marcada pelos livros infantis e infanto-juvenis, com algumas obras voltadas aos clássicos, em especial nacionais ou de língua portuguesa, aos romances, aos livros de poesia e às crônicas, além de suspense, terror e mistério.

Há quantidade significativa de livros da atualidade, especialmente que se tornaram sucessos de vendas e bastante consumidos pelo público jovem. Constam da lista pelo menos três cópias dos sete livros que integram a saga de Harry Potter. Os livros da série “Crepúsculo” também são encontrados em mais de um exemplar. As aventuras mitológicas de Rick Riordan, como "O Ladrão de Raios”, além de "O Código Da Vinci”, são outros que figuram no acervo da escola.

Curiosamente, outros títulos não necessariamente voltados ao público adolescente, mas que também são líderes de venda, como “A menina que roubava 
livros”, “O Caçador de Pipas” e “A Cabana”, estão presentes e em número significativo.

Paralelamente ao acervo de livros, há uma pequena DVDteca, um aparelho televisor de 29 polegadas, um aparelho de som, um aparelho de DVD, um home theater, um datashow, um microcomputador, um laptop e uma tela de projeção.

Talvez por ser uma sala ampla, observamos também que o local é utilizado como uma espécie de depósito. Monitores desativados, caixas de computadores e material pedagógico, a princípio dissociado de práticas leitoras, ficam espalhados pelo chão, em partes das prateleiras e em cima de algumas mesas, que, como percebemos, não estão inteiramente à disposição dos alunos.

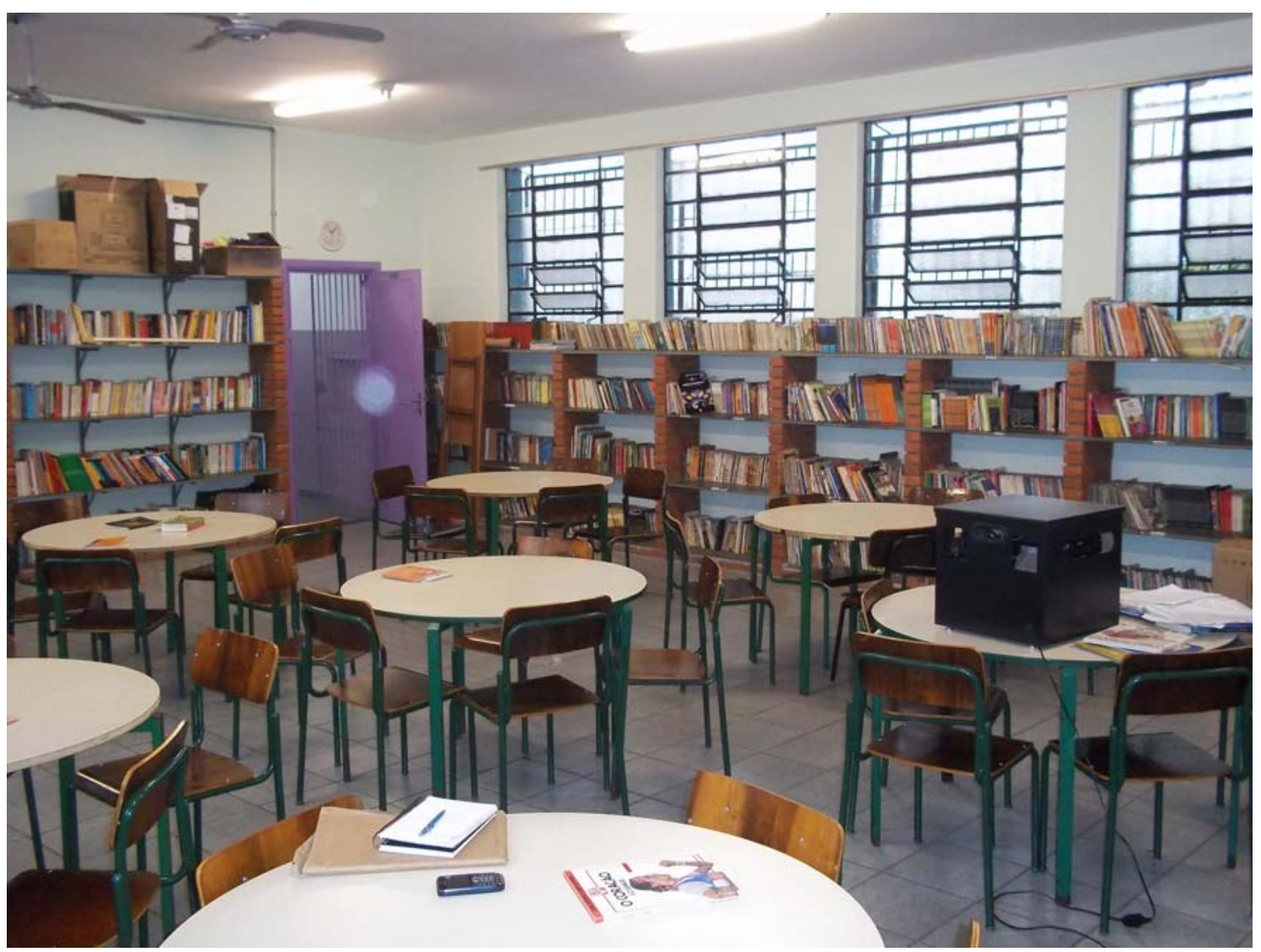

Figura 13 - As mesas redondas e alguns livros espalhados, o datashow, as caixas intrusas ao fundo 


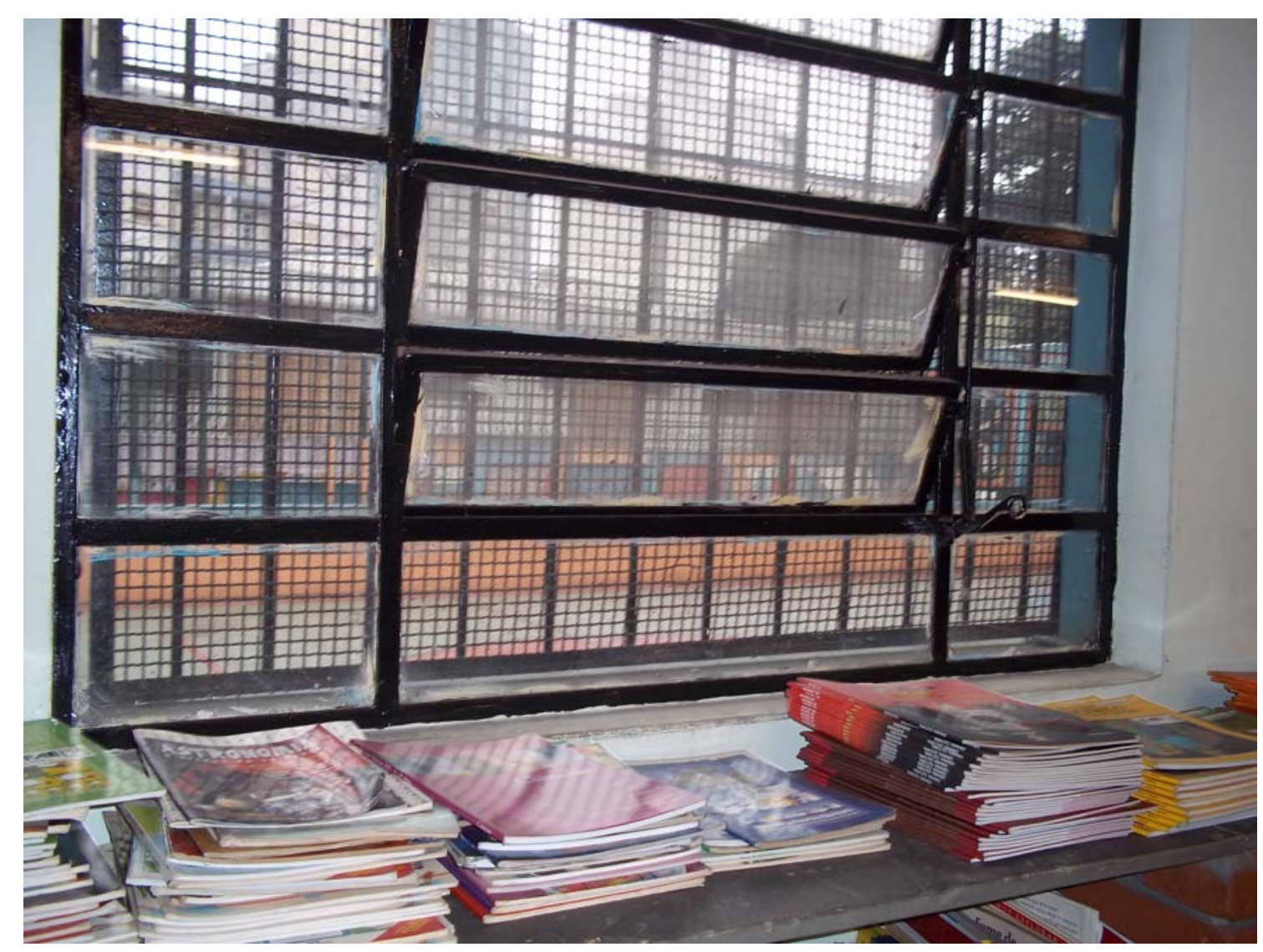

Figura 14 - O conjunto de grades que protegem as janelas. Do lado de fora, a quadra poliesportiva 


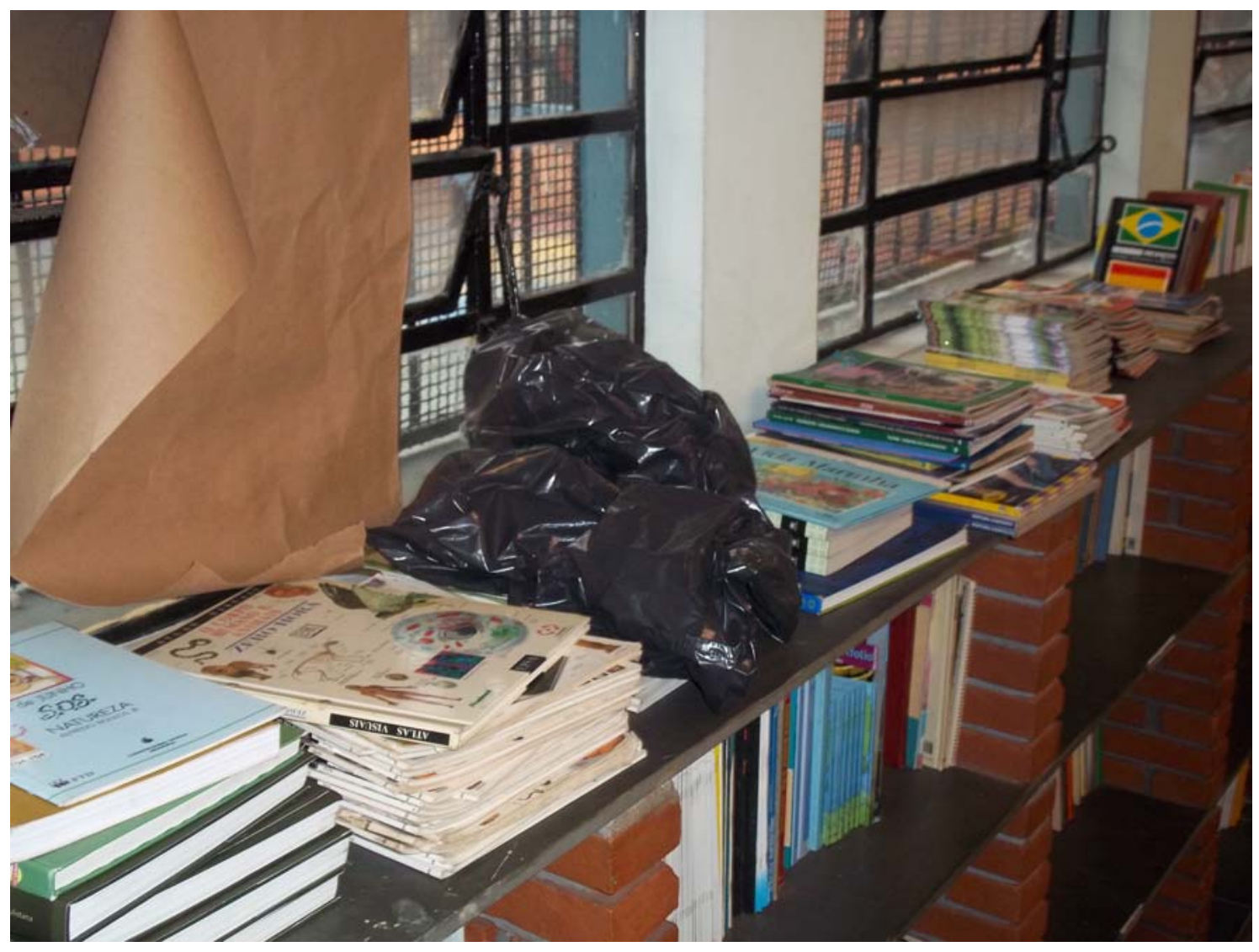

Figura 15 - $O$ papel pardo improvisa reparo na janela. E um saco preto onde não deveria estar 


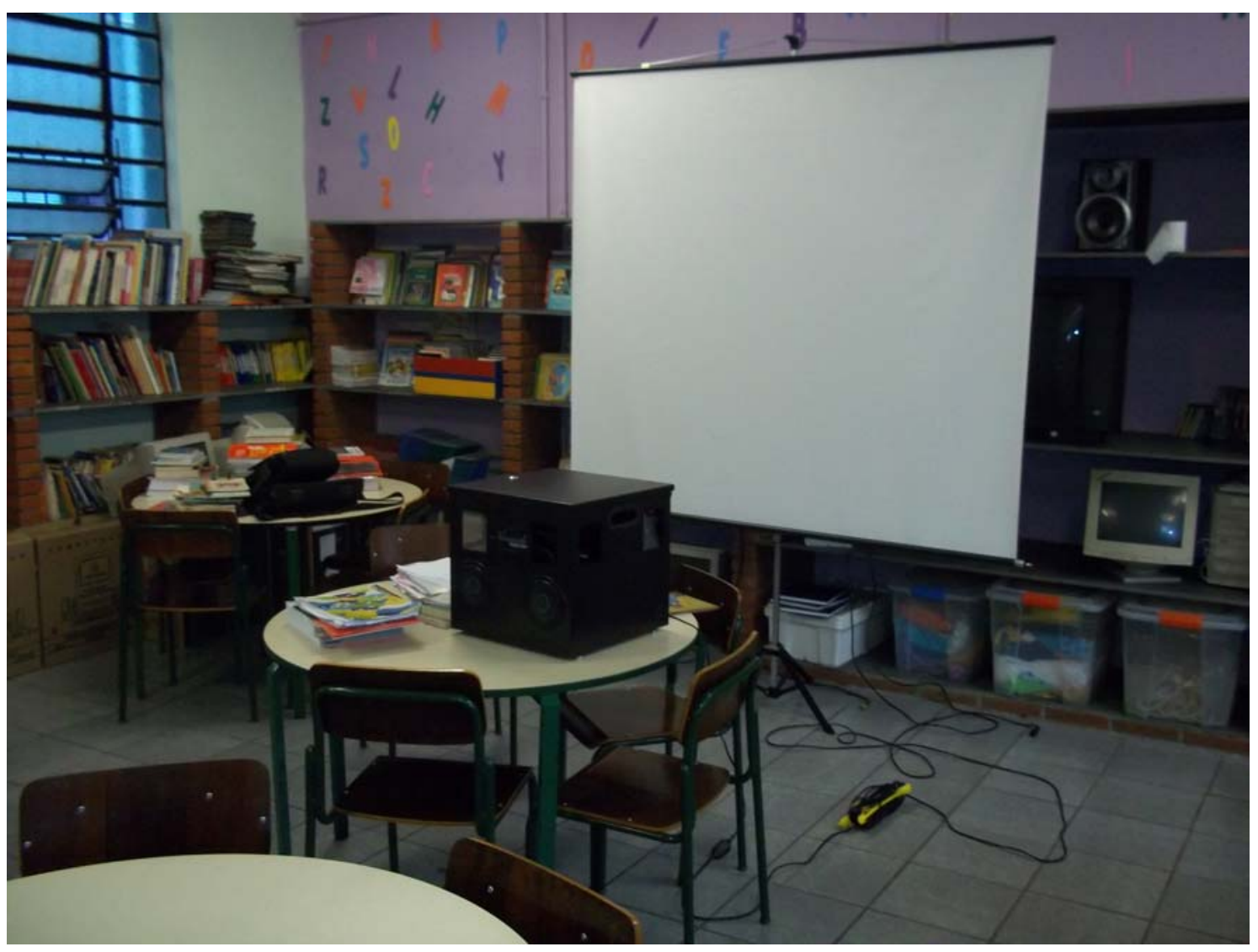

Figura 16 - Outras plataformas de leitura: a tela de projeção, o computador, a TV, o DVD e o som 


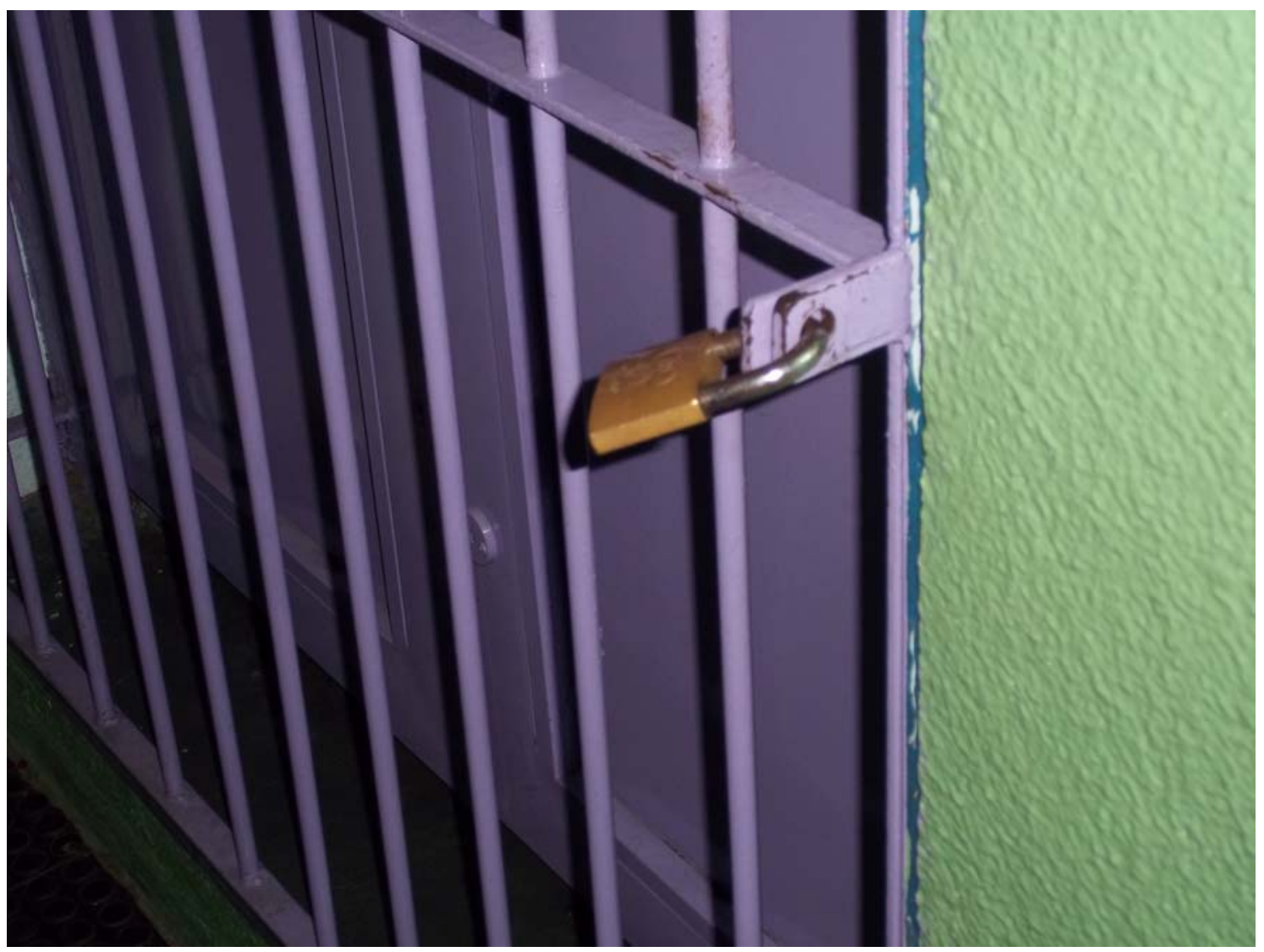

Figura 17 - Cultura guardada e protegida

Os livros não são organizados de uma forma burocrática, também não tomam como referência a influência de modelos encontrados em bibliotecas para o tombamento e catalogação. Eles são apenas organizados nas estantes, por assunto, que são identificadas por intermédio de registros textuais afixados nas próprias prateleiras. Mas, dentro deste universo e organização temática, os títulos ocupam os espaços de maneira aleatória, sem um critério, por exemplo, como o de ordem alfabética, por título ou por autor etc.

O processo de tombamento é feito por intermédio de registro no já mencionado livro de carga. O ano, o autor, o título, o gênero, o número de páginas, uma numeração para controlar o tamanho do acervo, além do visto do professor catalogador são as informações básicas nele transcritas. Atualmente o histórico das doações, desde a abertura da Sala de Leitura, soma 9,3 mil volumes.

Depois de catalogados, os livros recebem um carimbo, que indica que eles pertencem à instituição e, em seguida, são expostos no acervo para consultas ou empréstimos, que podem ser realizados tanto por alunos, quanto por professores e demais funcionários. 


\subsection{Um trabalho de observação}

Finalmente atingimos o momento da aula. E reiteramos que é nesse ambiente que se dá a principal investida de nossa pesquisa de campo. É onde pretendemos investigar de maneira mais determinada nosso problema de pesquisa. Afinal, poderiam, de fato, os meios de comunicação, à revelia das críticas frequentes dirigidas a eles, aproximar os jovens dos livros? A interação, imersão e integração, ao longo de 10 aulas (equivalentes a dois meses e meio) a um pequeno grupo social, formado por professor e alunos de nono ano que se reúnem de maneira sistemática, semanalmente, em sala de leitura, tinham como finalidade encontrar respostas para este questionamento e àqueles que são imediatamente decorrentes dele: o discurso dos meios de comunicação circula nesse ambiente? De que maneira? Por quem? Só por alunos? Por alunos e professores? Ele é estimulado? Valorizado? É possível constatar, por meio deste fluxo, destes diálogos, o direcionamento para a prática leitora?

Inspirada por este leque de indagações de propósito comum, esta abordagem do estudo etnográfico se alinha e ocorre em concomitância com os outros instrumentos até aqui utilizados, dos quais constam o levantamento documental, o registro fotográfico e a contextualização da cultura na qual os estudantes objeto da análise estão inseridos. Convém frisar que, com base nas referências bibliográficas acerca de trabalhos que se apoiam em técnicas de pesquisa do gênero, denominamos a técnica referida de observação participante. Ressaltamos que todo o processo de planejamento, captação e levantamento dos dados considerou as três premissas destacadas por Winkin para que um projeto com tais características seja bem sucedido.

"Para mim, a etnografia hoje é ao mesmo tempo uma arte e uma disciplina científica, que consiste em primeiro lugar em

saber ver. É em seguida uma disciplina científica, que exige saber estar com, com outros e consigo mesmo, quando você se encontra perante outras pessoas. Enfim, é uma arte que exige que se saiba retraduzir para um público terceiro (terceiro em relação àquele que você estudou) e portanto que se saiba escrever.” (1999:131) 
Além de criar instrumentos que nos permitissem apurar a capacidade de saber ver, de saber estar com e de saber escrever, para mais uma vez voltar a Bourdieu, não deixamos de direcionar também a nossa vigília a outra arte, que, somada ao levantamento, compõem as duas partes deste processo de interpretação que caracteriza o estudo etnográfico. Trata-se do método interpretativo ou, como cita Costa, a "hermenêutica”. O desenvolvimento do esforço conjunto, que se faz de variadas perspectivas, por meio de experimentação, da reflexão sobre as circunstâncias e que, neste sentido, transformam o momento da captação e análise em único e indissociável, ainda que aquilo que carregam de individual se mantenha intacto.

“As pesquisas no campo das ciências da comunicação
permitem que se descubram enunciados aparentes e
obscuros, assim como as formulações conscientes e
inconscientes dos discursos. É o princípio interpretativo que,
recusando a unicidade e a aparente simplicidade do mundo,
assume a proposição de sentidos que se instituem e se
complementam por meio de um processo que vai se
constituindo historicamente." (2000:16)

Por esta razão, a reprodução e a produção que integrarão todo o trabalho analítico resultado da observação participante será feita de maneira única. Dito de outra maneira, não haverá um momento da descrição e outro da análise. Ambas ocorrerão em concomitância. Aliás, tais circunstâncias também marcaram o momento que precede este de síntese no qual nos encontramos quando ainda se distinguia e observava o observável de maneira embrionária, seguidas das anotações esquemáticas, que posteriormente se transformavam em transcrição definitiva do constatado e interpretado.

O caminho percorrido foi o da "ciência em via de se fazer". Buscávamos nos apoiar na orientação que toma como parâmetros a necessidade de "descobrir no decorrer da própria atividade científica, incessantemente confrontada com o erro, as condições nas quais é possível tirar o verdadeiro do falso, passando de um 
conhecimento menos verdadeiro a um conhecimento mais verdadeiro”. (BOURDIEU, 1999:17)

Na prática, houve um momento inicial em que predominavam muito mais as incertezas e a falta de clareza a respeito daquilo que seria observado. À medida que as aulas se sucediam, a compreensão sobre a cultura à qual começávamos a nos integrar era aprimorada. A frequente revisão dos primeiros registros, assim como do quadro de referência teórica que embasou a pesquisa, permitiu o desenvolvimento de um modelo esquemático, constantemente complementado, que passou a nortear o olhar do pesquisador.

Desta maneira, ao principiar o ciclo de encontros, tratamos o problema de pesquisa e seus desmembramentos complementares a partir do seu enunciado geral, de forma bastante genérica. À medida que novas aulas aconteciam, a análise, sem perder o olhar holístico inicial, passou a se direcionar também a questões bastante específicas. Tais questões podem se traduzir nas seguintes expressões interrogativas:

- Os alunos utilizam celular na sala?

- Os alunos utilizam aparelhos de MP3, MP4, Ipod ou equivalente para ouvir música?

- Os alunos utilizam outros aparelhos eletrônicos próprios como videogames portáteis, laptop, entre outros?

- Os alunos levam jornais, revistas ou qualquer outro meio de comunicação de massa para as aulas?

- Os alunos comentam sobre filmes, novelas, seriados, programas de auditório, telejornal ou outros programas de televisão?

- Os alunos comentam sobre programas de rádio ou músicas?

- Os alunos que utilizam celular ou qualquer outro aparelho eletrônico ou meio de comunicação de massa o fazem coletivamente ou individualmente? Comentam a respeito? Cantam? É algo participativo?

Buscava-se saber, por outro lado, como o professor se comportava diante destas questões: 
- Ele falava sobre os meios de comunicação?

- Utilizava algum aparelho eletrônico? Celular? Aparelho de música? Computador? Datashow?

- Levava para dentro das aulas questões discutidas pelos meios?

- Estimulava os alunos a fazerem-no?

- Quando via (se via) um aluno, por exemplo, usando o celular, o que ele fazia?

Por fim, buscamos a aproximação com o aspecto central da pesquisa e as possíveis relações existentes entre a eventual circulação do discurso dos media e o interesse dos estudantes pelos livros:

- Os alunos selecionavam títulos relacionados a assuntos discutidos pelos meios de comunicação e levados para dentro da sala de aula? Por exemplo, um filme do Harry Potter estimulava o empréstimo do livro do Harry Potter? Ou mesmo em relação a uma temática? Um filme de mitologia estimulava os alunos a se interessarem por livros de mitologia?

\subsubsection{Plano geral}

A apresentação dos dados seguirá por duas vias distintas e complementares. Na primeira delas, serão retratados alguns aspectos comuns, que não estão restritos às particularidades de determinadas aulas. Os rituais, as propostas coletivas e eventuais menções genéricas, que servem como mais um elemento de compreensão daquele pequeno grupo social, ao mesmo tempo em que são úteis como introdução ao cotidiano das aulas.

Parece oportuno aproveitarmos para destacar que as descrições não serão individualizadas por turma (A, B e C), mas sim apresentadas em blocos. Um dos aspectos observados no transcorrer das reuniões é que o professor orientador da Sala de Leitura, ainda que adote comportamento levemente distinto em relação aos três diferentes grupos, estabelece um plano unificado para todos. Desta maneira, entre os dias 22 de março, quando a observação participante teve início, e 7 de 
junho de 2011, quando ela foi encerrada, ocorreram 10 encontros com cada uma das turmas, em um total de 30 aulas analisadas, que foram agrupadas entre si, uma vez que preservam temáticas indistintas.

Como também não faz parte do escopo deste trabalho realizar comparações entre turmas, entendemos que é perfeitamente possível preservar também na análise o mesmo critério de agrupamento. O que em realidade pautará nosso interesse são as reações, o comportamento adotado, as relações mantidas e os diálogos.

Com o propósito de organizar os relatos e, em certo sentido, já iniciar o trabalho interpretativo e analítico, eles serão divididos por aulas, previamente denominadas aqui, por livre iniciativa do pesquisador, de acordo com a proposta pedagógica apresentada pelo professor de Sala de Leitura. São elas:

AULA 1 - Roda de leitura

AULA 2 - Ficção científica: tentativa frustrada de assistir a episódio de "Perdidos no Espaço"

AULA 3 - Assistindo a "Perdidos no Espaço"

AULA 4 - Professor sem voz: aula livre

AULA 5 - 0 herói

AULA 6 - $O$ herói - Parte II

AULA 7 - Problemas com o pen drive: aula livre

AULA 8 - Assistindo a "Guerra de Titãs"

AULA 9 - Excursão: aula livre

AULA 10 - Festa junina: aula livre

Para não cairmos em repetições desnecessárias, destacamos que o professor de Sala de Leitura adotava um comportamento padronizado no início de todas as aulas. As três salas de nono ano se localizam no segundo andar do prédio principal. Ele percorre, portanto, o corredor de acesso à secretaria, passa pelas três portas (inclusive a elétrica) que dão acesso a um pátio fechado, sobe quatro lances de escada, entra na sala de aula convencional, faz chamada e depois retoma o caminho de volta acompanhado pelos alunos. Em geral, o percurso leva entre sete e dez minutos. Algumas vezes, a porta elétrica está fechada ou na ida ou na volta ou nos 
dois caminhos. Tais impedimentos contribuem para fazer com que o início da aula atrase ainda mais.

Ainda sob o dentro deste plano geral, o perfil de circulação das obras é um aspecto que chama a atenção. Os alunos podem pegar por empréstimo até três títulos, inicialmente com prazo de uma semana para a devolução, mas que não tem de ser rigorosamente seguido. No início de cada aula, o professor checa o controle e pergunta aos alunos sobre os livros, que, muitas vezes, não são devolvidos no dia determinado. As solicitações de ampliação do período para a entrega são corriqueiras.

O sistema de empréstimo e devolução, diga-se de passagem, é bem simples. Algumas folhas pautadas são colocadas junto com a lista de chamada da turma e ali são marcados apenas o nome do aluno, as obras retiradas e a data. Quando elas retornam ao acervo, o professor apenas passa um traço sobre o nome do aluno e registra “devolvido” para efetuar a baixa.

Considerando-se o objetivo da pesquisa, que trata da possível contribuição dos meios de comunicação de massa para despertar o interesse dos alunos pelos livros, algumas reflexões foram realizadas a partir das preferências observadas nos empréstimos. Uma das referências para a análise foi a lista publicada pelo caderno Sabático, que circula aos sábados no jornal O Estado de S. Paulo, dos dez livros de ficção mais vendidos no Brasil. Ao resgatarmos aquelas que cobriram o período de um ano, entre os dias 18 de junho de 2010 e 19 de junho de 2011, verificamos que 66 títulos e 34 autores estiveram presentes nas 51 semanas de circulação. Destas obras, 17 integram o acervo da Sala de Leitura.

Durante as dez semanas de acompanhamento das aulas, houve uma verificação paralela de como se dava a dinâmica do empréstimo destes livros e o resultado indica que eles estiveram praticamente apenas nas mãos dos estudantes, mal parando nas prateleiras da Sala de Leitura. Como revela o quadro abaixo, cada um deles ficou, em média, 8,41 semanas emprestado.

Um ponto que não pode ser ignorado é que, deste universo, cinco títulos foram recém-adaptados diretamente para o cinema ou para séries de TV e são acessíveis por intermédio da programação da TV a cabo. São eles: A Guerra dos Tronos, Alice do País das Maravilhas, Diário do Vampiro - Reunião Sombria, O Ladrão de Raios e O menino do Pijama Listrado. 
Outros cinco estão relacionados a adaptações, e podem ser considerados continuações, que possivelmente terão suas versões para as telas. São os casos de Amanhecer, quarto título da série Crepúsculo, de Stephenie Meyer, A Batalha do Labirinto, A Pirâmide Vermelha, O Mar de Monstros e O Último Olimpiano, todos escritos por Rick Riordan.

\section{Livros da lista dos mais vendidos do Caderno Sabático (de 18/06/2010 a 19/06/2011) disponíveis na Sala de Leitura}

\begin{tabular}{|c|c|}
\hline TÍTULOS & NÚMERO DE SEMANAS \\
\hline A Batalha do Apocalipse & 7 \\
\hline A Batalha do Labirinto & 6 \\
\hline A Cabana & 10 \\
\hline A Guerra dos Tronos* & 10 \\
\hline A Maldição do Titã & 9 \\
\hline A Menina que Roubava Livros & 9 \\
\hline A Pirâmide Vermelha & 8 \\
\hline A Princesa e o Sapo & 6 \\
\hline Alice no País das Maravilhas** & 9 \\
\hline Amanhecer - Livro 4 & 10 \\
\hline $\begin{array}{l}\text { Diários do Vampiro - Reunião } \\
\text { Sombria*** }\end{array}$ & 10 \\
\hline O Ladrão de Raios**** & 10 \\
\hline O Mar de Monstros & 10 \\
\hline O Menino do Pijama Listrado***** & 7 \\
\hline O Pequeno Príncipe $e^{* * * * * *}$ & 7 \\
\hline O Último Olimpiano & 8 \\
\hline Os Heróis do Olimpo & 7 \\
\hline Média & 8,41 \\
\hline \multicolumn{2}{|c|}{ * Inspirou série de televisão que estreou em 17 de abril 2011 no canal fechado HBO } \\
\hline \multicolumn{2}{|c|}{$\begin{array}{l}\text { ** A adaptação mais recente estreou em } 27 \text { de maio na rede Telecine } \\
\text { *** Inspirou série de televisão veiculada desde novembro de } 2009 \text { no canal fechado } \\
\text { Warner Channel } \\
\text { **** A estreia do filme na rede Telecine ocorreu em } 29 \text { de janeiro } \\
\text { ***** A estreia do filme na HBO ocorreu em } 1 \text { de outubro de } 2010 \\
\text { ****** Recebeu uma adaptação ao cinema em 1974, mas não a consideramos } \\
\text { relevante para esta pesquisa, uma vez que tal adaptação não é exibida nas telas. } \\
\text { Segundo a programação das redes de TV aberta e fechada, ele não foi veiculado } \\
\text { sequer uma única vez no decorrer do primeiro semestre de } 2011\end{array}$} \\
\hline
\end{tabular}


Os setes livros que compõem a série Harry Potter também estiveram entre os mais procurados pelos alunos. Durante todo o trabalho de observação na Sala de Leitura, apenas um dos títulos, Harry Potter e a Pedra Filosofal, esteve disponível e somente em uma das aulas. Os demais, sem exceção, estavam sempre emprestados, com procura, inclusive, durante as aulas. Frequentemente alunos perguntavam a respeito de algum título ou eram cobrados pelo professor em função do grande interesse.

Convém lembrar que os sete livros já tiveram adaptação para o cinema. O último, que foi desmembrado em dois filmes, teve a primeira parte exibida em novembro de 2010 e a segunda estreou em julho, quando já havíamos finalizado o trabalho de observação. Os cinco primeiros já foram veiculados tanto na TV fechada quanto aberta. A exceção fica por conta de O Enigma do Príncipe, cuja estreia se deu em 4 de setembro, na HBO.

Como indica o quadro, os livros ficaram com os estudantes por 9,86 semanas em média.

\section{Livros da série Harry Potter disponíveis na Sala de Leitura}

\begin{tabular}{|l|r|}
\hline TÍTULOS & NÚMERO DE SEMANAS \\
\hline Harry Potter e a Pedra Filosofal & 9 \\
\hline Harry Potter e a Câmara Secreta & 10 \\
\hline Harry Potter e o Prisioneiro de Azkaban & 10 \\
\hline Harry Potter e o Cálice de Fogo & 10 \\
\hline Harry Potter e a Ordem da Fênix & 10 \\
\hline Harry Potter e o Enigma do Príncipe & 10 \\
\hline Harry Potter e as Relíquias da Morte & 10 \\
\hline Média & $\mathbf{9 , 8 6}$ \\
\cline { 2 - 2 }
\end{tabular}

Um terceiro grupo de livros foi considerado na análise. Trata-se dos quatro títulos que compõem a saga Crepúsculo. Todos eles foram publicados no Brasil e apenas um ainda não foi adaptado ao cinema - o já citado Amanhecer. Crepúsculo, o filme, teve exibição em TV aberta e fechada, Lua Nova faz parte da grade de programação do canal de TV a cabo Telecine desde 20 de outubro de 2010 e Eclipse estreou em $1^{\circ}$ de junho de 2011. 
Tais obras são bastante disputadas, como mostra o quadro abaixo. O primeiro da série, o próprio Crepúsculo, foi o único que pôde ser eventualmente encontrado. Os demais estavam sempre emprestados, o que contribuiu para que a média de permanência com os estudantes fosse de 9,25 semanas.

\section{Livros da série Crepúsculo disponíveis na Sala de Leitura}

\begin{tabular}{|l|r|}
\hline TÍTULOS & NÚMERO DE SEMANAS \\
\hline Crepúsculo & 7 \\
\hline Lua Nova & 10 \\
\hline Eclipse & 10 \\
\hline Amanhecer & 10 \\
\hline Média & $\mathbf{9 , 2 5}$ \\
\cline { 2 - 2 }
\end{tabular}

Para complementar a análise, aproveitamos para verificar em que medida livros que contam com temática similar à apresentada por este conjunto de títulos amplamente expostos pelos media poderiam ser procurados com maior assiduidade pelos alunos. Para citar apenas um tema como exemplo, identificamos quatro obras no acervo que contavam com o termo vampiro no título. São elas: Entrevista com o Vampiro, de Anne Rice, Dente de Vampiro, de Tommy Donbavand, A Mudança do Pequeno Vampiro e O pequeno Vampiro, de Sommer-Bodenburg. Todos estiveram emprestados por pelo menos 7 semanas neste período, o que sinaliza um desempenho bastante acima da procura geral pelas obras disponíveis no acervo.

Vale ponderar que, de acordo com o controle do professor de Sala de Leitura, considerados os números gerais, isto é, a movimentação que envolve a escola como um todo, três alunos por turma fazem empréstimos e cada um pega em média 2,5 livros por semana. Admitindo que os 1166 estudantes são divididos em turmas de 35, temos cerca de 100 estudantes que fazem empréstimos semanais. Nesta perspectiva, no transcorrer de dois meses seriam acumuladas em torno de 2,5 mil retiradas.

A soma das publicações até aqui mencionadas, quais sejam, as que figuram no caderno Sabático, das séries Crepúsculo e Harry Potter e aquelas que têm os 
vampiros como tema, alcança 31 títulos. Eles acumularam, no mesmo período, 287 empréstimos e ficaram em posse dos alunos por 9,25 semanas.

Por outro lado, o acervo total da Sala de Leitura é de 5280 títulos. Se subtraídas as obras citadas e os 2 mil livros voltados para a formação e interesse dos próprios professores, o montante restante, que poderíamos classificar de livros não midiáticos ${ }^{25}$, seria reduzido a 3,2 mil exemplares. Confrontados os títulos disponíveis com os 2,2 mil empréstimos registrados é possível concluir que cada uma destas obras ficou menos de uma semana (precisamente 0,68) fora do acervo da Sala de Leitura.

Se comparados os fatores $(9,25$ e 0,68), é possível perceber que o grau de interesse por aqueles livros que recebem maior exposição nos meios de comunicação é 13,6 vezes maior do que a média geral de todo o acervo.

É claro que os números devem ser absorvidos com parcimônia. Trata-se de referências generalizadas, que não traduzem rigorosamente o real. Entretanto, elas permitem uma leitura mínima acerca da acessibilidade e do interesse por determinados temas, contextos e características.

Mesmo se fizermos um corte mais rigoroso e considerarmos, por exemplo, apenas $15 \%$ de todas as obras disponíveis para os alunos como as mais procuradas entre as obras não midiáticas, ainda assim seriam valores significativamente distintos. Em um acervo de 488 livros, teríamos uma média de 4,5 semanas de empréstimos, isto é, menos da metade dos números obtidos pelos livros midiáticos.

No contexto apresentado, parece razoável aceitar que a ampla exposição, que combina cinema, TV, internet, vídeos e jogos para videogames e computadores, entre outros, os quais podem reverberar nas conversas cotidianas manifestas nas interações sociais no ambiente escolar, contribuiria para estabelecer conexões e dar sentido ao literário. Motivados pelas suas experiências e a superexposição ao mundo, que, nos dias de hoje, tem se tornado cada vez mais digital, os alunos encontram extensões, complementos e principalmente novas formas de experimentação e leitura na plataforma impressa.

\footnotetext{
${ }^{25}$ Consideramos não midiáticos os livros que não foram adaptados e exibidos em salas de cinema ou canais de televisão (abertos ou fechados) no decorrer do último semestre nem tiveram uma leitura para as plataformas de videogame mais populares, tais quais Xbox, Playstation, Wii, etc.
} 


\subsubsection{Plano específico}

Se até aqui tratamos das características gerais relacionadas aos encontros matinais de terças e quartas-feiras, em Sala de Leitura, deste ponto em diante, abordaremos as aulas individualmente, com a análise de situações vivenciadas, frequentemente apoiada em levantamento documental e consultas bibliográficas. Tal reflexão obedecerá a sequência das aulas, com títulos elaborados pelo próprio pesquisador para cada uma delas, lembrando que não haverá distinções entre turmas, de forma que as descrições serão corridas, como se fossem únicas, com o registro misto dos fatos observados nas três turmas, baseado no problema e objetivos da pesquisa e nas questões que deles decorreram.

\section{AULA 1 - Roda de leitura}

Esta foi, sem dúvida, a aula mais atípica. Nela, fomos oficialmente introduzidos ao grupo por meio de apresentações formais ao professor de Sala de Leitura e às três turmas. Os grupos ficaram visivelmente desconfortáveis em função do elemento estranho, cuja presença, por mais que tivesse sido explicada, não foi assimilada de imediato. As inevitáveis comparações com aulas posteriores demonstram formas de comportamento bastante diferentes tanto do docente quanto dos alunos. O mestre, mais comedido, olhava-nos constantemente, parecia medir palavras, fez algumas menções aos meios de comunicação. Os estudantes, por seu turno, mantiveram-se quietos e disciplinados, postura incomum se comparada à maioria das outras nove aulas que se seguiram.

Quando chegamos à Sala de Leitura, nem o professor nem os alunos estavam em sala de aula; provavelmente faziam o percurso entre salas.

Aos poucos, alguns estudantes foram aparecendo. Notamos que cinco estavam com fones de ouvido e um deles, uma garota, segurava uma edição da revista Billboard com a cantora Lady Gaga ${ }^{26}$ na capa. O periódico estava aberto em uma página cuja matéria abordava o tema nanotecnologia. Observamos também

\footnotetext{
${ }^{26}$ Edição no 17, de março de 2011.
} 
que havia uma variedade de aparelhos que permitiam aos jovens ouvir música: três celulares e dois aparelhos que tocam MP3.

O professor surge entre os alunos, nós nos apresentamos e falamos rapidamente sobre expectativas para os dois meses seguintes. Em seguida, somos convidados a entrar no ambiente onde havia um conjunto de 27 cadeiras formando um círculo.

A aula é dedicada efetivamente à leitura. Após o anúncio, parte do grupo se queixa, uns se revoltam, dizem que não vão participar, mas outros, em compensação, mostram ansiedade pela oportunidade de recitar trechos do texto em voz alta.

Exemplares do texto A menina do fio $^{27}$ são distribuídos entre eles, que riem, fazem chacota e conversam sobre outros assuntos. Dois garotos falam animadamente a respeito de algo que um deles teria visto no YouTube. "Você assistiu o vídeo do padre que sacou a arma e começou a atirar num veado que está no chão ${ }^{28}$ ?” Diante da negativa do colega, o rapaz começa a explicar.

Enquanto os alunos e a sala eram preparados para o início da leitura, aquela edição da revista Billboard Brasil circula entre os alunos. Os fones continuam nos ouvidos. Um dos garotos ameaça contar para o professor. Um se rende às ameaças e os retira da orelha. Os demais simplesmente ignoram.

O professor começa a contextualizar o texto. Fala que a história se passa no Oriente Médio. Lê um parágrafo e, em seguida, passa a incumbência para o aluno ao lado, que lê um trecho e repassa para outro e assim sucessivamente. Apesar do silêncio, nota-se certa desconcentração. Os livros estão abertos, mas poucos acompanham a leitura. Outra garota está com a revista da Lady Gaga. Os fones continuam nas orelhas. De repente, o mestre para e comenta um trecho. “Alguém aqui conhece a Turquia?” Silêncio absoluto. Um garoto devolve a pergunta. “Fica perto do Egito ${ }^{29}$ ?”

\footnotetext{
${ }^{27}$ STELA, Barbieri. A menina do fio. São Paulo: Girafinha, 2006.

${ }^{28}$ Durante a pesquisa, os conteúdos dos medias mencionados pelos alunos sempre foram pesquisados. Alguns deles, é o caso desta menção, não puderam ser encontrados. De resto, na medida do possível, sempre citaremos as referências.

${ }^{29}$ No dia 12 de fevereiro de 2011, o ditador Hosni Mubarak renunciou à presidência do Egito depois de intensos conflitos, inclusive por intermédio dos media, que movimentaram o noticiário internacional no primeiro trimestre de 2011. Fonte: http://veja.abril.com.br/noticia/internacional/omundo-celebra-a-queda-de-hosni-mubarak
} 
Na tréplica, o mestre pondera e recomenda. "Fica mais ou menos perto sim do Egito. Mas façam o seguinte: pesquisem na internet assuntos sobre a Turquia. Verifiquem onde fica este país, quais são as características culturais dele, em que eles se diferenciam de nós.”

Imediatamente, um estudante, que aqui chamaremos de Vinícius ${ }^{30}$, retira um smartphone do bolso e pergunta: "Professor, o que tem de pesquisar?” Dois alunos ao lado também se interessam pela atividade e se movimentam para acompanhar o amigo. O professor, ao perceber que o aluno começava a busca, procura retomar a aula. "Não, gente, agora não. Façam isso em casa ou na aula de informática.”

Diante da negativa, alguns ainda lançam mão de apelos, mas o professor diz que é importante retomar o texto.

Vinicius e seus colegas continuam entretidos com o aparelho eletrônico por uns dois, três, talvez quatro minutos, quando o professor pede que o celular seja desligado. Eles ainda resistem por um tempo (cerca de três minutos) e só param depois da insistência. "Por favor, desliguem o celular."

Há uma notável frustração no ar. Pelo menos estes três garotos já não estão mais atentos ao texto. De resto, a mobilização criada em torno da possibilidade de pesquisa se transformou mais uma vez em dispersão. A sensação que fica é de que a oportunidade de estimular uma leitura mais participativa se perdeu em prol da ideia de linearidade, no entendimento de que não se pode perder o foco do texto.

Alguns parágrafos mais tarde, o professor interrompe mais uma vez para falar sobre um aspecto característico da cultura turca. "Na maioria dos países mulçumanos, um homem pode ter mais de uma esposa. O que vocês pensam disso?”

Uma aluna, Juliana, faz menção à telenovela $O$ Clone $^{31}$. "É mesmo. Na novela da tarde tem um homem com várias mulheres. A Jade usa aqueles panos na

\footnotetext{
${ }^{30}$ Os nomes que eventualmente serão mencionados são figurativos. Servirão apenas para ligar fatos a determinados alunos. Em relação a Vinícius, chama a atenção o fato de que ele é um estudante que frequentemente está com aparelhos eletrônicos diferenciados nas aulas. Além de um aparelho celular Verizon Motorola DROID 2, ao longo dos encontros ele esteve com um laptop, e um Psp Slim (um PlayStation de mão).

${ }^{31}$ A telenovela, que já havia sido exibida uma vez, voltou ao ar no dia 10 de janeiro de 2011 e esteve em exibição durante todo o período de realização da pesquisa. Fonte: http://blog.jovempan.uol.com.br/parabolica/bastidores/o-clone-estreia-em-janeiro-no-vale-a-penaver-de-novo/
} 
cabeça. As mulheres têm de usar aquela roupa preta que esconde tudo. Como chama aquilo professor?” "Burca."

Outra jovem, Rafaela, aproveita o tema para também perguntar. "Professor, por que elas têm que usar aquelas roupas?” “É uma questão cultural e religiosa. Faz parte das crenças.”

Dentre as personagens do livro, há uma que se chama Ariadna. O professor, desta vez, interrompe o texto para fazer menção a referências da mitologia. "Que importante personagem mitológica tem esse nome?” Um aluno responde rápido: “Ariadne é o nome daquele ‘traveco’ do Big Brother ${ }^{32}$, não é não?” Todos riem, menos o professor, que parece não ter entendido. Aliás, não comenta o fato. Juliana toma a palavra. “Ariadne é filha de Minos, não é? Aquela que se apaixonou por Teseu $^{33}$, não é?”

O professor concorda, faz elogios a Juliana, diz que ela pega emprestado muitos livros e é uma garota inteligente.

A leitura, então, continua, até que a aula acaba. Não foi possível ler o texto inteiro.

Já nesta primeira aula, alguns elementos chamaram nossa atenção. Em primeiro lugar, a presença dos media em sala não apenas na forma discursiva, mas também física. A revista, os aparelhos de MP3 e a música, a telenovela, o Big Brother, a internet, o noticiário internacional. Em segundo lugar, eles foram utilizados como referência para a interpretação, compreensão ou para estabelecer simples paralelismo ao texto. Ora o professor, ora os alunos se remetiam a eles para questionar, raciocinar, discutir. Em terceiro lugar, os produtos dos meios de comunicação despertam o interesse dos alunos. Os momentos de participação coletiva se deram principalmente quando se comentou a respeito da novela $O$ Clone e fizeram menção ao Big Brother. E em quarto, apesar de permitir tais conexões, o professor tende a evitar o aprofundamento. A preocupação é sempre de retomar o texto e não se perder dele.

\footnotetext{
${ }^{32}$ A edição de 2011 do Big Brother Brasil, transmitida pela Rede Globo de Televisão, contou com a participação de uma transexual chamada Ariadna. Durante a realização desta aula, o reality show ainda estava sendo exibido.

${ }^{33}$ Esta é a primeira de muitas manifestações relacionadas à mitologia ao longo das aulas. O fato chamou muito a atenção. É notável o quanto os alunos demonstram conhecer razoavelmente bem o tema. Não demorou muito para lançarmos mão da hipótese de que tal familiaridade com o tema se deu por conta do fenômeno O Ladrão de Raios e do jogo God of War.
} 


\section{AULA 2 - Ficção científica: tentativa frustrada de assistir a episódio de “Perdidos no Espaço”}

O professor inicia a aula com problemas técnicos. Tenta por quase meia hora fazer funcionar um aparelho de DVD. Nós o ajudamos, mas o equipamento eletrônico simplesmente não liga. A intenção é passar um vídeo para apresentar aos alunos o tema ficção científica. Para ser mais preciso, ele deseja exibir o primeiro episódio da série "Perdidos no Espaço ${ }^{34}$."

Ele decide, então, fazer chamada e conferir a lista de livros emprestados. Negocia devoluções com alunos. Uma jovem, Lúcia, pergunta sobre A Cabana. O professor alega que ainda está emprestado, mas que irá reservá-lo e tão logo o receba de volta emprestará para ela. Um garoto, Jeferson, pergunta sobre O Mar de Monstro. Neste caso, o mestre parece menos otimista. Diz que demorará um pouco, uma vez que existem quatro outros alunos na fila. Assim mesmo, anota o nome dele.

Concluídas as formalidades, e ainda sob o impacto da pane no DVD, o professor lança a pergunta: "Pessoal, o que é ficção científica?”

Diferentemente da outra aula, os alunos estão sentados em volta das mesas redondas espalhadas pela sala. Mais acostumados conosco, eles estão à vontade para conversar, brincar entre si, e muitos nem sequer dão atenção para a pergunta: sete estão com fones de ouvidos (duas meninas dividem o mesmo e cantam baixinho), um garoto escreve mensagens via celular, outro lê jornal de esportes, e há uma revista Gloss ${ }^{35}$ circulando entre um grupo de garotas.

Muitas vozes competem com a do professor, que chama a atenção de um dos garotos que está ouvindo música. “Gabriel, desliga isso, senão eu vou tirar de

\footnotetext{
${ }^{34}$ Seriado de TV norte-americano, produzido nos anos 60 e que contava as aventuras da família Robinson.

${ }^{35}$ Revista voltada para o público feminino, jovem e/ou adolescente. A edição de fevereiro, de número 41, traz a atriz Isis Valverde na capa e entre as manchetes estão: Bocão Tudo! Famosas mostram como usar os batons da vez, Horóscopo Chinês - As surpresas do ano do coelho, Amor Medo de namorar tem cura e Compre seu orgasmo - Brinquedinhos incríveis para a hora $\mathrm{H}$.
} 
você.” E lança novamente a pergunta: “Alguém aqui sabe o que é ficção científica?”

Exatos quatro alunos prestam atenção. Um deles responde: “Tipo Transformers ${ }^{36}$, professor?”

O docente parece não entender. “Transformers? O que é isso?”

Outros cinco alunos se juntam à conversa. Instala-se o tumulto. Uma meia dúzia se adianta para responder. O professor se situa. “Ah, sim. Dos robôs. É... digamos que é um misto de ação e ficção científica. Digamos que vocês estão na linha. Mas alguém aqui já leu Júlio Verne? Alguém conhece?”

Ninguém se manifesta a respeito.

Pelo menos metade da turma está entretida com celular, Ipod e revista. Três estão entre as prateleiras e buscam alguma obra que possa ir ao encontro dos seus interesses.

O professor pega uma pilha de livros cujo título é As crônicas marcianas ${ }^{37} \mathrm{e}$ começa a distribuir alguns entre as mesas. "Vamos lá, gente. É importante que vocês leiam alguns dos clássicos da literatura universal. Julio Verne foi um dos principais autores do que podemos chamar de ficção científica.”

Parte dos alunos - para ser exato, seis - passa a folhear os livros e ver ilustrações. Em geral, aqueles que não participam das conversas animadas, muito embora um deles tenham se isolado dos colóquios só depois que um exemplar chegou às suas mãos.

Cinco garotas cantam baixinho "você, você, você, você, você, você, você quer? ${ }^{38,}$

O professor começa a ler um trecho da primeira história. Pede que os estudantes o acompanhem. Poucos acatam. Dentre eles, há um garoto com fones de ouvido ligados a um aparelho celular. De tempos em tempos, interrompe o quê? A

\footnotetext{
${ }^{36}$ Produção cinematográfica norte-americana, baseada em série de desenho dos anos 80 em que robôs se transformam em veículos (os Autobots). Dois filmes já foram lançados e foram campeões de bilheteria. Um terceiro tem estreia prevista para agosto de 2011.

${ }^{37}$ BRADBURY, Ray. As Crônicas Marcianas. Rio de Janeiro: Globo, 2005.

${ }^{38}$ Hit cantado pela Mulher Melão e que teve ampla aceitação, sobretudo pelo público jovem, no primeiro semestre de 2011 por meio das performances da funkeira no programa Pânico na TV, exibido pela Rede Record de Televisão.
} 
aula?. Parece mudar de música ou estação. Talvez esteja enviando ou respondendo mensagem de texto. Em dado momento, simplesmente se desliga do redor.

Ao término da aula, o nível de ruído é grande. Com o esvaziamento da sala, o professor está visivelmente cansado. "Eles são difíceis. São poucos os que gostam de ler. Você vê? A maioria fica conversando e, se eu não controlo, fica todo mundo ouvindo música e mexendo no celular.”

Alguns pontos merecem destaque neste segundo encontro. Em primeiro lugar, mais uma vez os media se fazem presentes. Ao lado das conversas cotidianas, sobre namorados, festas, discussões e afins, eles são predominantes nas conversas. Em segundo, a fragmentação do todo, com os alunos ocupando as diversas mesas redondas, provocou uma descoletivização da leitura e, por consequência, fez com que ela alcançasse um número menor de alunos. Terceiro, apesar dos inúmeros signos, das incontáveis vozes midiáticas, podemos afirmar que o professor não se aproveitou de nenhuma. Nem mesmo, assim como fez na aula anterior, com a tentativa de estabelecer relações e paralelismos.

\section{AULA 3 - Assistindo a "Perdidos no Espaço"}

Tudo está preparado. Projetor, aparelho de DVD e telão. Como de costume, o professor faz chamada antes de encaminhá-los à Sala de Leitura e anuncia a “sessão de cinema”. Os alunos ficam eufóricos com a notícia e começam a esvaziar rapidamente a sala de aula. Mesmo sem terem ouvido falar sobre a série ou, em alguns casos, sabendo apenas que se trata de um produto midiático antigo, não se queixam, não reclamam e até são mais rápidos do que se verificou até então.

Como temos notado desde a primeira aula, boa parte dos jovens está com fones nos ouvidos ou entretida com as teclas do celular. Fabiano reclama que o professor demora muito para dar início à exibição. "Desse jeito a gente não vai conseguir ver quase nada.”

O professor começa a explicar os motivos que o levaram a apresentar para os estudantes Perdidos no Espaço. Vozes de impaciência começam a pedir que o orador não demore. “Olha, gente, lembram-se do que conversamos na aula passada? 
Sobre ficção científica? Então, a ideia hoje é passarmos um pouco do filme e depois discutirmos a respeito.”

O aparelho é ligado e o silêncio é absoluto dentro da sala. É a primeira vez que o barulho externo - alto, diga-se de passagem - de alunos fazendo educação física é perceptível do lado de dentro. O professor se incomoda, começa a fechar as janelas, mas os alunos parecem não se importar. Continuam atentos às imagens que se desenrolam.

Entretanto, o comportamento dos espectadores é um tanto quanto dinâmico. Uma garota, por exemplo, está com fone em uma das orelhas, lê $A$ menina que roubava livros, por duas vezes olha o celular, além, é claro, de assistir ao filme. Sua atenção se prende a Perdidos no Espaço especialmente nas cenas de maior suspense, valorizadas por trilhas sonoras típicas. Em certos momentos, ela simplesmente esquece o livro. Fica ali, uns bons cinco minutos como que hipnotizada.

Pelo menos dois terços da sala mantêm postura similar. Parecem tomados por certa inquietação. Constantes interrupções para comentários, rápidas conversas paralelas, um garoto e uma garota trocam torpedos entre si durante todo o tempo de exibição, o que, por outro lado, não indica que estavam desinteressados.

Um dos indícios de que os alunos estavam de alguma forma atentos ao filme é a maior interatividade e participação quando o professor interrompe a sessão - o que, cabe dizer, gera protestos. Uma quantidade muito maior de alunos quer falar. E os debates giram em torno de questões variadas. Rafael, se concentra no que ele chama de tosqueira. "Muito mal feito o macacão de alumínio. E aquele robô ridículo?”

Renato lembra que em Morde e Assopra ${ }^{39}$ há uma mulher robô. E Pedro faz uma intervenção bastante curiosa: ao se referir às produções antigas, age como se o mundo fosse sem cor no passado. "Professor, mas se naquele tempo tudo era preto e branco, como o senhor pode falar que a cor da roupa deles é prateada? Não era tudo preto e branco?”

\footnotetext{
${ }^{39}$ Morde e Assopra é uma novela da Rede Globo, que estreou em 21 de março de 2011. Na trama, a atriz Flávia Alessandra encarna o papel de um andróide.
} 
Danilo, por sua vez, lembra de Star Trek ${ }^{40}$. "Essa série aí lembra aquele filme que tem o Spock. Os caras ficam no espaço também... Jornada nas estrelas. Minha mãe falou que ele é bem antigo. Esses dias passou uma versão nova. Eu assisti. Está passando direto no Telecine.”

Outros cinco garotos se manifestam em relação ao filme. Todos teriam assistido por meio de uma versão pirateada que um deles teria comprado. "O pai do Maurício comprou uma cópia num 'fornecedor' aqui no centro que a gente é cliente e depois que eles assistiram passaram pra gente. Bem louco.”

A aula termina e os alunos não arredam pé. Não querem ir embora. Pedem para que o professor da Sala de Leitura tente se entender com o de Geografia de maneira que todos continuem ali. O mestre diz que não pode, que outra turma terá aula também. Os estudantes solicitam, então, que o filme seja retomado do ponto em que parou na aula seguinte.

Antes de saírem, 12 alunos solicitam empréstimos de livros. Foi, sem dúvida, a aula em que o interesse foi mais expressivo. Ao todo, 25 títulos foram registrados no controle do professor e, embora ficção científica tenha prevalecido, não foi o único campo de interesse. Suspense, aventura, terror e mistério estiveram também na lista dos escolhidos.

O episódio de Perdidos no Espaço indiscutivelmente foi a atividade que mais despertou o interesse dos alunos até o momento. Ainda que a produção tenha quase 50 anos, uma eternidade para produtos do gênero, revelou-se mais eficiente que os próprios livros para estimular práticas leitoras. Prendeu a atenção, mobilizou os alunos, estimulou discussão mais ampla e participativa. Talvez tenha sido pura coincidência, mas o nível de empréstimos só vai se aproximar do observado nesta aula quando, mais uma vez, o professor trabalhar com filme, na oitava aula.

O intercâmbio de cópias pirateadas de filmes como Star Trek nos permite afirmar que a circulação dos produtos midiáticos, que tem início em sala de aula, extrapola este ambiente e alcança outras esferas das relações sociais. A família, os amigos e outros grupos eventuais aos quais os jovens se integram e utilizam como locais de veiculação, de reverberação, de tráfego de comunicação. As orelhas pontiagudas da personagem mais famosa do filme, a reprodução do "V" com a mão

\footnotetext{
${ }^{40}$ Um remake de Star Trek foi filmado em 2009. Em 28 de agosto de 2010, o filme passou a ser exibido em canal fechado, mais especificamente no Telecine.
} 
imortalizado por ele, os efeitos especiais, as armas que soltam raios, o uniforme que mais se parece com pijama... Imagens, sons, hábitos, histórias que povoam o cotidiano, integram diálogos, despertam interesses.

Ainda que não seja especificamente o tema do presente trabalho, acreditamos ser importante fazer menção ao ritmo, ao comportamento, ao percurso percorrido pelos alunos durante o momento da leitura - é evidente que consideramos aqui uma abordagem mais ampla, em que os media, por exemplo, podem representar uma forma de leitura. Nota-se que ela não é mais linear, que é feita aos saltos, com interrupções; é realizada a partir de múltiplas combinações signicas, que provavelmente interferem no processo de produção de sentido. $\mathrm{O}$ barulho na quadra, a música, o celular, a internet, as mensagens via celular, os parágrafos dos livros, o próprio filme: todos e cada um são plataformas, são produções e conteúdo, que representam ao mesmo tempo formas e possibilidades individuais, mas também coletivas de leitura. E é possível que as razões que permitem esta relação de aproximação, este interesse e atratividade por determinados formatos passem necessariamente pelo comportamento fragmentado, inconstante e repleto de descaminhos que caracterizam o que é ser estudante hoje em dia.

\section{AULA 4 - Professor sem voz: aula livre}

O professor está sem voz. Diz que não sabe o motivo. Talvez uma gripe forte, talvez por falar demais, talvez por ter de gritar para disputar a atenção com os alunos. Comenta que a aula será livre. "Peguem o livro que quiserem, mas sugiro que vocês retomem o tema da última aula. Por isso, separei alguns livros aqui.”

Ele espalha todos os títulos na mesa central. São 21 e todos um tanto quanto antigos. Dentre eles, Da Terra à Lua, Admirável Mundo Novo, Eram os Deuses Astronautas? e Viagem ao Redor da Lua.

Boa parte da turma se aproxima, mas a maioria continua entretida em conversas, aparelhos de celular, aparelhos de MP3. Uma garota, aliás, exibe um Ipod. Vinícius, o mesmo que na primeira aula tentou fazer uma pesquisa na internet, hoje está com um laptop e reúne sete garotos ao seu redor por conta dos 
jogos que tem instalados nele. Animam-se para jogar futebol no aparelho; negociam a ordem dos competidores e dos times.

Depois de quase 20 minutos de aula, apenas nove alunos pegaram livros. Michele resolve tomar por empréstimo $A$ máquina do tempo ${ }^{41}$, enquanto, entre os demais, apenas três efetivamente estão lendo. O restante se espalhou entre as rodas de conversas animadas em torno das mesas espalhadas pela sala.

Impaciente, o professor se aproxima das mesas. "Vocês não vão ler nada?” Vai até o grupo de Vinícius e pede que o aparelho seja desligado. O garoto tenta negociar, quer apenas cinco minutos. Diante da recusa, diz que se trata de um jogo de ficção científica. O mestre continua irredutível e afirma que aquela aula é para ler, não para jogar. O estudante insiste e acaba conseguindo permanecer com o computador ligado.

Em uma mesa, seis jovens ouvem música. Um reclama que o fone está com problema, outro que o cartão de memória do celular já está no limite da capacidade. A conversa, então, se volta para as músicas. "Você tem alguma coisa da Lady Gaga?” “Tenho.” “O quê?” “Bad Romance.” “Muito louca essa música.” “Deixa eu

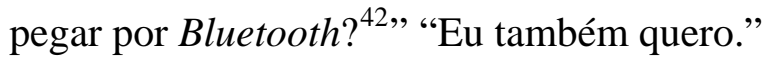

Em menos de um minuto, todos estão ouvindo a mesma música, em três aparelhos celulares distintos.

O diálogo se estende para um vídeo amplamente divulgado na internet, que ficou conhecido como Gordinho Zangief ${ }^{43}$. Trata-se de registro feito por câmera em uma escola australiana no qual um aluno ofendido pelos colegas aplica o mesmo golpe executado por uma personagem do jogo Street Fighter, conhecida como Zangief.

Todos riem muito ao relembrar as cenas, que, somadas, não atingem mais que um minuto. Juliana acessa o Youtube YouTube pelo celular e carrega o vídeo. Os amigos se espremem para ver a tela do celular. Eles comentam, dão gargalhadas.

A conversa muda bruscamente de rumo quando André pergunta se Juliana tem alguma música do Luan Santana no celular. A garota faz que sim com a

\footnotetext{
${ }^{41}$ WELLS, H.G. A máquina do tempo. São Paulo: Alfaguara Brasil, 2010.

${ }^{42}$ Tecnologia que permite a troca de informações e arquivos via celular por meio de frequência de rádio de curto alcance.

${ }^{43} \mathrm{O}$ vídeo, que se transformou em coqueluche nos primeiros três meses de 2011, pode ser acessado por meio do link http://www.youtube.com/watch?v=NMxn3Cf0JtI
} 
cabeça, mexe no celular e o restante a acompanha, cada um com o seu próprio aparelho. Menos de um minuto depois, já fazem coro baixinho. "Um beijo fala mais que mil palavras, um toque é bem mais que poesia...”

Paulo, que está reunido com outros sete garotos, fala sobre Entrevista com o Vampiro" 44 "Velho, eu assisti no domingo à noite, na HBO [TV paga]. Muito louco. Bem melhor do que essa viadagem de Crepúsculo.”

Danilo discorda. “Ah não, cara, acho louco Crepúsculo. Assisti o filme no cinema, comprei depois para ter em casa, li o livro. Bem louco.”

Fernando, que completa o trio, não gosta de livros. "Nunca li um livro inteiro. Nunca. Não consigo, não gosto. Sou mais ver o filme. Se tem o filme, pra que o livro?”

O professor se aproxima. “E aí pessoal, nada de leitura por aqui?”

Paulo aproveita para fazer uma consulta. "Professor, o senhor tem livro sobre vampiros aqui?”

“Temos aqueles Crepúsculo e Lua Nova... não me lembro de todos os títulos de cabeça, mas são esses do filme...”

“Ah, professor, acho chato esse aí.”

“Mas temos outros também. Esses dias chegaram vários. Vem aqui. Dá uma olhada na parte do terror."

Paulo acompanha o professor e Fernando comenta. "O professor fica falando tanto de livro, deixa essa sala trancada quando tem que sair um pouco, não para de dizer que é importante ler, não sei o que... Do jeito que ele fala, parece que livro é dinheiro. Você acha que alguém vai roubar isso daqui?!” Ele aponta para os equipamentos eletrônicos e emenda: “Aquele [aparelho de] DVD, sim, alguém pode querer roubar. Agora, esses livros...”

O diálogo entre o professor e Paulo continua. Apresentado para alguns títulos, que folheia sem interesse, finalmente o estudante descobre duas obras que o motivam. O próprio Entrevista com o Vampiro e O Vampiro Lestat, ambos de Anne Rice. "Velho, eu nem sabia que tinha livro do filme..."

“... O filme que é baseado no livro”, corrige o professor.

\footnotetext{
${ }^{44}$ Filme baseado no livro de mesmo nome da escritora Anne Rice. A versão cinematográfica teve lançamento em 1994 e tem no elenco Brad Pitt, Tom Cruise e Antonio Banderas.
} 
“... e tem esse outro aqui. Velho, o Tom Cruise é o Lestat no filme.”

A animação em uma das rodas fica por conta do Programa Profissão Repórter exibido na noite anterior. ${ }^{45}$ A Rua Taguá, localizada atrás de uma grande universidade e a menos de um quilômetro da escola, foi alvo da reportagem, que deu destaque ao consumo excessivo de álcool e às festas promovidas a céu aberto em períodos de aula.

O local é frequentado pelos alunos da Celso Leite Ribeiro Filho. Pelo menos é o que sinaliza o tom dos diálogos. Eles conhecem inclusive uma das personagens de maior destaque da reportagem, apelidado de Neymar por se parecer com o jogador de futebol. “Aposto que a polícia vai ficar em cima agora. Vocês vão ver, as festas não vão acabar. Agora a gente vai ter de arrumar outro lugar pra ir de sexta à noite.”

Ricardo se aproxima do professor. Diz que gostaria de ler histórias em quadrinhos e é conduzido para uma área onde estão armazenadas somente obras do gênero. Ele passa uns bons dez minutos entretido, folheando, lendo um pouco. Separou dois exemplares, mas enquanto faz o empréstimo reclama das poucas opções disponíveis.

O mestre pede que o aluno faça uma lista de sugestões para compra, que será incorporada a um pedido formal a ser encaminhado para a Secretaria de Educação. Entre as sugestões anotadas estavam Pequenos Milagres, de Will Eisner, e Estórias Gerais, de Wellington Srbek.

Curiosamente os dois livros de histórias em quadrinhos são voltados ao público adulto. O primeiro é biográfico e retrata experiências de um jovem judeu no período da Grande Depressão Americana. O segundo é nacional e nele um jornalista investiga a história de um cangaceiro, que viveu no interior de Minas nos anos 20 e era conhecido pela violência e pela barbárie que praticava.

Diante do interesse tão específico e que aparentemente foge ao perfil do aluno, fizemos uma abordagem para tentar compreender o que teria motivado a aproximação. Ricardo fala que foi o tio quem o fez se interessar por histórias em quadrinhos. Colecionador especialmente de séries de super-heróis, como $X$-Men, Homem-aranha, Batman e Sandman, ele compartilhava a leitura com o sobrinho,

${ }^{45}$ O programa foi exibido na noite de terça-feira, 19 de abril de 2011. 
com quem também debatia a respeito do encaminhamento de certas histórias, personagens e poderes.

"No começo, eu seguia o gosto dele e lia o que ele me dava. Com o tempo, fui criando o meu próprio gosto.”

"Mas o que te levou a se aproximar deste tipo de HQ? Eles me parecem tão diferentes.”

"Primeiro eu comecei a comprar vários mangás por causa de desenho [animado] e jogos no PC... tipo Cavaleiros do Zodíaco... eu ia nos sebos aqui no centro e comprava por um, dois reais. Aí, por acaso, eu comprei um gibi desses ali naquele sebo da Líbero Badaró e desde então eu sou meio viciado.”

"E livro, você lê?”

“Leio. Eu gosto bastante. Prefiro quadrinhos, mas gosto de Luis Fernando Verissimo, de Graciliano Ramos, de Ruth Rocha, li todos os livros do Harry Potter que tem aí, meu tio me deu os dois do Tolkien: Senhor dos Anéis e O Robbit. Você viu que vai ter o filme do Robitt ${ }^{46}$ ?”

Na aula mais flexível até aqui, na qual os alunos podiam escolher o livro que bem entendessem e que o professor pouco interveio - basicamente por meio das abordagens nas mesas, sem longas conversas, até porque ele estava sem voz -, o que se verificou foi a ampla utilização de aparatos e a viva circulação dos discursos e dos produtos dos media. Games, internet, troca e audição coletiva de músicas, vídeos, conversas sobre filmes, histórias em quadrinhos.

Foi a primeira vez que observamos, de forma tão concreta, um aluno se aproximar de determinado livro a partir de um filme. A relação estabelecida entre a versão para a TV de Entrevista com o Vampiro e os títulos literários com a mesma abordagem é clara. O impacto gerado no jovem e a temática atraente provavelmente fizeram com que ele procurasse o livro.

Não podemos, por outro lado, ignorar o depoimento do colega, que se mostrou desinteressado pela versão impressa, independentemente das condições em que ela se apresenta, se faz ou não alusão ou é uma literal adaptação de outra plataforma. "Se tem o filme, para que ler o livro?"

${ }^{46}$ J.R.R. Tolkien é o autor da obra que inspirou a saga em três partes de $O$ senhor dos Anéis. Também escreveu $O$ Robbit, que, na verdade, é anterior, mas cuja versão cinematográfica será lançada em 2012. 
As HQ como possível suporte a outras formas de leitura é outro ponto que vale destacar. O múltiplo interesse por videogame, desenho animado e histórias em quadrinhos parece ter contribuído para a aproximação de obras literárias. A própria opção por comics voltados para o público adulto talvez seja um sinal desta tendência.

Por fim, há que se destacar que, apesar desse fluxo intenso da comunicação, o docente parece trabalhar mais no cerceamento que na utilização. Passou boa parte do tempo solicitando (sem sucesso) que celulares e o laptop fossem desligados. Mesmo quando o aluno fez menção ao filme assistido, não procurou valorizar o fato, por exemplo, disseminando o assunto para o resto da sala.

Seja pela orientação pedagógica, inclusive verificada na própria legislação que especifica as práticas na Sala de Leitura, seja pelo despreparo ou desinteresse por este ecossistema comunicacional, seja por definitivamente não gostar destes produtos, temos a impressão até aqui de que o professor propõe formas de estreitar a relação entre os estudantes e os livros que desconsideram elementos essenciais da cultura destes jovens, do contexto em que vivem e de suas preferências.

Cabe mencionar, entretanto, que ao fazermos tais ponderações não estamos deixando de levar em conta outros aspectos que envolvem o professor, com provável impacto nas aulas em sala de leitura. Reconhecemos que a questão é mais complexa e envolve, por exemplo, a falta de infraestrutura, limitações relacionadas à formação, à pressão que ele sofre da sociedade e por parte da própria escola em relação ao conteúdo programático, além da má remuneração, que obriga o educador a enfrentar longas jornadas, em diferentes unidades escolares.

As precárias condições de trabalho, a ausência de incentivos e a desvalorização do profissional de educação também são inibidores da sua capacidade criativa. Elas minimizam as possibilidades de o professor enfrentar com desembaraço as novas demandas sociais, considerando as variações das realidades dos alunos, e o levam a priorizar métodos que, não raro, são menos eficientes.

\section{AULA 5 - 0 herói}

O professor começa a aula dizendo que o tema é "herói” e que trouxe um material em slide para expor à turma. Por dificuldades técnicas, como falta de cabo 
para conectar o computador ao projetor, o início da apresentação tem um atraso de 25 minutos.

Neste ínterim, os alunos, como na maioria dos encontros, organizam-se em torno das mesas, falam, sacam seus celulares, ouvem música em seus fones comunitários, trocam arquivos. Em relação às outras aulas, o número de Ipods subiu para três, há também um Black Berry e Vinícius, o mesmo do smartphone e do laptop, desta vez está com um videogame de mão. Joga Harry Potter e a Ordem da Fênix, que guarda relação com o quinto livro e, por consequência, com o quinto filme da série.

Cinco garotos falam sobre a semifinal da Liga dos Campeões da Europa ${ }^{47}$. Júlio fala que Neymar joga melhor que Messi. Pedro discorda. Para ele, os dois atacantes argentinos (Messi e Tevez) são os melhores do mundo. Todos arriscam seus palpites e fazem observações a respeito de outros jogadores e dos técnicos das duas equipes.

Com a ajuda de Bruno, o professor consegue finalmente fazer o datashow funcionar e começa a exposição. Ou melhor, tenta. Dado o tumulto generalizado, ele tem dificuldade de se fazer ouvir. Pede silêncio. A algazarra continua. O mestre se aproxima dos grupos, pede que celulares sejam desligados, alguns resistem e só se sensibilizam após ameaças.

Resta Vinícius. E, mesmo depois dos insistentes pedidos para que o aparelho seja desligado, o jogo continua. Aliás, o estudante está sentado em uma posição na qual seria impossível ver o telão.

A aula está em curso, o professor fala a respeito de determinadas características do herói, definições, tenta estimular a participação dos alunos com perguntas. Mas os apelos, até aqui, não estão funcionando. Eventualmente alguém tenta responder ou falar alguma coisa. A maioria não presta atenção. Menos de dois minutos depois, os fones já estão de volta aos ouvidos, mensagens em forma de torpedos são intercambiadas e Vinícius continua a fazer o que estava fazendo desde o começo: joga videogame.

\footnotetext{
${ }^{47}$ A Liga dos Campeões é um campeonato de futebol que reúne os melhores clubes Europeus e é realizada no primeiro semestre. Um dos dois jogos realizados entre Real Madrid e Barcelona aconteceu no dia 27 de abril de 2011, exatamente no dia desta aula.
} 
A reação dos alunos diante de longos parágrafos sobre slides brancos parece seguir um padrão. A impressão que temos é de que passado o primeiro contato e assimilado o formato, a atenção já não se volta mais para a projeção. Ninguém lê. Alguns começam a falar. O professor se irrita, pede silêncio, pega um dos celulares dos alunos. Os outros são momentaneamente guardados. Apenas momentaneamente.

Surge a imagem do Batman e do Super-homem em uma das lâminas. A maioria dos alunos tem a atenção desviada para a imagem. As conversas paralelas se reduzem. O professor tenta estimular a participação. "Pessoal, me ajudem aí, vai? Vamos enumerar alguns heróis.”

Uma espécie de competição entre os alunos é iniciada, com vozes sobrepostas: Wolverine, Homem-aranha, Hulk, Homem de Ferro e Thor são os primeiros a serem invocados, entre os muitos citados ${ }^{48}$.

Dois garotos cochicham entre si. "Meu, tô muito a fim de assistir Thor ${ }^{49}$." “Eu não. Parece ser uma bosta." "Se liga, cara, eu vi o trailer esses dias e achei bem louco!” “Ah, sei lá, não curti. O que eu queria ver e gostei muito foi de Velozes e Furiosos $5^{50}$."

Alguns slides à frente, o professor faz referência a Tróia. "Quem aqui sabe a história?” Ninguém responde. “Do Cavalo de Tróia.” Ainda nenhuma reação efetiva. “Vão me dizer que ninguém assistiu o filme?” Bruno quer ter certeza: “É aquele com o Brad Pitt ${ }^{51}$ ?” "Isso, esse mesmo.” Muitos se adiantam para dizer que o conhecem. “Do Aquiles, né?” “Meu, o cara era indestrutível e morreu com uma flechada na perna.”

O mestre procura estabelecer relações entre o que descrevia e os comentários a respeito do filme. "Então, essa é uma das características principais do herói. Ele normalmente é dono de um poder que o diferencia dos demais, luta por um objetivo, no caso de Aquiles, pela Glória.”

\footnotetext{
${ }^{48}$ Todos tiveram adaptações recentes para o cinema, além de figurarem nas histórias em quadrinhos e terem suas versões para o videogame.

${ }^{49}$ O filme teria estreia em circuito nacional três dias depois, em 29 de abril de 2011. Naqueles dias, a produção contava com forte apelo nos meios de comunicação.

${ }^{50}$ A estreia em cinemas brasileiros aconteceu em 15 de abril de 2011.

${ }^{51} \mathrm{O}$ filme teve estreia mundial nos cinemas em 12 de maio de 2004.
} 
Faz passagem de uma história a outra, mas permanece entre histórias e personagens da mitologia grega. "E do mito de Perseu, alguém lembra?”

Agora quase a sala inteira está em polvorosa. Muitos querendo falar ao mesmo tempo. Juliana, a mesma que havia sido elogiada duas aulas atrás, toma a palavra. "Perseu é filho de Zeus com Danae e foi jogado ao mar junto com a mãe num caixão logo depois do nascimento... Então professor, é estranho que no filme ${ }^{52}$ a história é contada de um jeito... mesmo nos livros... eu vi duas versões diferentes. Nenhuma é igual à do filme. O que tem de igual é a cabeça da Medusa, a Andrômeda e o monstro do mar.”

Muitos querem falar. Pedro lembra que no livro que leu sobre o mito, o rei da ilha em que Perseu e sua mãe Danae viviam também foi transformado em pedra e que no filme nada disso acontecia. Bruno recorda que em Percy Jackson - O ladrão de raios havia uma Medusa também e que a cabeça dela foi igualmente cortada. Ricardo e Rafael comentam entre si que assistiram aos dois filmes em DVD e que leram não só o primeiro livro da série de Percy Jackson, mas os dois que se seguiram ao que deu origem à versão cinematográfica.

O professor diz que é importante relativizar as adaptações dos livros. “A história nunca vai ser a mesma. Sempre alguma coisa vai ser perdida, no livro é natural que seja mais completo e são comuns as diferentes formas de se contar a história. É por isso que vocês devem ler o livro, para ter um olhar diferente e mais profundo da história.”

O comentário gera controvérsia. Parte discorda. Alguns dizem preferir o filme, entre outras coisas porque a versão impressa é chata. Mas outros, como Pedro, Juliana, Ricardo e Rafael, são defensores do livro, alegam que eles são mais legais e que acham as versões para as telas um pouco incompletas. "Por exemplo, no Harry Potter, o papel do Cedrico é muito maior e mais importante no livro. No filme, ele só aparece no terceiro, quando morre ${ }^{53}$."

A aula chega ao fim e Juliana se encaminha com Renata até a área destinada aos livros de mitologia. Faz o papel de consultora da amiga. Fala sobre títulos, faz

\footnotetext{
${ }^{52}$ A garota se refere a Fúria de Titãs, que é uma refilmagem de uma produção britânica de 1981 e foi lançada nos cinemas brasileiros em 21 de maio de 2010. A estreia na TV fechada ocorreu 15 dias depois desta aula, no dia 11 de maio de 2011, na rede Telecine. O início da exibição estava sendo amplamente divulgado, inclusive em outros canais fechados.

${ }^{53} \mathrm{O}$ garoto se refere a Harry Potter e o Cálice de Fogo.
} 
recomendações e sugere um percurso de leitura. “Comece lendo o Percy Jackson mesmo... melhor, assista o filme, eu te empresto, depois leia o Percy Jackson, aí depois você passa para o Contos e Lendas da Mitologia Grega ${ }^{54}$ e Heróis, Deuses e Monstros da Mitologia Grega ${ }^{55}$. Existem outros aqui, como o Estórias da Mitologia $^{56}$ um, dois e três, mas aí eu acho que você tem que ver se gosta primeiro."

Após observarmos o diálogo entre as jovens, perguntamos para Juliana a origem do seu interesse por livros de mitologia. A jovem tem dificuldades para explicar. Diz que não sabe ao certo. Mas o percurso entre o primeiro contato e a constituição de um interesse concreto ela consegue descrever. "Eu já gostava de Harry Potter lá atrás. Não é mitologia, né? Mas esses todos, Senhor dos Anéis, Harry... tem fantasia... magia... deuses...”

"Mas você assistiu os filmes? Leu os livros?”

“Do Harry eu li os livros e assisti os filmes. Senhor dos Anéis, só os filmes... Mas, então, eu me interessei por mitologia mesmo depois de Percy Jackson. Fiquei apaixonada. Os livros eu li todos antes de comprarem aqui. Eu pedia de aniversário, Natal... agora esses outros eu li aqui.”

“E quanto ao filme?”

“Percy Jackson eu assisti, Fúria de Titãs eu assisti... acho que só, né? Gostei dos dois. Foi por causa do filme do Percy Jackson que eu me interessei pelo livro.”

A propósito, Vinícius sai da sala como entrou. Com o rosto no videogame. Não presta atenção à aula em nenhum momento.

Mais uma vez a aula é marcada pela presença de aparelhos eletrônicos. Eles são, sem dúvida, os maiores motivadores da dispersão. Aqueles que dispõem de um celular, MP3 e videogame fazem uso sem maiores dificuldades. Os pedidos, as ameaças e até as atitudes radicais como retirar o aparelho da mão de um dos estudantes não têm muita eficácia. O comportamento indica que o discurso dos media mais do que circula na sala de leitura. A ideia inicial de que as aulas seriam apenas o local de retomada de produtos veiculados pelos meios de comunicação

\footnotetext{
${ }^{54}$ POUZADOUX, Claude. Contos e lendas da mitologia grega. São Paulo: Companhia das Letras, 2001.

${ }^{55}$ EVSLIN, Bernard. Heróis, deuses e monstros da mitologia grega. São Paulo: Arxjovem, 2004.

${ }^{56}$ PROENÇA FILHO, Domicio. Estórias da mitologia. Rio de Janeiro: Global Editora, 2000.
} 
armazenados na memória foi transcendida. Há o consumo em tempo real, a circulação in loco. E reiteramos, o professor fica à margem deste acontecimento. Não só por ter perdido o controle sobre a sala ou porque demonstra dificuldades de controlar a utilização dos aparelhos, mas simplesmente por não se inteirar deles, por desconhecê-los.

Afinal, o que tanto se ouve nos fones de ouvidos, que são como extensão dos corpos? Que mensagens e arquivos são trocados via SMS, Bluetooth e tecnologia 3G? Que game é esse que é capaz de prender a atenção do aluno por toda uma aula? Que música eles ouvem, do que elas falam, qual a origem? Quais são esses filmes, programas e vídeos de internet que eles assistem e sobre o qual comentam o tempo todo?

Observada a evolução da aula, é perceptível que enquanto a exposição se direcionava para aspectos alheios à vida cotidiana dos alunos e dos significados que eles compartilham com os meios de comunicação, a relação estabelecida era de distanciamento. Com a introdução de elementos reconhecíveis, por exemplo, os super-heróis, que gozam de papel de destaque nas inúmeras produções cinematográficas dos últimos anos e que são superexpostos por intermédio de outras plataformas, como o gibi, o desenho animado e os jogos para videogame, a dispersão se transforma em participação, de forma que, se antes o professor tinha de pedir silêncio em função das conversas paralelas, agora seu esforço é para organizar as falas.

O número de alunos interessados e inteirados sobre mitologia é um ponto que deve ser observado com atenção. Não nos parece mera coincidência o fato de haver uma série de estímulos dos meios de comunicação, em especial os filmes e os games, associados a produções literárias e o conhecimento a respeito de personagens como Perseu, Aquiles, Medusa, Andrômeda e Hades.

Não podemos deixar de evidenciar que, ao longo das dez aulas em que realizamos o trabalho de observação, houve uma intensa exibição dos filmes Percy Jackson e o Ladrão de Raios e Fúria de Titãs nos canais fechados de televisão. Além disso, mais um dos livros da série Percy Jackson foi lançado neste período.

O interesse pela literatura do gênero, observado em Juliana e sua amiga, por exemplo, parece-nos um possível indicador de que os meios de comunicação podem fazer essa aproximação dos jovens em relação aos livros. É o filme que 
desperta o interesse pelo livro, que faz querer conhecer outros filmes e, por sua vez, promove um retorno a outras e mais diversificadas obras impressas.

\section{AULA 6 - O herói - Parte II}

Os heróis, assunto da semana anterior, são retomados. O professor separou cerca de 50 títulos, entre clássicos, literatura infanto-juvenil, gibis e literatura contemporânea. Ele expõe rapidamente aos alunos a ideia: pensar um pouco na aula anterior, nas características básicas do herói, sua composição e tentar estabelecer alguma relação com as obras disponíveis para leitura.

A exposição inicial parece não empolgar. Aliás, o próprio mestre percebe. Os livros, que inicialmente se concentravam em uma mesa, agora começam a ser distribuídos entre os estudantes. Rafael, que recebeu um exemplar de Viagens de Gulliver, comenta com Pedro. "Velho, você assistiu esse filme ${ }^{57}$ ? Muito engraçado. O Jack Black só faz filme engraçado. Tipo aquele Escola do Rock, manja?” Em seguida, começa a folhear o livro ilustrado com interesse maior do que a maioria dos amigos.

Bruno tem comportamento parecido ao selecionar uma edição antiga de $O$ Caso da Jóia Azul, de Sherlock Holmes. Ele mostra o livro para Amanda, Juliana e Ricardo. "Esse filme começou a passar no Telecine faz pouco tempo ${ }^{58}$. É com o ator de Homem de Ferro. Vocês já assistiram? O cara é muito inteligente. Descobre os crimes só pelos detalhes. Animal. E as cenas de luta? A câmera faz uns movimentos loucos. Congela, detalhe. Muito legal. Professor, posso pegar esse emprestado?”

Outro grupo de alunos também fala a respeito de filmes. "Você assistiu Lobisomem ${ }^{59}$ ?” “Assisti. Muito louco.” “E ontem, você viu que passou Hancock na televisão ${ }^{60}$ ? Eu já tinha assistido, mas assisti de novo. O cara é muito engraçado. Tipo... ele nem sabia que não era o único super-herói, que perdia a memória e tal...” “E a cena dele lutando com a própria mulher?” “O pior é que eu acho que deve ser

\footnotetext{
${ }^{57}$ Uma nova adaptação de Viagens de Gulliver para o cinema estreou no cinema brasileiro em 14 de janeiro de 2011.

${ }^{58}$ Sherlock Holmes estreou em 26 de fevereiro de 2011 no Telecine.

${ }^{59}$ Lobisomem estreou em 12 de fevereiro de 2011 no Telecine.

${ }^{60}$ A Rede Globo exibiu o filme Hancock no dia 2 de maio de 2011 na Tela Quente.
} 
bem assim mesmo, né? Já imaginou se tivesse herói de verdade? Os caras seriam isolados mesmo, que nem os X-Men ${ }^{61}$." "Pode crer. Mesmo ajudando a sociedade, todo mundo reclamava dele. Devia mandar todo mundo pro inferno.”

Os hábitos de manipular equipamentos eletrônicos continuam. Pelo menos um terço da sala mexe em algo que toca música, acessa a internet, encaminha mensagens ou tem algum game.

Vinícius trouxe mais uma vez o laptop para a aula. Ele joga com os amigos Perfect World ${ }^{62}$, um dos jogos mais populares de rolling play game (RPG) para PC. O game não é tão novo, mas ao longo dos últimos anos tem sido atualizado. Basicamente o jogador é um guerreiro, que tem uma série de missões a cumprir, que lhe garante mais poder, domínio de territórios e a possibilidade de encarar novos desafios. Trata-se de um complexo jogo de estratégia.

O professor começa a distribuir livros para os garotos que rodeiam Vinicius. "Vai, agora chega. Guarda isso aí. Agora a gente tem de ler um pouquinho.” O jovem resiste, sem tirar os olhos do computador. "Ah, professor, eu não tenho tempo pra ler." "Como assim, você não tempo pra ler? E o tempo que você tem agora?” “Ah, professor, o jogo também é importante. Tem a ver com leitura, com herói como o senhor estava falando.” “Não,Vinícius. Chega, né?” “Como não? Eu já li um livro e tem mais de trezentas páginas.” "Mas não é porque você leu um livro que não precisa ler mais.” "Pra mim já tá bom.” "Você nunca lê. Desliga isso senão eu vou tirar de você. E aí eu vou devolver só para o seu pai.”

O garoto desiste. Salva o jogo e desliga o laptop. Sem computador, nem por isso se rende ao livro. Passa a conversar sem nem encostar no exemplar à sua frente.

Depois que o professor se afasta, abordamos Vinícius. "Eu estava observando as aulas e vi que você sempre está com um equipamento diferente” “Adoro equipamentos eletrônicos. Depois que eu saio da escola, passo a tarde inteira na net e jogando Playstation 3. E eu só paro mesmo porque depois meu pai chega em casa e fica me enchendo o saco.” "E TV, você vê?” "Lógico. Em casa

\footnotetext{
${ }^{61} X$-Men é uma série em formato de histórias em quadrinhos mundialmente conhecida, que conta com cinco adaptações para o cinema. O mais recente foi lançado em 3 de junho.

${ }^{62}$ É o segundo game do gênero com maior número de downloads no sítio Baixaki. Em consulta feita em 3 de julho de 2011, havia 1 milhão de acessos por meio do link http://www.baixaki.com.br/download/perfect-world.htm
} 
fica assim: quando eu estou na internet, deixo o rádio e a televisão ligada. Quando estou jogando videogame, eu deixo baixando arquivo mais pesado no micro." "E você tem banda larga em casa?” “Tenho. Dez megas.” “E TV a cabo?” “Tenho também. Mas quem não tem, né? Normal ou a gato, todo mundo tem.” "E livros, você lê?” “Leio.” “Não aqui, né?” “É... não gosto muito dos livros daqui.” “E que livro você gosta de ler.” “... a Bíblia.” “Algum outro?” “Não.”

Temos a impressão de que Vinícios não lê. Nem mesmo a Bíblia. Seu negócio mesmo são os aparelhos eletrônicos. Nas seis aulas acompanhadas até aqui e nas que ainda serão descritas, o garoto, em nenhum momento, teve uma experiência de leitura. A mais próxima se deu na primeira aula, na roda de leitura, quando o professor não permitiu que ele fizesse a pesquisa sobre a Turquia.

Vinícius parece integrado ao mundo digital e, em contrapartida, desconectado (para utilizar uma expressão própria do meio) do literário. Pelo menos se considerarmos a palavra impressa. O tipo de relação constituída faz parecer que o livro é uma espécie de corpo estranho. Parece haver um abismo entre o universo vivido e experimentado por Vinícius e o que o professor tenta lhe oferecer com a literatura. Ainda que ambos exijam regras complexas de imersão, sistemas de linguagem e interpretação, o segundo não parece tão atraente.

É possível que, neste caso, os aparatos tenham contribuído para afastar e talvez até tenham sido uma das barreiras para a leitura. Entretanto, vale reiterar mais uma vez que o esforço em se estabelecer relações entre o contexto em que o jovem está inserido e as práticas leitoras é mínimo. O jogo, visto como um impedimento, é descartado e o professor nem considera a possibilidade de diálogo.

Sendo um game que mistura fantasia e guerra, não seria possível, por exemplo, trabalhar essas temáticas em sala? Ou propor a Vinícius que fizesse uma palestra sobre o jogo? Por que não aproveitar uma parte da aula em sala de leitura para jogá-lo e, ao mesmo tempo, estabelecer inter-relações entre os jogos e os livros?

Histórias são contadas no decorrer de jogos de RPG como esse. Uma estratégia possível seria recorrer às batalhas épicas presentes nos clássicos e tentar estabelecer paralelos ou mesmo sugerir que os alunos busquem na literatura a solução das charadas impostas pelo game. 
É claro que estamos apenas no plano das suposições. É possível que todas as tentativas se revelem nulas e, por mais que se faça, o aluno continue a não gostar dos livros. Mas, com base nas observações e consequentes reflexões realizadas até aqui, somos tentados a considerar pelo menos dois fatores que podem contrariar esta perspectiva. Por um lado, o aparente interesse identificado entre obras adaptadas a diferentes plataformas, isto é, o livro que vira filme, jogo, desenho animado... e que parecem tornar a leitura, em seus diferentes modos e possibilidades, mais atraente. Por outro, acreditamos que esta abordagem, que busca entender melhor um elemento presente na cultura do estudante - no caso, o videogame -, na pior das hipóteses, oferece ao aluno a oportunidade de uma experiência leitora mais profunda sobre o jogo, a música, o programa de televisão ou o sítio na internet.

Antes de nos despedirmos do professor, perguntamos se ele assistiu ao filme Hancock, sobre o qual os alunos conversavam minutos antes e que está diretamente ligado ao assunto das duas últimas aulas. Ele diz que não e que nem o conhece. Explicamos, então, a proposta e em que medida se aproxima dos debates sobre o herói e suas principais características. Aproveitamos também para mencionar a conversa observada entre os estudantes sobre o filme.

O professor não se empolga com o que ouviu. Temos a impressão, inclusive, de que ele não acha que a ligação entre aula e produto dos meios de comunicação seja tão grande assim. E curiosamente a sensação que nos fica deste diálogo é que, neste caso, poderia ter ocorrido uma espécie de inversão de papéis. O contato direto com algo que lhe é pouco familiar e que eventualmente até fuja do contexto social em que ele está inserido talvez cause estranheza, certo desinteresse, a exemplo do que podemos verificar também com os alunos.

O episódio serve para refletirmos acerca do lugar do professor e dos reais limites de seu papel no esforço em favor da educação. A prescrição, o determinismo, a oferta de caminhos e receitas para que os novos desafios do ensino sejam atendidos tendem a se tornar evasivas se desconsiderados aspectos que cercam a vida do próprio docente. Transferir para ele responsabilidades que não estão circunscritas, apesar de vendidas como capacitação, desenvolvimento de habilidades, reciclagem, etc., é ignorar que, assim como os educandos, o educador está inserido em determinado meio, sob influências das idiossincrasias que o 
caracterizam, e que, portanto, o processo de aproximação de determinados traços culturais, às vezes muito distantes da sua realidade, não raro, sob o risco de representar um desprazer por não traduzir seus gostos e anseios, também terá certo grau de dificuldade, restrições e - por que não? - ineficiência.

\section{AULA 7 - Problemas com o pen drive: aula livre}

A aula deveria ter um rumo, mas por conta de problemas de falta de material didático, teve outro. O professor preparou novamente uma aula em Power Point, mas acabou esquecendo o arquivo em um pen drive que não levou para a escola. Resolve improvisar. A ideia é que o tema da aula seja Poesia. E continuou sendo. Ele explica que havia separado um conjunto de textos e pretendia fazer uma “desconstrução” junto com os alunos. "Mas não tem problema. Eu vou pegar um exemplo aqui, a gente faz uma análise em conjunto e depois vocês selecionam algum livro para fazer individualmente, ok?”

A poesia escolhida pelo professor é Sinal de Apito ${ }^{63}$, de Carlos Drummond de Andrade.

E a mesma dinâmica observada em todas as aulas anteriores volta a se manifestar: dois ou três alunos prestam atenção, quase metade da sala está entretida com aparelhos eletrônicos - inclusive Vinícius, mais uma vez agarrado ao seu videogame de mão -, barulho da quadra, conversas paralelas.

O professor se impacienta. Interrompe a explicação duas ou três vezes. Retoma. Pede que os celulares sejam desligados. Toma um da mão de uma garota. Solicita em vão que Vinícius pare de jogar.

O que há de diferente e que diverte a sala inteira - menos o professor, que não percebe - é uma ponteira eletrônica, que Ricardo trouxe para a aula. O feixe de luz é direcionado a todo instante para a parede, telão, as prateleiras, para os alunos que jogam bola na quadra e para o rosto de outros alunos ${ }^{64}$.

\footnotetext{
${ }^{63}$ Um silvo breve: Atenção, siga./Dois silvos breves: Pare./Um silvo breve à noite: Acende a lanterna./Um silvo longo: Diminua a marcha./Um silvo longo e breve: Motorista a postos. ${ }^{64}$ Em 8 de maio de 2011, portanto, dois dias antes, uma ponteira eletrônica foi um dos destaques do primeiro jogo das finais entre Corinthians e Santos pelo Campeonato Paulista. Jornais estamparam fotos de Elano e Neymar, jogadores do Santos, marcados por uma luz verde e os principais programas esportivos retrataram o assunto.
} 
$\mathrm{O}$ atrativo contribui para que a turma fique ainda mais dispersa do que o normal e o professor acaba interrompendo a explicação na metade. "Hoje vocês não estão muito a fim, né? Mas acho que deu para ter uma ideia da proposta da atividade, certo? Eu gostaria, então, que cada um pegasse um livro desses e fizesse análise das poesias.”

Ao contrário de outras aulas, o professor não circula pela sala na tentativa de assistir os alunos. Está visivelmente irritado e até comenta conosco a respeito do “comportamento estranho dos meninos. O que será que houve? Eles sempre conversam, mas hoje estão completamente fora de controle.”

Um grupo de meninas comenta a participação do cantor Luan Santana na abertura da Fórmula Indy ${ }^{65}$. "Ele é lindo, né, gente? E cantou sem som nenhum. Só a voz dele.” “É, mas você viu que falaram mal?” “Quem falaram mal? Só podem ser uns idiotas.”

Em outra mesa, Rafael lê o jornal diário Lance. Faz previsões sobre a final da Liga dos Campeões da Europa ${ }^{66}$, diz que vai ser difícil o Corinthians segurar o Santos na Vila Belmiro e arrisca um palpite do jogo Avaí e São Paulo ${ }^{67}$. "Ah, velho, o São Paulo vai tomar uma sacolada lá em Santa Catarina. Escuta o que estou falando.”

Há, ainda, na última mesa, um grupo que fala especialmente de séries de televisão. Inicialmente dois garotos discorrem sobre House ${ }^{68}$. "Acho muito louco esse médico reclamão. Eles falam uns bagulhos que a gente não entende nada. Umas doenças esquisitas... tipo lúpus, mas é muito louco.” “O cara gosta de assistir novela, jogar videogame e a equipe dele se mata pra tentar resolver o problema. Ele faz tudo rapidinho.”

Em seguida, a conversa passa para outro produto do gênero. "E Heroes ${ }^{69}$, será que não vai passar mais? Meu, eu fiz cópia das cinco temporadas, acho

\footnotetext{
${ }^{65}$ A corrida aconteceu no dia $1^{\circ}$ de maio de 2011 e Luan Santana cantou o hino nacional na abertura.

${ }^{66}$ A final foi realizada no dia 28 de maio de 2011, às 15h45, com transmissão ao vivo pela Rede Globo.

${ }^{67} \mathrm{O}$ jogo aconteceu na noite de 12 de maio de 2011.

${ }^{68}$ Série de TV exibida em canal fechado pela Universal Channel e que está na sétima temporada. Em canal aberto, a Rede Record é detentora dos direitos e, em 2011, exibe a sexta temporada.

${ }^{69}$ Inspirada em história em quadrinhos, a série de TV exibida em canal fechado e aberto, com cinco temporadas, foi temporariamente interrompida. Suas exibições ocorriam respectivamente no Universal Channel e Record.
} 
demais.” “Quem você acha mais legal?” “Ah! O Sylar, né? E você?” “O Sylar também, mas eu gosto muito do Hiro.” “É mesmo. O japa, além de ter um poder legal, é muito engraçado.”

O professor acompanha conosco a conversa dos alunos. Perguntamos para ele a respeito das séries. "Você conhece?” “Já ouvi falar, mas não assisto não. Mesmo porque eu chego muito tarde em casa e aos sábados e domingos eu quase não paro em casa também. Prefiro mais ir ao cinema quando tenho tempo de assistir a alguma coisa. Depois, não sei se essas coisas são pra mim. Acho que os alunos gostam de umas coisas muito malucas. Acho que é muito efeito especial, raio, tiro... mas falta conteúdo.”

A aula se desenrola entre conversas do cotidiano, como festas, locais de encontro e marcas de roupas, jogos de futebol profissional e séries de televisão. Esta foi a única aula em que nenhum livro foi emprestado. Nenhum. Pareceu-nos que, nesta aula, ninguém teve disposição para ler. Nem que fossem algumas linhas apenas.

Tivemos a impressão, também, que foi o encontro em que menos houve interação entre professor e alunos. A ausência total de referências do cotidiano dos jovens, especialmente relacionado aos media, durante o trecho expositivo da aula, justificaria parcialmente a dificuldade do mestre, que não conseguiu terminar de apresentar o raciocínio. Além disso, é provável que tenha sido determinante para que os livros de poesia simplesmente fossem ignorados. Não houve mínima menção, direta ou indireta, a filmes, histórias em quadrinhos, conteúdo da internet e afins, como observado desde o início da pesquisa.

Ao analisarmos outras aulas, podemos notar que o discurso dos meios de comunicação não só é levado para a sala de aula, mas também ali encontra campo fértil para a veiculação em tempo real, além de amplificar estas possibilidades para o nível da repetição. A ponteira eletrônica, inspirada na repercussão da utilização de um aparelho similar durante uma partida de futebol, estimula a percepção. Tal episódio revela a força e a extensão dos meios de comunicação e sua influência na vida cotidiana dos jovens. 


\section{AULA 8 - Assistindo a “Guerra de Titãs"}

A notícia de que a turma assistiria a um filme durante a aula e de que este filme era Guerra de Titãs ${ }^{70}$ empolga a todos. No percurso entre a sala de aula e a de leitura, alunos conversam animadamente a respeito. Boa parte já tinha assistido, como Pedro, que, apesar de dizer que foram cinco vezes, não se incomodava nem um pouco em viver a mesma experiência pela sexta. "Quando Perseu se vinga de Hades é animal.”

Todos se sentam de maneira organizada. Aliás, o professor já havia cuidado de preparar a sala de maneira que todos tivessem uma boa visão da projeção. Até Vinícius, que nas últimas aulas esteve sempre acompanhado de seu videogame de mão, demonstra interesse, apesar de trazer o equipamento ligado no bolso do casaco.

Antes de dar início à exibição, o professor retoma o mito de Perseu. Lembra o que conversaram sobre as várias versões para a história e que aquela seria uma delas. "Procurem identificar as diferentes personagens, lembrar tudo aquilo que conversamos a respeito do herói e vejam se faz algum sentido.”

O filme começa. De tempos em tempos, o professor faz alguma pergunta a respeito do roteiro, nomes de reis, rainhas, princesas e deuses. “Quem é este?” “Zeus.” “E este?” “Andrômeda.” Em dado momento, são os alunos a se anteciparem. "Esse só pode ser o Hades. Olha a roupa que o cara usa. E depois, todos os outros deuses estão brilhando. Só ele é todo preto, com cara de triste.” "Muito bem, Marquinho, é isso mesmo."

Ao lado da aula três, quando foi exibido um episódio da série Perdidos no Espaço, esta é a aula em que os estudantes estão mais concentrados. Naturalmente isso não impede que o estado de atenção, assim como daquela vez, se manifeste à maneira dos estudantes: fazendo comentários do filme de tempos em tempos, ouvindo música - no caso de Vinicius, com direito a pausas ocasionais para uma jogada ou outra -, encaminhando torpedos, consultando a internet, etc.

\footnotetext{
${ }^{70}$ O filme teve estreia nos cinemas em 21 de maio de 2010. No Telecine, rede de canal fechado, estreou exatos dez dias antes da exibição em aula, em 7 de maio de 2011. Convém destacar, ainda, que a cópia que o professor utilizou era pirata.
} 
Em dado momento, o professor tenta parar o filme para fazer uma explanação a respeito. Os estudantes se irritam. "Deixa rolar, professor. Não vai dar tempo nem da gente assistir tudo. Se o senhor ficar parando, fica difícil.”

Quando, no filme, fala-se de uma maldição em que Hades liberaria um monstro marinho, o Kraken, para destruir uma cidade grega, Rafael faz associação ao filme Piratas do Caribe: O Baú da Morte $e^{71}$ em comentário com Pedro. "É o mesmo nome daquele monstro que destrói o navio do Jack Sparrow, né? Será que o bicho é o mesmo nesse filme? Se for, coitada da Andrômeda.”

O professor para novamente o filme e mais uma vez luta contra o protesto dos alunos. Mas agora se mostra irredutível. "Gente, vamos conversar um pouco sobre o filme, poxa. Senão vocês vão embora e a gente não fala nada.” "Mas e aí, a gente vai ficar sem assistir o resto do filme? Do que vai adiantar também?”

Tem início uma negociação cujo desfecho é a retomada do filme na aula seguinte.

Renata pergunta para o professor se na história real, como no filme, Andrômeda é mesmo salva. É Juliana quem se adianta na resposta. “É, sim. Nas histórias que eu li, ela é sempre salva e da mesma forma. Perseu mostra a cabeça da Medusa para o Kraken e o monstro vira pedra.”

Pedro também tem dúvidas. “Um deus morre? Como se mata um deus?” O professor devolve a pergunta para a sala. “Como é, gente, é possível matar um deus?” As opiniões se dividem. Uns dizem que sim, outros que não. Ele se dirige especificamente para Juliana, que diz que não sabe. Em seguida, passa uma tarefa para os estudantes. "Vamos fazer o seguinte. Vou deixar um desafio aqui para vocês. Pesquisem na internet sobre o assunto. Mas vejam, procurem pesquisar em mais de um lugar e preferencialmente em um site confiável. Aí, na semana que vem, quando voltarmos a assistir ao filme, a gente comenta a pesquisa. Pode ser assim?”

A exemplo do que aconteceu na terceira aula, ao término, um número considerável de alunos se encaminha à mesa do professor para fazer empréstimos. Seis alunos perguntam sobre os livros de Percy Jackson e ouvem que tem de entrar

\footnotetext{
${ }^{71}$ Terceiro filme de um total de cinco, que traz o pirata e capitão do navio Pérola Negra, Jack Sparrow, vivido por Johnny Depp.
} 
na fila para pegá-los. Destes, quatro buscam outros títulos para compensar a ausência. De maneira geral, as obras selecionadas são diversas, ainda que se constate uma concentração maior daquelas que se enquadram no gênero aventura. No total, dez estudantes levam pelo menos um exemplar.

Renata, a garota que na quinta aula, assistida por Juliana, tinha levado três livros para casa, agora está com Estorias da Mitologia entre os selecionados. "Vou levar esse aqui, hoje, professor." "E você leu os outros?” “Claro que li. Um por semana. Primeiro O Ladrão de Raios, depois Deuses e Monstros da Mitologia Grega e, por último, Contos e Lendas da Mitologia Grega. Adorei, professor. E quando tiver algum outro do Percy Jackson disponível, não esquece de mim não, heim?”

É perceptível a influência que o filme exerceu sobre os alunos como estímulo à seleção de determinados títulos. Ou melhor, para a simples movimentação deles no sentido de fazer um empréstimo. E o que mais uma vez notamos é que esta aproximação não se dá necessariamente pelas obras que remetam de maneira muito específica ao filme. Ao contrário, a maior parte dos jovens se mostrou flexível em relação às opções disponíveis. Ainda que não tivesse o título que mais lhes interessava, verificou-se predisposição para um contato com o desconhecido.

De resto, cabe salientar a evolução de Renata no processo de leitura. Três aulas após a primeira experiência com livros de alguma forma associados a mitologia, a adolescente já estava em seu quarto empréstimo. E se considerarmos as quatro primeiras aulas em que acompanhamos as atividades em Sala de Leitura, o desenvolvimento é mesmo surpreendente, uma vez que em nenhuma delas Renata realizou um empréstimo.

\section{AULAS 9 E 10 - Excursão: aula livre e Festa junina: aula livre}

Optamos por unir a descrição das duas últimas aulas por duas razões. A primeira guarda relação com a atipicidade das duas aulas, em função de atividades que envolviam praticamente a escola inteira e reduziram o número de alunos em sala para, no mínimo, menos da metade. A segunda para evitar repetir mais uma vez observações já identificadas e verificadas como padrões de comportamento, 
como a utilização de equipamentos eletrônicos, as experiências musicais, os diálogos relacionados a produtos dos media, como séries de TV, filmes, jogos de futebol, novela, etc.

Neste sentido, para fechar o processo de descrição e análise ao qual havíamos nos proposto no início do presente capítulo, gostaríamos de resgatar um episódio em que os alunos, pela maior flexibilidade da aula, conversam longamente a respeito de videogames e computadores, inclusive com a participação do professor.

A sala, que durante essas aulas foi ocupada majoritariamente por meninos, inicialmente é tomada por diálogos a respeito de câmeras de vídeo, formas de captação de imagens, diferenças entre tecnologia HD e a comum e de como postálas em sítios como o Youtube. YouTube

Felipe faz uma explicação detalhada para Bruno, que obviamente tinha conhecimento básico do procedimento e das expressões utilizadas. "Os caras vendem a câmera e dizem pra você que é tecnologia HD, mas não explicam que a gente precisa tratar o arquivo. Eu acho isso uma sacanagem. Primeiro que você tem de ter um micro com processador bom. Quer dizer, se o cara compra a câmera, mas não tem micro, gasta uma puta grana pra ficar com um equipamento obsoleto. $\mathrm{E}$ mesmo assim, se você fizer um vídeo com mais de cinco minutos, as chances de dar pau na hora de renderizar é grande. Tem mais essa; pra renderizar também é um puta trampo. Não é que é difícil, mas demora, velho! Outro dia eu fiquei umas três horas pra tratar um videozinho ridículo.”

Em seguida, os garotos se deslocam para uma conversa sobre games. Primeiro falaram de segredos e comandos específicos para aplicar golpes em jogos de luta, fazer determinadas jogadas nos de futebol e encontrar portas escondidas nos que misturam ação e estratégia. Depois partiram para alguns jogos específicos. Dentre eles, o mais comentado foi God of War.

Mundialmente conhecido e inicialmente desenvolvido para o console Playstation 2, trata-se de um jogo lançado em 2005 e que em 2011 já está na quarta edição, dada a sua popularidade entre fãs de videogame. Na versão original, o protagonista é um guerreiro chamado Kratos, que, movido pela vingança, deseja destruir o Deus da Guerra, Ares. A aventura tem como tema central a mitologia e 
entre suas principais referências estão Atenas, a Caixa de Pandora, Poseidon, Zeus, Afrodite, Ártemis e Zeus.

Os alunos passam mais da metade da aula falando sobre capítulos do jogo, as dificuldades encontradas para enfrentar determinados desafios e as mais de quarenta horas necessárias para fechar o jogo. Em determinado momento, Ricardo fala de como foi difícil completá-lo. "Velho, eu ficava umas duas ou três horas por dia procurando na internet explicações, participava de fóruns de discussão. Minha mãe me enchia o saco porque eu vivia comprando as revistas que falavam sobre o jogo. No final, eu já não aguentava mais.”

Felipe lembra o quanto se sentiu frustrado ao ver Kratos abrir a Caixa de Pandora. “Quando ele encontra, a gente pensa que o jogo vai acabar. Eu fiquei pensando: mas já? Porque ela contém todos os poderes, né professor? Aí eu pensei, o cara vai ficar mais forte do que todos os deuses juntos. Mas aí Ares descobre e estraga a nossa brincadeira.”

À medida que o diálogo se desenvolve, percebemos que os alunos têm um bom conhecimento sobre o assunto. Graças ao jogo e à pesquisa desenvolvida para resolvê-lo, os estudantes sabem, por exemplo, quem são os deuses e as diferenças entre eles, que Atenas é uma cidade grega onde também viveram os filósofos, quem eram os titãs e como se deu o confronto com os deuses, e por aí vai.

O professor desconhecia o jogo, assim como os alunos também não haviam se servido do acervo da Sala de Leitura para fazer suas pesquisas. Mas quando questionados se gostavam de ler e quais livros tinham lido recentemente, a resposta foi um pouco previsível: Harry Potter, O Ladrão de Raios e O Senhor dos Anéis estavam entre os títulos preferidos. Também pudemos observar no grupo um interesse generalizado e bons conhecimentos em histórias em quadrinhos, RPG, desenho animado, informática e, de maneira mais ampla, equipamentos eletrônicos.

Sobre os diálogos acerca de captação de áudio e vídeo em HD, não poderíamos deixar de observar que tais aparatos são acompanhados de uma linguagem própria. Leigos no assunto que ouvem a conversa, não raro, têm dificuldade de compreender inclusive o sentido da frase. O número grande de palavras estrangeiras adaptadas ao nosso idioma reduz a capacidade do interlocutor menos preparado, especialmente se ele não tem contato com tais tecnologias. 
Resta-nos verificar se o desenvolvimento de tais linguagens pode atrair, afastar ou se revelar neutro quando o assunto é aproximar os jovens dos livros. Tendo em vista a complexidade destes processos, partimos do princípio de que a sua compreensão exige uma boa capacidade leitora. E mais uma vez voltamos a um dos princípios norteadores deste trabalho - a real abrangência e significado do termo leitura e, por consequência, o papel atribuído à Sala de Leitura. 


\section{CONCLUSÃO}

Meios de comunicação, livros e leitura. Ao refazermos o percurso proposto pela presente pesquisa, partimos da ideia bastante difundida de que os media afastam os jovens dos livros. Para os adeptos da Escola de Frankfurt, o principal efeito dos meios de comunicação é a alienação. Para os críticos da atualidade, eles são responsáveis por males como a perda da capacidade de memorização.

Em contrapartida a tais perspectivas, estabelecemos como objetivo principal deste trabalho verificar se tais aparatos e as mensagens veiculadas por eles são capazes de servir de recurso auxiliar das práticas educacionais. Baseando-nos em ideias como as de Martín-Barbero (2002), que nos classifica como membros de uma sociedade da educação, e passando também por Gómez Orozco (2004), que crê ser adequado considerá-la sociedade da aprendizagem, estabelecemos como aceitável a perspectiva que considera estarmos vivendo um processo de descentralização da educação. Neste sentido, transitamos de um modelo fundamentalmente definido pelos padrões clássicos para outro em que existem distintas fontes, muitas origens e parte delas sem relação direta com a educação formal.

Houve um tempo em que a missão dos professores era claramente definida e estava centrada no "ensinamento", na transmissão do conhecimento. A relação entre alunos e mestres parecia mais clara, com contornos nítidos. Cabia ao educador, o verdadeiro detentor do conhecimento, autoridade máxima, conduzir os educandos pelo caminho do saber.

As transformações econômicas e sociais do último século, aliadas às novas tecnologias de comunicação e informação, provocaram mudanças nesta relação. Percebeu-se que, além da escola, outros agentes colaboram com a produção e transmissão do conhecimento. E, tendo em vista que os estudantes passam mais tempo em relação direta com as telas e suas mais variadas manifestações (televisão, celular, internet, videogame...) do que em sala de aula, cabe a reflexão a respeito do potencial destas ferramentas, ou seja, questionar sobre sua real utilidade e que benefícios podem trazer. 
“Entendemos por descentramiento (J. Martín-Barbero/G.Rey, 1999) el conjunto de procesos y experiências(...) que testemonian la expandida circulacion por fuera del livro de saberes socialmente valiosos. De ellos hace parte la deslocalización que esos saberes presentan por relación a la escuela (entendiendo por ésta el sistema educativo en su conjunto desde la primaria hasta la universidad).” (MARTÍN-BARBERO, 2002)

Com base nesta mudança de olhar, nesta visão que considera os media como possíveis aliados, definimos como nosso objetivo de pesquisa identificar se os meios de comunicação podem contribuir para aproximar os jovens dos livros. Elegemos uma sala de leitura de uma escola municipal da cidade de São Paulo como espaço para a busca das respostas aos nossos anseios, considerando três elementos como premissas básicas para atingir tais objetivos.

Em primeiro lugar, entendemos que seria necessário verificar se estes produtos oriundos dos media de alguma maneira circulam no ambiente escolar. Neste sentido, seria fundamental que os alunos e, de preferência, também o professor, levassem para dentro da sala de leitura aquilo que eles ouvem, assistem, baixam, transmitem, arquivam, remetem, armazenam, renderizam, processam, conectam, sintonizam...

Em segundo lugar, e de maneira complementar, seria oportuno verificar se a escola, a Secretaria Municipal de Educação e a Prefeitura de São Paulo fornecem condições e infraestrutura para a circulação destes produtos dos media. Em outros termos, caberia observar se o projeto pedagógico admite tal configuração e se são fornecidos equipamentos e profissionais preparados para favorecer a manifestação deste cenário.

Em terceiro lugar, e principalmente, verificar se o trânsito destes discursos e produtos tinha o efeito conjeturado, isto é, se a partir de experiências concretas com os meios de comunicação, como um filme, uma música, uma série, os alunos têm o interesse despertado.

A metodologia escolhida para a realização do trabalho de campo foi a etnografia. Dada a abrangência dos objetivos da pesquisa, e o entendimento, desde 
o momento inicial, de que não caberia um recorte específico, que considerasse, por exemplo, um único meio de comunicação e/ou produto veiculado por ele, julgamos que os instrumentos de levantamento de dados fornecidos por esta proposta metodológica seriam os mais adequados.

Cabe lembrar que o grupo observado é composto de três turmas de $9^{\circ}$ ano, em um total de 97 alunos, além do professor da sala de leitura. O levantamento foi realizado ao longo de dez aulas, em um período de dois meses e meio, entre março e junho de 2011.

Dois instrumentos foram escolhidos para a captação dos dados: (1) a observação, que teve como sustentáculo, sobretudo, o diário de bordo, mas, de maneira complementar, a fotografia; (2) a pesquisa documental.

Considerados todos os pormenores até aqui descritos, quais sejam, o problema e os objetivos da pesquisa, a metodologia utilizada e os métodos de levantamento de dados, inicialmente refizemos a evolução histórica do programa Sala de Leitura, tendo como referência a legislação sobre o tema, com o propósito de verificar em que medida os projetos pedagógicos introduzidos pelos sucessivos governos, com ênfase especial na gestão atual, deram espaço para a utilização dos meios de comunicação como forma de leitura.

Verificamos, a partir do levantamento, dois paradigmas diferentes, implícitos na legislação nas diferentes gestões. Durante as administrações Erundina e Marta Suplicy, ocorre uma guinada favorável à introdução de suportes como o rádio, a televisão e o computador na sala de leitura, observada na adoção de expressões que classificavam o espaço como aquele onde são oferecidas “oportunidades de apropriação de informações com atividades diversificadas, envolvendo as múltiplas linguagens e favorecendo a memória das tradições e a geração de cultura".

Nas últimas duas gestões, Serra e Kassab, as expressões foram suprimidas da legislação que regulamenta e normatiza as Salas de Leitura. Por conta disso, podemos afirmar que, com relação à circulação dos produtos dos media, o programa sofre um retrocesso. Para os atuais condutores da política educacional, este espaço “visa precipuamente à inserção dos alunos na cultura escrita”.

De maneira objetiva, concluímos que, no momento da realização da presente pesquisa, o projeto pedagógico para as salas de leitura desfavorecia 
(ou pouco estimulava) a utilização dos meios de comunicação como forma de aproximar os estudantes dos livros.

Por outro lado, os equipamentos audiovisuais disponibilizados pela instituição e que poderiam de alguma forma facilitar o fluxo comunicacional estavam em condições básicas de uso. No transcorrer das dez aulas que acompanhamos, um kit composto por projetor de slides, aparelho de DVD e caixa de som foi doado para a escola e durante alguns encontros foi utilizado. Entretanto, conforme nos informou o professor de sala de leitura, ele teria recebido orientação para que o conjunto fosse guardado na sala da direção para evitar danificá-lo ou outras ocorrências, como furto.

Além disso, havia uma televisão de 29 polegadas e um aparelho de som portátil que não foram ligados durante as dez aulas e um aparelho de DVD danificado. Havia também uma pequena filmoteca com cerca de 20 títulos.

Podemos afirmar que as experiências vivenciadas na sala de aula nos permitiram colecionar uma série de elementos que comprovam a circulação dos produtos originários dos media na sala de leitura. Inicialmente imaginávamos que este diálogo intermediado ou participativo, que envolve programas de rádio e TV, filmes, sítios da internet e games, entre outros, se daria apenas no plano do discurso, ou seja, os alunos e até mesmo o professor levariam para dentro da escola o resultado de sua interface com os meios de comunicação e promoveriam um compartilhamento. Dito de outra maneira, um filme assistido na noite anterior, um programa de auditório, um vídeo ou uma música baixados de determinado portal, um jogo recém-adquirido seriam introduzidos no ambiente escolar em forma de diálogo: “Ontem passou Hancock na TV”, “Você viu que a rua Taguá passou no Profissão Repórter?”, “Assisti ao vídeo do gordinho Zangief no YouTube”, “Baixei uma música nova do Luan Santana”, “Estou jogando God of War.”

Entretanto, constatamos que a difusão destes produtos ocorre também durante as aulas: Vinícius joga videogame, usa smartphone e laptop, a música de Lady Gaga é compartilhada via Bluetooth, edições da revista Billboard e Gloss, mensagens via celular, acesso a internet, filmes, etc.

Em todos os encontros, sem exceção, observamos tanto o diálogo quanto a difusão da comunicação veiculada pelos media. E estes processos de circulação e troca de informações se manifestaram de forma mais intensa nas conversas entre 
os alunos. Antes, durante e depois das aulas, lá estavam eles a comentar ou compartilhar alguma informação digital ou analógica.

O professor, por seu turno, também teve sua participação neste sentido.

Os filmes, as provocações durante sua exposição, por intermédio de perguntas feitas em relação, por exemplo, a alguma experiência midiática. “Alguém aqui assistiu Tróia?” Mas, por outro lado, não foram poucos os episódios em que ele não estimulou a disseminação ou, ainda, atuou como cerceador de certo conteúdo aos quais os alunos tiveram acesso. Os casos em que ele pedia para desligarem aparelhos eletrônicos ou simplesmente descontinuava comentários feitos pelos estudantes atestam este argumento.

No que diz respeito aos aparelhos eletrônicos, julgamos conveniente fazer uma consideração: a princípio, o ideal é que outros estímulos não desviem o foco das aulas e, portanto, é correta a atitude do educador ao proibir que os estudantes joguem, acessem ou dialoguem por meio de seus aparatos tecnológicos. Entretanto, levando-se em consideração a flexibilidade que deveria caracterizar este espaço de leitura, entendemos que tentar estabelecer, em algumas ocasiões, contato com estas vivências dos alunos seria oportuno para incentivar, compreender e interagir com a citada circulação da informação.

Por fim, identificamos que os produtos dos meios de comunicação podem sim permitir a aproximação dos alunos em relação aos livros. Em primeiro lugar, vale citar que entre os campeões de empréstimos estão os títulos que foram adaptados para o cinema (Harry Potter, Crepúsculo, Percy Jackson...), com médias de permanência em poder dos alunos muito superior ao do restante do acervo $(9,25$ semanas contra 0,68). Em segundo lugar, há situações de leitura, de debates sobre leitura e de empréstimos de livros estimulados pela experiência com os media. Nas aulas três e oito, por exemplo, que tiveram exibição de filmes, houve o maior número de debates e mais livros foram solicitados.

Podemos resgatar, também, o quinto encontro, quando o professor falou especificamente sobre o herói e suas características. Ao retratar personagens dos quadrinhos, bem como da mitologia, muitos foram os apartes e colocações. Ocorre que os dois temas têm sido amplamente apresentados pelos meios de comunicação, em formato de HQ, filmes, desenho animado, games e, é claro, de livro. 
Há ainda os episódios em que os filmes Entrevista com o Vampiro e Sherlock Holmes tiveram papel determinante na seleção de livros para empréstimo. Isso sem contar as longas conversas sobre God of War, que revelou profundos conhecedores da mitologia, iniciados a partir do videogame, com migrações para outras plataformas nas quais estão incluídas a internet, a história em quadrinhos, o desenho animado e os livros.

Diante destas constatações, faz-se necessário ampliar as reflexões aqui iniciadas, preferencialmente a partir de direcionamentos mais específicos. Em nossa opinião, tais estudos são apenas constatações parciais acerca do potencial existente nestes aparatos, nas linguagens que os caracterizam e nos produtos que deles resultam. Incorporados à cultura da sociedade atual e, de maneira particular, à dos jovens, correspondem às suas expectativas e trazem à tona conteúdos que se convertem em conhecimento.

Como afirma Gómez Orozco, não parece razoável competir com eles e, neste sentido, talvez possa estar reservada ao professor uma posição estratégica de mediador. Ao ampliar sua visão para além das propostas curriculares, ele se deslocaria de uma condição tradicional, em que atua como transmissor do conhecimento, para outra na qual se converte em orientador, que auxilia, conduz e norteia, ao mesmo tempo em que também estimula o desenvolvimento de um espírito crítico nestas jovens audiências.

“A escola precisa começar a ver que fora dela há uma série de situações e fenômenos novos dos quais poderia participar, contribuindo com todo o seu potencial educativo e reflexivo. Tal postura vem ao encontro de seus próprios objetivos educacionais. (...) a inclusão da escola no desenvolvimento da tecnologia da comunicação é tão importante para a educação como para a sociedade como um todo.” (2006:375)

Há neste entendimento dois elementos que julgamos primordiais para que as novas demandas educacionais possam ser atendidas. De um lado, não recair em erro adotando soluções simplistas, motivadas pelo que se convencionou chamar de capacitação. Não vislumbramos receitas e métodos, passíveis de apostilamentos e 
sistematização em horas de treinamento, que atualizem satisfatoriamente professores das salas de leitura acerca das práticas comunicacionais. Como afirmamos nas considerações finais da aula seis, é importante compreender que levar elementos da cultura dos alunos, os quais passam pelos meios de comunicação, para dentro da sala de aula não significa realizar um simples recorte e trazer para o centro da discussão uma música, um programa, um filme, uma série, um game... sem considerar o contexto em que ele está inserido, sem compreendê-lo, sem experimentá-lo. E aqui voltamos a uma das questões-chave: não podemos nos esquecer que os professores também fazem parte de determinado extrato social, com suas particularidades, expectativas e interesses, de maneira que a imersão e o intercâmbio, a experimentação e a apropriação nunca serão completos se os interesses dos atores envolvidos (professores e alunos) forem distintos.

O segundo aspecto a ser considerado é a importância de ampliarmos o conceito de leitura. Talvez o papel deste espaço denominado Sala de Leitura deva ser admitido como o lugar das práticas leitoras, que transcende a palavra impressa, para estimular o olhar criterioso, cuidadoso e interessado sobre outras linguagens. A Sala de Leitura seria, nesta perspectiva, não apenas o lugar para promover a aproximação dos livros, mas também do videogame, da TV, do rádio, da internet, como uma tentativa de alcançar uma leitura mais abrangente e completa, que representa um olhar para dentro de nós mesmos - de auto-reconhecimento -, mas que também é a tentativa de compreender e interpretar o que há lá fora.

"A leitura do mundo precede a leitura da palavra, daí que a posterior leitura desta não possa prescindir da continuidade da leitura daquele. Linguagem e realidade se prendem dinamicamente. A compreensão do texto a ser alcançado por sua leitura crítica implica a percepção das relações entre o texto e o contexto." (FREIRE, 1992:12)

Simpatizamos com as ideias de Freire a respeito da amplitude e do significado da leitura, que, antes da palavra, recai sobre o mundo. Este, que desde o século XX e de maneira mais intensa a partir dos primeiros anos do novo milênio, é cada vez mais digital, via satélite, fibra óptica, pixel, 3G, touch screen, high tech, nanotecnologia, sustentável, biodegradável, renovável... 


\section{REFERÊNCIA BIBLIOGRÁFICA}

ABREU, Márcia. Cultura letrada, literatura e leitura. São Paulo: Unesp, 2006.

ADORNO, Theodor W. A indústria cultural. In: COHN, G. (org.). Comunicação e indústria cultural. São Paulo: Nacional, 1971, págs. 287311.

. Educação e Emancipação. In: ADORNO, Theodor W. Educação e emancipação. São Paulo: Paz e Terra, $4^{\mathrm{a}}$ ed., 2006.

; HORKHEIMER, Max. O fetichismo na música e a regressão da audição. Coleção os Pensadores, São Paulo: Nova Cultural, 1999.

ALMEIDA, Rosângela Doin de. de. Método integral para o ensino de leitura e escrita: uma ação proposta de alfabetização com compreensão. São Paulo. Dissertação de Mestrado. Faculdade de Educação da Universidade de São Paulo - FE/USP, 1987.

AMORIN, Galeno. Os muitos retratos da leitura no Brasil. In: AMORIN, Galeno. Retratos da leitura no Brasil. São Paulo: Imprensa Oficial, 2008.

ANDRÉ, Marli Eliza D.A. Etnografia da prática escolar. Campinas: Papirus, 1995.

ANSARAH, Marília Gomes dos Reis. Lazer cultural nos centros urbanos. In: MELO, J.M. (org.). Anuário de inovações em comunicação. São Paulo. Escola de Comunicações e Artes da Universidade de São Paulo ECA/USP, 1989.

BAKHTIN, Mikhail. Problemas da Poética de Dostoiévski. São Paulo: Forense Universitária, $5^{\circ}$ ed., 2010.

BARBETTA, Pedro Alberto. Estatística aplicada às ciências sociais. Florianópolis: UFSC, $5^{\mathrm{a}}$ ed., 2002.

BAUERLEIN, Mark. The Dumbest Generation - How the digital age stupefies young Americans and jeopardizes our future. Nova Iorque: Penguin, 2008.

BAUMAN, Zygmunt. Entrevista sobre Educação. Desafios pedagógicos e modernidade líquida. Cadernos de Pesquisa, n. São Paulo, v. 39, n $^{\circ}$ 137, 2009, págs. 661-664.

BELO, André. História \& livro e leitura. Belo Horizonte: Autêntica, 2008.

BOLLE, Willi. A ideia de formação na modernidade. In: GUIRALDELLI JR., Paulo (Org.). Infância, escola e modernidade. São Paulo: Cortez, 1997. 
BOURDIEU, Pierre. Esboço de auto-análise. São Paulo: Companhia das Letras, $2^{\text {a }}$ ed., 2010.

; CHAMBOREDON, Jean-Claude; PASSERON, Jean-Claude. A profissão de sociólogo. Petrópolis: Vozes, 1999.

Pierre; CHARTIER, Roger. A leitura: uma prática cultural. In: CHARTIER, Roger (org.). Práticas da leitura. São Paulo: Estação Liberdade, $4^{\mathrm{a}}$ ed., 2009, págs. 231-253.

CANDIDO, Antonio. A literatura e a formação do homem. Remate de Males - Revista do Departamento de Teoria Literária, São Paulo, 1999, págs. 81-89.

CANCLINI, Néstor Garcia. A Cultura política: entre o midiático e o digital. MATRIZes, São Paulo, v. 2, nº 2, 2008, págs. 55-71.

2008. Leitores, espectadores e internautas. São Paulo: Iluminuras, Libros, pantallas y audiencias: qué está cambiando? Revista Comunicar, $\mathrm{n}^{\circ}$ 30, págs. 27-32.

- Culturas híbridas: estratégias para entrar e sair da modernidade. São Paulo: EDUSP, $4^{\mathrm{a}}$ ed., 2008.

CASTELLÓN, Lena; RIBEIRO, Erica. Livros, um negócio de R\$ 7,1 bilhões. Meio \& Mensagem, São Paulo, nº 1460, 2011, pág. 23.

CASTRO, Maria Luisa Urban de. Programa de leitura recreativa: efeito de dois procedimentos de treino com escolares de quarta série do primeiro grau. São Paulo. Dissertação de Mestrado. Instituto de Psicologia da Universidade de São Paulo - IP/USP, 1981.

CERVANTES, Miguel. O engenhoso fidalgo D. Quixote da Mancha - V. 1 e 2. São Paulo: Abril, 2010.

CHARTIER, Roger. Do livro à leitura. In: CHARTIER, Roger (org.). Práticas da leitura. São Paulo: Estação Liberdade, 4ª ed., 2009, págs. 77105.

CHIZZOTTI, Antonio. Pesquisa qualitativa em ciências humanas e sociais. Petrópolis: Vozes, $3^{\mathrm{a}}$ ed., 2010, págs. 65-76.

CITELLI, Adilson. Comunicação e educação - a linguagem em movimento. São Paulo: SENAC, $3^{\text {a }}$ ed., 2004. 
Adilson. Educação e mudanças: novos modos de conhecer. In: CITELLI, Adilson (org.) Outras linguagens na escola. São Paulo: Cortez, 2000, págs. 17-38.

. Comunicação e linguagem: diálogos, trânsitos e interditos. In: MATRIZes, São Paulo, v.2, nº 2, 2008, págs. 13-30.

2006.

. Palavras, meios de comunicação e educação. São Paulo: Cortez,

COSTA, Maria Cristina Castilho. A importância do método interpretativo nas pesquisas em comunicação. Revista Arte e Cultura da América Latina, São Paulo, v. VII, nº 1, 2000.

CRUZ, Juan. O professor aloprado. In: Folha de S. Paulo de 11 de maio de 2008, Caderno Mais! http://noticias.uol.com.br/blogs-colunas/colunas-donew-york-times/umberto-eco/2009/10/05/ult7202u8.jhtm, consultado em 2 de novembro de 2009.

DUSSEL, Inés. A transmissão cultural sitiada: as metamorfoses da cultura comum na escola. Caderno de Pesquisa, v. 39, nº 137, 2009.

ECO, Umberto. Os arquivos sobre Eco no mundo virtual. The New York Times, 5 de outubro de 2009. Disponível em: http://noticias.uol.com.br/blogs-colunas/colunas-do-new-york-

times/umberto-eco/2009/10/05/ult7202u8.jhtm. Consultado em 2 de novembro de 2009.

; CARRIÈRE, Jean-Claude. Não contem com o fim do livro. Rio de Janeiro: Record, 2009.

FAILLA, Zoara. Os jovens, leitura e inclusão. In: AMORIN, Galeno (Org.). Retratos da leitura no Brasil. São Paulo: Imprensa Oficial, 2008, págs. 95108.

FISCHER, Steve Roger. História da leitura. São Paulo: UNESP, 2006.

FREIRE, Paulo. A importância do ato de ler. In: FREIRE, Paulo. A importância do ato de ler. São Paulo: Cortez, 1992, págs. 11-24.

GOETHE, Johann Wolfgang Von. Os anos de aprendizagem de Wilhelm Meister. São Paulo: 34, 2009

GÓMEZ, Guilherme Orozco. Professores e meios de comunicação: desafios e estereótipos. Revista Comunicação e Educação. São Paulo, nº 10, 1997, págs. 57-68. 
De la enseñanza al aprendizaje: desordenamientos educativocomunicativos em los tiempos, escenarios y procesos de conocimiento. Revista Nómadas, Bogotá, nº 21, 2004.

. Os meios de comunicação de massa na era da Internet. São Paulo, Comunicação e Educação, São Paulo, nº 3, 2006.

Audiências y pantallas en América. Comunicar, Huelva, v. XV, nº 30, 2008, Pág. 10-13.

GONZÁLEZ, Luz Eugenia Aguilar. Estrategias de aprendizaje en recepción infantil. Revista Nómadas, Bogotá, n 21, 2004, págs. 128-136.

HAGUETTE, Teresa Maria Frota. Metodologias qualitativas na sociologia. Petrópolis: Vozes, $7^{\mathrm{a}}$ edição, 2000, págs. 63-105.

HALL, Stuart. Identidade cultural na pós-modernidade. Rio de Janeiro: DP\&A, 2006.

HOGGART, Richard. The uses of literacy. Londres: Penguin Modern Clasi, 2009.

HOLANDA, Sérgio Buarque de. Raízes do Brasil. São Paulo: Companhia das Letras, 1997, $3^{\mathrm{a}}$ edição.

HUSSEIN, Carmen Lúcia. Leitura crítica e criativa: teste de procedimentos de treino e generalização: um estudo com escolares da quinta série. São Paulo. Tese de Doutorado. Instituto de Psicologia da Universidade de São Paulo -IP/USP, 1982, 312 págs.

INSTITUTO NACIONAL DE ALFABETIZAÇÃO FUNCIONAL. Instituto Nacional de Alfabetização Funcional. Disponível em: http://www.ipm.org.br/ipmb_pagina.php?mpg=4.02.02.00.00\&ver=por . Acessado em 3 de julho de 2011.

JAUSS, Hans Robert. A história da literatura como provocação à teoria literária. São Paulo: Ática, 1994.

JOHNSON, Steven. Surpreendente! A televisão e o videogame nos tornam mais inteligentes. Rio de Janeiro: Elsevier, 2005.

JOLIBERT, Josette. Formando crianças leitoras - v. 1. Porto Alegre: Armed, 1994.

JOUVE, Vincent. O Vivido da Leitura. In: JOUVE, Vincent. A Leitura. São Paulo: UNESP, 2004, págs. 107-122.

JUNIOR, Otávio. O livreiro do alemão. São Paulo: Panda Books, 2011. 
LAJOLO, Marisa. Do mundo da leitura para a leitura do mundo. São Paulo: Ática, 2001.

LÈVY, Pierre. Cibercultura. São Paulo: Editora 34, 2ª edição, 2008.

MAGALHÃES, Maria Helena de Andrade, Leitura... da leitura na escola de primeiro grau. São Paulo. Tese de doutorado. Faculdade de Educação da Universidade de São Paulo - FE/USP, 1992.

MÁRTIN-BARBERO, Jésus. Novas visibilidades políticas da cidade e visibilidades narrativas da violência. MATRIZes, São Paulo, v. 1, nº 1, 2008, págs. 27-39.

Norma, 2002.

La educación desde la comunicación. Buenos Aires:

MATTELART, Armand; MATTELART, Michèle. História das teorias da comunicação. São Paulo: Loyola, 13ª ed., 2010.

MEDINA, Cremilda. Ciência e jornalismo - da herança positivista ao diálogo dos afetos. São Paulo: Summus Editorial, 2008.

MEIER, Bruno. Uma geração descobre o prazer de ler. Veja, São Paulo, $\mathrm{n}^{\circ}$ 20, 2011, págs. 99-108.

MENDES, Mônica Fátima Valenzi. Sala de leitura nas escolas da Rede Municipal de Ensino de São Paulo: uma inovação que resiste às descontinuidades políticas. São Paulo. Pontifícia da Universidade Católica de São Paulo - PUC/SP, 2006.

MEYER, Catherine (Org.). O livro negro da psicanálise. Rio de Janeiro: Civilização Brasileira, 2011.

MEYER, Marlyse. Folhetim - uma história. São Paulo: Companhia das Letras, 1996.

MURRAY, Janet H. Hamlet no holodeck: o futuro da narrativa no ciberespaço. São Paulo: UNESP, 2003.

NUNES, Natália. Vida e obra de Fiódor Mikháilovitch Dostoiévski. In: DOSTOIÉVSKI, Fiódor. Obra completa - volume I. Rio de Janeiro: Nova Aguilar, 2004, págs. 25-122.

OLIVEIRA, P.T. Livros didáticos de leitura e interesses de escolares em leitura: contribuição para o estudo da psicologia da leitura. São Paulo. Tese de Doutorado. Instituto de Psicologia da Universidade de São Paulo IP/USP, 1972. 
OSPINA, Willian. La decandencia de los dragones. Bogotá: Punto de lectura, 2002.

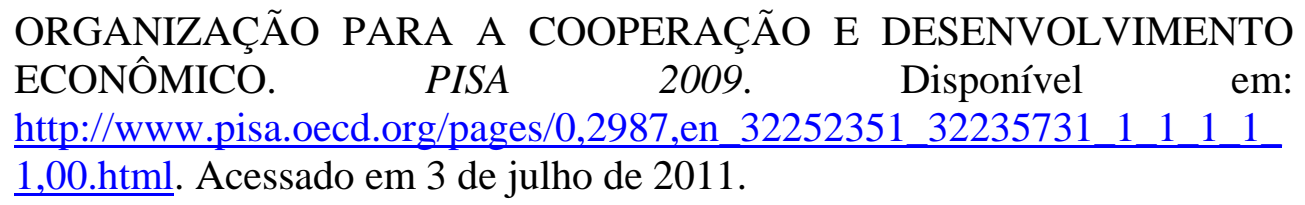

PEREZ, Isilda Lozano. Currículo, leitura, literatura - das possíveis leituras às muitas indagações: uma visão da Rede Municipal de Ensino de São Paulo. São Paulo. Dissertação de Mestrado. Faculdade de Educação da Universidade de São Paulo - FE/USP, 1990.

PERROTTI, Edmir. Leitor na cultura: a promoção a leitura infantil $e$ juvenil. São Paulo. Tese de Doutorado. Escola de Comunicações e Artes da Universidade de São Paulo - ECA/USP, 1989.

PETIT, Michèle. A arte de ler ou como resistir à adversidade. São Paulo: 34, 2009.

PIRANDELLO, Luigi. O falecido Mattia Pascal. São Paulo: Abril, 2010.

PIOVESAN, Laís Serafim Raso. Sala de leitura: atos, atores e ação. São Paulo. Escola de Comunicações e Artes da Universidade de São Paulo ECA/USP, 1999.

RAYMOND, Williams. Cultura. Paz e Terra, São Paulo, 2000.

REIMÃO, Sandra. Livros e televisão - correlações. São Paulo: Ateliê Editorial, 2004.

REZENDE, Neide Luzia de. Leitura literária na escola: para além da ficção midiática. In: CILENTO, A.Z.; INOCÊNCIO, D.; MASSON, T. J. Coleção licenciaturas em debate: ciência, ensino e aprendizagem - v.2. São Paulo: Plêiade, 2009, págs. 295-304.

ROCHA, Silvia Pimenta Velloso. Tornar-se quem se é: educação como formação, educação como transformação. In: MARTINS, A.M.M et alli. Nietzsche e os Gregos: Arte, Memória e Educação - V. Rio de Janeiro: DP\&A, 2006, págs. 267-278.

ROSAMILHA, Nelson. Atividades lúdicas e desenvolvimento da prontidão para a aprendizagem da leitura e escrita: implicações para a psicologia escolar. São Paulo. Tese de livre docência. Instituto de Psicologia da Universidade de São Paulo - IP/USP, 1978.

SOLÉ, Isabel. Estratégias de leitura. Porto Alegre: Artmed, 1998. 
SOUZA, José Carlos Cintra de. A Entoação e suas funções na leitura oral. São Paulo. Tese de Doutorado. Faculdade de Educação da Universidade de São Paulo - FE/USP, 1991.

SHILS, Edward. A sociedade de massa e a sua cultura. In: CALDAS, Waldenyr. Literatura da cultura de massa. São Paulo: Musa, 2000.

SECRETARIA MUNICIPAL DE EDUCAÇÃO. Programa Escola Biblioteca. São Paulo, nº 20, 1978.

SCHLINK, Bernhard. O leitor. Rio de Janeiro: Record, 2009.

SILVA,Tomaz Tadeu da. A "nova” direita e as transformações na política da pedagogia e na pedagogia da política. In: Silva, T. T.; GENTILI, P. (Org.). Neoliberalismo, qualidade total e educação. São Paulo: Vozes, 2001.

SMITH, Frank. Compreendendo a leitura: uma análise psicolingüística da leitura e do aprender a ler. Porto Alegre: artes Médicas, 1989.

SWINGEWOOD, Alan. O mito da cultura de massa. Rio de Janeiro: Interciência, 1978.

THIOLLENT, Michel J.M. Crítica metodológica, investigação social e enquete operária. São Paulo: Polis, $5^{\text {a }}$ ed., 1987.

TIOSSO, Lucia Helena. Percepção visual e aprendizagem da leitura e escrita. São Paulo. Tese de Doutorado. Instituto de Psicologia da Universidade de São Paulo - IP/USP, 1990.

TODOROV, Tzvetan. A literatura em perigo. Rio de Janeiro: DIFEL, $3^{\mathrm{a}}$ ed., 2010.

TOSCHI, Env. Percepção visual e aprendizagem da leitura e escrita. São Paulo. Tese de Doutorado. Instituto de Psicologia da Universidade de São Paulo - IP/USP, 1989.

WINKIN, Yves. A nova comunicação. São Paulo: Papirus, 1999, págs. 129155.

ZILBERMAN, Regina. A leitura e o ensino da literatura. São Paulo: Contexto, 1988. 